\title{
Revision of Leucothoe (Amphipoda, Crustacea) from the Southern Ocean: a cosmopolitanism concept is vanishing
}

\author{
Traudl KRAPP-SCHICKEL ${ }^{1}$ \& Claude DE BROYER ${ }^{2}$ \\ ${ }^{1}$ Zoologisches Forschungsmuseum A. Koenig, Adenauerallee 160, D-53113 Bonn, Germany \\ E-mail: traudl.krapp@uni-bonn.de (corresponding author) \\ ${ }^{2}$ Royal Belgian Institute of Natural Sciences, rue Vautier 29, B-1000 Bruxelles, Belgium \\ E-mail: claude.debroyer@naturalsciences.be \\ ${ }^{1}$ urn:1sid:zoobank.org:author:E1B1DCCF-04CB-4B1A-A69B-A7C25EC95A38 \\ ${ }^{2}$ urn:lsid:zoobank.org:author:970067BF-A792-48A9-B32A-B91F0E41C354
}

\begin{abstract}
Among the 125 currently recognized species of the panoceanic genus Leucothoe, L. antarctica was described in 1888 from the Antarctic seas, but was soon synonymized with the so-called cosmopolitan Leucothoe spinicarpa Abildgaard, which was cited from the Southern Ocean about 70 times since this first record. After erecting a new Antarctic species again only in 1983, "morphological variants" were observed and discussed. In this paper, we revalidate the first defined Antarctic species (Leucothoe antarctica), redescribe the second one (L. orkneyi), describe 5 new Southern Ocean species (L. campbelli sp. nov., L. longimembris sp. nov., L. macquariae sp. nov., L. merletta sp. nov. and L. weddellensis sp. nov.) and provide a key to all Antarctic and sub-Antarctic species.
\end{abstract}

Keywords. Crustacea, Amphipoda, Leucothoidae, Antarctica, Southern Ocean.

Krapp-Schickel T. \& De Broyer C. 2014. Revision of Leucothoe (Amphipoda, Crustacea) from the Southern Ocean: a cosmopolitanism concept is vanishing. European Journal of Taxonomy 80: 1-55. http://dx.doi.org/10.5852/ ejt.2014.80

\section{Introduction}

In the context of growing impact of environmental change on polar marine ecosystems (Turner et al. 2009; Verde \& di Prisco 2013), it appears crucial to establish comprehensive baseline information on the Antarctic marine biodiversity as a sound benchmark against which future change can reliably be assessed. The Census of Antarctic Marine Life programme (www.caml.aq) was partly set up to answer this need and organized several exploratory campaigns in various parts of the Southern Ocean (Gutt et al. 2010; Schiaparelli et al. 2013). This prompted the establishment of a comprehensive register of Antarctic marine species by a large panel of specialists (De Broyer \& Danis 2011).

In this framework, the revision of the amphipod crustacean fauna, one of the most species-rich taxa in Antarctic waters, was undertaken (De Broyer et al. 2007; Coleman 2007; Zeidler \& De Broyer 2009). Among the various amphipod families occurring in the Southern Ocean benthos, the composition of the Leucothoidae remains confused due in particular to the recurrent records of the so-called cosmopolitan 
species Leucothoe spinicarpa (Abildgaard, 1789) (see Lowry \& Bullock 1976; De Broyer et al. 2007). In the course of the revision of the Antarctic and sub-Antarctic amphipod fauna in the framework of the "Synopsis of the Amphipoda of the Southern Ocean", we revise here the Leucothoe Leach, 1814 material from some recent Southern Ocean collections.

\section{Material and Methods}

Complete specimens were studied in temporary glycerine slides, preparations made in Faure's fluid and both studied under various light microscopes. Pencil drawings were scanned in and 'inked' by applying the software Adobe Illustrator CS3 and Wacom tablets A4 and A5, using the method described in Coleman $(2003,2009)$. Examined specimens are stored in the various depositories mentioned in the material sections.

Geographic coordinates and depth data between square brackets are approximate and based on the SCAR ENEA Composite Gazetteer of Antarctica (http://www.scarmarbin.be/gazetteer.php?p=search) and the GEBCO map respectively (see detailed methods in De Broyer et al. 2007).

In this paper the following morphological terms are applied in the same way as in most of the earlier publications of the first author (see also Krapp-Schickel 2011: 2):

tooth $=$ non-articulated pointed ectodermal structure

spine = stout, articulated structure (synonymous to "robust seta" of Watling 1989)

seta $=$ slender, flexible articulated structure.

The length ratio between Gn dactylus and propodus is expressed by the shortest distance between the extreme ends of each.

\section{Abbreviations}

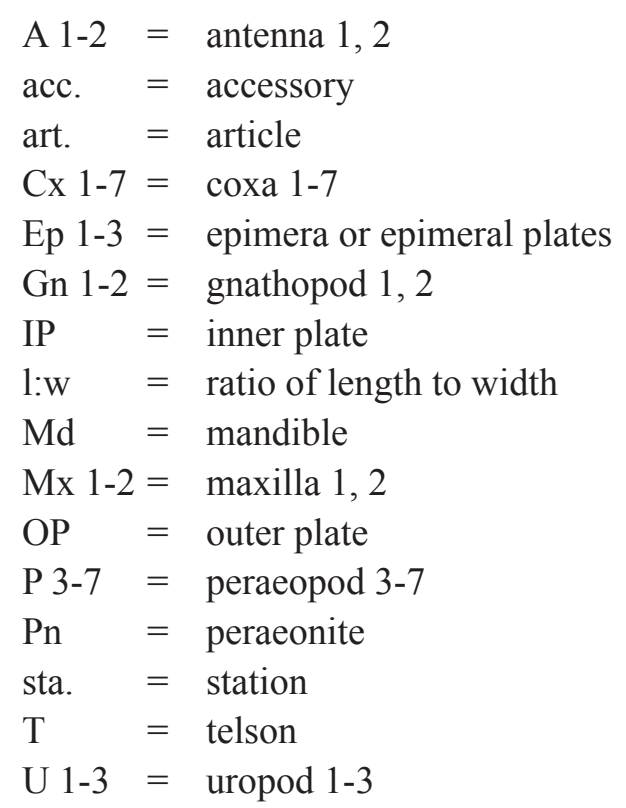

LPBO-UL $=$ Laboratory of Polar Biology and Oceanobiology, University of Łódź, Łódź, Poland. NIWA $=$ National Institute of Water and Atmospheric Research, Wellington, New Zealand.

RBINS $=$ Royal Belgian Institute of Natural Sciences, Brussels, Belgium. 


\title{
Results
}

\author{
Phylum Arthropoda von Siebold, 1848 \\ Subphylum Crustacea Brünnich, 1772 \\ Order Amphipoda Latreille, 1816 \\ Family Leucothoidae Dana, 1852
}

Genus Leucothoe Leach, 1814

\section{Type species}

Cancer articulosus Montagu, 1804.

\section{Remarks}

According to the World Register of Marine Species (WoRMS), the genus Leucothoe currently comprises no less than 125 species (Horton et al. 2013). The genus itself is morphologically very characteristic and easily recognized, but the distinction of the character states in the many species is usually quite difficult, as it is hard to realize what can be attributed to allometry, sexual diversity or intraspecific variability and what constitutes a stable specific morphological trait.

The first species recorded in the Southern Ocean, L. antarctica Pfeffer, 1888, was described by Pfeffer (1888) from the material collected in South Georgia, during the German International Year Expedition 1882-83. Della Valle (1893: 653) included, without comments, $L$. antarctica in his long list of $L$. spinicarpa synonyms, but Stebbing (1906: 168) kept it separate, noting that it "agrees generally with $L$. spinicarpa". Chilton (1912: 478), after checking the type-material, synonymized L. antarctica again with L. spinicarpa, regarded by Walker (1909) and subsequent workers as polymorphic and cosmopolitan (see K.H. Barnard, 1916: 148; Chilton 1921: 59, 1923: 85).

On the other hand, Walker (1907) first identified L. spinicarpa from the collections of the British National Antarctic Expedition 1901-1904 made at Winter Quarters Bay, Mc Murdo Sound, Ross Sea. Since this first record, L. spinicarpa has been found more than 68 times in the Southern Ocean s.l. (see complete detailed records in De Broyer et al. 2007, and on the SCAR-MarBIN/ANTABIF dataportal: http://data. biodiversity.aq/search_engine/es_search).

Analyzing in detail the material from the US Eltanin and Islas Orcadas cruises in the Scotia Sea and the Antarctic Peninsula regions, Holman \& Watling (1983) - after stressing that the "cosmopolitan" $L$. spinicarpa and related species have long been considered "a taxonomic headache" - distinguished three morphological variants of L. spinicarpa and described Leucothoe orkneyi Holman \& Watling, 1983.

In more recent years, the prevailing view has been to preserve full species status for most of the described Leucothoe species, at least until a more comprehensive taxonomic study has been undertaken (J.L. Barnard 1972: 137, 1974: 79).

The status of Leucothoe spinicarpa was recently revised by Krapp-Schickel \& Menioui (2005) who discussed the L. spinicarpa-group, re-established and redescribed some central Atlantic species formerly synonymized with $L$. spinicarpa, and by Crowe (2006), who designated a neotype and formally redescribed the species.

In this paper two already defined Antarctic species are redescribed and 5 additional ones presented as new for science. 
Key for Antarctic and sub-Antarctic Leucothoe-species:

1. Cx 2 and $\mathrm{Cx} 4$ anterodistally with acute angle [eyes yellowish].

L. merletta sp. nov. (2.5 mm, depth range unknown)

- Coxae anterodistally never acutely pointed

2. P 5-7 basis ratio 1:w clearly $>2$, proximally widest

L. longimembris sp. nov. (15 mm, depth: $1030 \mathrm{~m})$

- Basis P 5-7 ratio 1:w $<2$, medially widest

3. Gn 1 propodus and carpus distally very narrow and elongate, propodus ratio $1: \mathrm{w}>5$, dactylus $\leq 1 / 3$ of propodus length; Gn 2 propodus with palmar corner; peraeopod dactyli $>1 / 2$ length of propodus; Ep 2 posterodistally acutely lengthened [eyes small, compact and dark red] .................................... L. orkneyi Holman \& Watling, 1983 (4-9 mm, depth-range 11-1584 m)

- Gn 1 propodus ratio 1:w $\leq 5$, dactylus $\geq 1 / 3$ of propodus-length, Gn 2 propodus without palmar corner; peraeopod dactyli $\leq 1 / 2$ length of propodus

4. Gn 1 propodus robust, ratio $1: \mathrm{w}=3 \cdot 0-3.5$. [Cx 3 narrow with nearly parallel margins; P 5-7 basis ovoid, hind margin in $\mathrm{P} 7$ scarcely serrate, Ep 3 posterodistal corner minutely lengthened, posterior margin excavate]

L. macquariae sp. nov. (6-10 mm, depth-range 5-111 m)

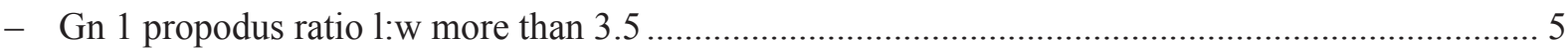

5. Gn 2 dactylus very long, reaching up to about $2 / 3$ of propodus length; Gn 1 propodus ratio 1:w $=5$; Ep 3 posterodistal corner rectangular L. campbelli sp. nov. (5-7 mm, depth-range 10-25 m)

- Gn 2 dactylus about half length of propodus or little more 6

6. P 7 basis regularly rounded, ratio length to width about 1.3. Eyes large, ommatidia separated

L antarctica Pfeffer, 1888 (4-9 mm, depth-range 24-335 m, doubtful material from $1584 \mathrm{~m}$ )

- P 7 basis ratio length to width about 1.7. Eyes large, ommatidia fused

L. weddellensis sp. nov. (10-24 $\mathrm{mm}$, depth range 9-602 m)

\section{Leucothoe antarctica Pfeffer, 1888}

Figs 1-5

Leucothoe antarctica Pfeffer, 1888: 54-57, Taf. II: fig. 4.

sub Leucothoe spinicarpa variant 3 - Holman \& Watling 1983: 228-229.

\section{Diagnosis}

Eyes large, round. Mandibular palp long and narrow, art. 3 about 1/3 length of art. 2. Cx 3 tongue-shaped rounded, smooth. Gn 1 propodus 1:w = 4-5, dactylus reaching about 1/3-1/4 of propodus length. P 5-7 basis oval broadened, with regularly rounded hind margin, ratio $1: \mathrm{w}=1.5$ to 1.2 ; posterior margin at least in P 7 strongly serrate (not mentioned in Pfeffer's description). Ep 2 posterodistally with rounded upturned corner.

\section{Type material}

Neotype 9 ov. 5 mm, 2 slides (RBINS, I.G. 31073 / INV. 103461). Polarstern ANT XIX/3 (ANDEEP

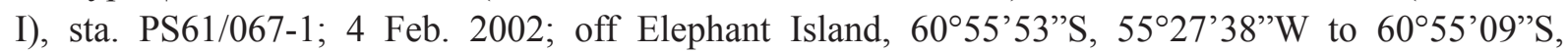
$55^{\circ} 24^{\prime} 50$ 'W; 115-182 m; bottom trawl. 


\section{Type locality}

South Georgia, Royal Bay, near the Deutsche Polarstation 1882-1883 at Moltke Harbor, approx. $54^{\circ} 30^{\prime} 58^{\prime} \mathrm{S}, 36^{\circ} 00^{\prime} 45^{\prime \prime} \mathrm{W}$.

\section{Additional material}

\section{Belgian-Dutch Antarctic Expeditions}

(RBINS, Brussels, EABN 1966-67, collectors: M. Steyaert \& M. Meisch, RBINS I.G. 23694)

EABN 1966-67, sta. 238, 3 Feb. 1967, Breid Bay, Baie Léopold, 70¹9’'S, 24¹4’E; 200 m; bottom trawl: 1 juv.

\section{Polarstern cruises}

(RBINS, Brussels, ANT XIII/3 (EASIZ I), coll. C. De Broyer \& G. Chapelle, RBINS I.G. 28252; ANT XIX/3 (ANDEEP I), coll. C. De Broyer, P. Dauby \& F. Nyssen, RBINS I.G. 31073)

ANT XIII/3 (EASIZ I), sta. PS39/24 MG26; 21 Feb. 1996; eastern Weddell Sea; 7108'06”S, 11³1'54’W; $118 \mathrm{~m}$; Multibox Corer: $1 \mathrm{spec} .3 .5 \mathrm{~mm}$.

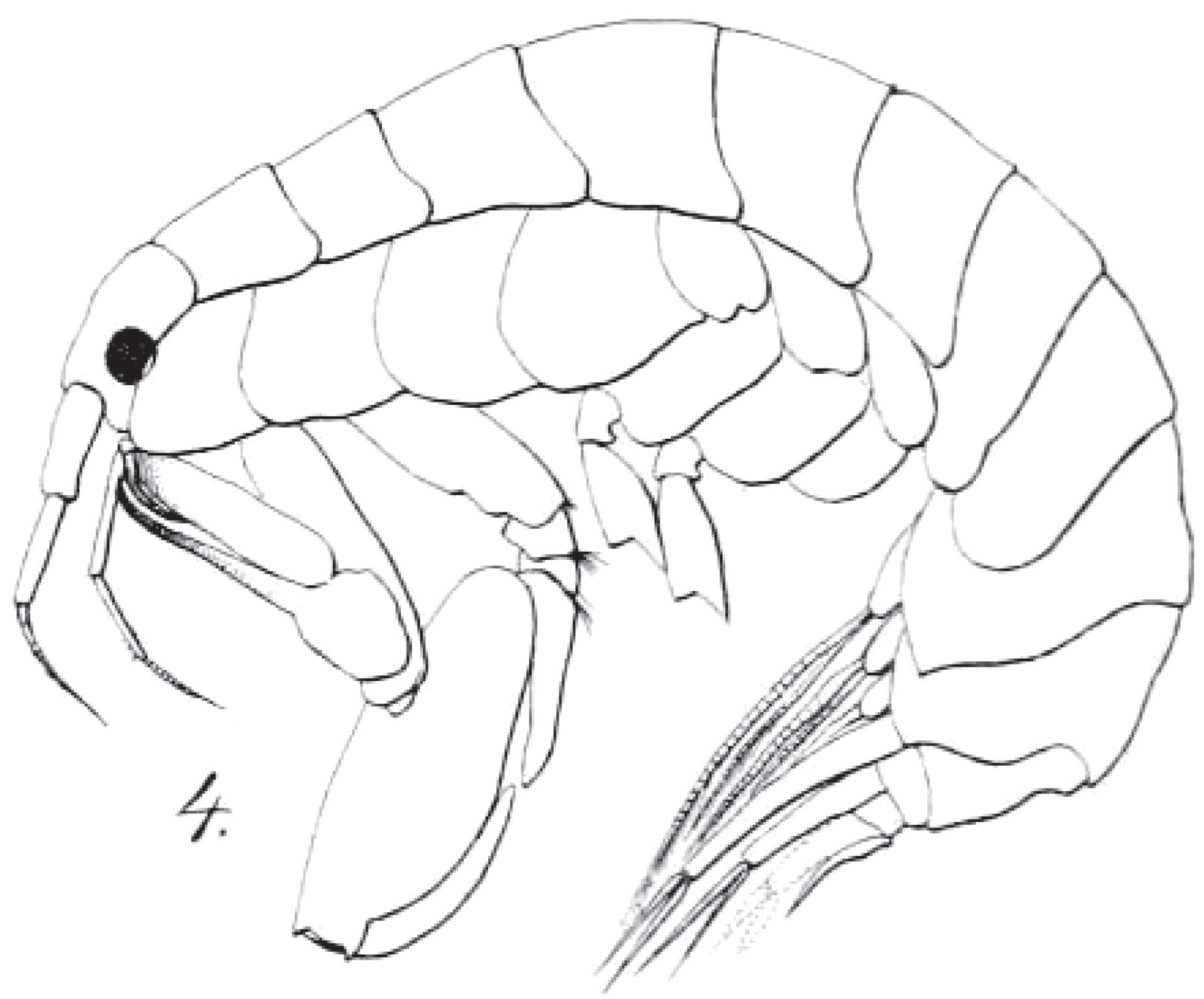

Fig. 1. Leucothoe antarctica Pfeffer, 1888: original illustration in Pfeffer 1888, fig. 4. 
ANT XIX/3 (ANDEEP I), sta. PS 61/047-1; 30 Jan. 2002; off Elephant Island; 614.18'S, 54³6.81'W, $189 \mathrm{~m}$, bottom trawl: 1 spec. $4 \mathrm{~mm}$.

ANT XIX/3 (ANDEEP I), sta. PS61/067-1; 4 Feb. 2002; off Elephant Island; 6055'53”S, 55²7’38”W to $60^{\circ} 55^{\prime} 09^{\prime}$ 'S, $55^{\circ} 24^{\prime} 50^{\prime \prime} \mathrm{W}$; $115-182 \mathrm{~m}$; bottom trawl: $1 \mathrm{spec}$. + ov. $5 \mathrm{~mm}$ slide.

\section{Polish Antarctic Expeditions (LPBO-UL, Lódź)}

$9^{\text {th }}$ Polish Ant. Exp, sta. OC 412; 11 Jan. 1985; King George Island, Admiralty Bay, Ezcurra Inlet ; $62^{\circ} 10^{\prime}$ S, 58 $32^{\prime}$ W; 90 m; Van Veen Grab: 1 spec.

$9^{\text {th }}$ Polish Ant. Exp, sta. OC 520; 3 Nov. 1985; King George Island, Admiralty Bay, section I; $62^{\circ} 09^{\prime} S$, $58^{\circ} 25^{\prime} \mathrm{W} ; 335$ m; Van Veen Grab: 1 juv.

\section{Victoria Museum, Melbourne}

? J 38267 [Aurora Australis AA93 142], off Mac Robertson Land, north of Fram Bank; 66 $48^{\circ}$ 46”S-6648'52”S, 70²4'59”E-70²5’32”E; depth: ? : 1 spec. $3 \mathrm{~mm}$.

\section{Redescription}

\section{Length}

4-9 mm [Pfeffer: "5 mm"].

\section{Head}

Anterior margin rounded, anterodistal margin rectangular with rounded corner. Mid-cephalic keel not prominent. Rostrum small.

Eyes large, round.

Antenna 1 a quarter of body length, flagellum 10-12-articulate, peduncle art. 1 width proximally less than twice article 2, disto-inferiorly without acute tooth, length art. 1 subequal art. 2, art. 3 about 1/4 of art. 2, acc. flagellum not seen.

Peduncle art. $3+$ flagellum shorter than peduncle arts $1+2$.

Antenna 2 subequal in length to antenna 1, peduncle art. $4>$ art. 5, flagellum 7-10 arts.

Mouthparts: Mandibles lacking molars, incisor and lacinia mobilis dentate; palp 3-articulate, art. 2 with 12 long lateral setae, art. 3 with 2 distal setae, 0.35 of art. 2. Maxilliped IP small, ventrally fused, OP reaching about $1 / 5$ of inner margin of palp art. 1; palp articles similar in length.

\section{Peraeon}

Cx 1 smooth, length > width; anterior margin smooth, facial setae absent, inferior margin smooth [Pfeffer: "anterodistally rounded corner of about $70^{\circ}$ "].

Gn 1 basis scarcely inflated, posterior margin with groups of short setae; ischium smooth; carpus basis more than half as long as propodus, distal part linear and extremely narrow, about $8 \mathrm{x}$ longer than wide; propodus straight, about 4-5 $\mathrm{x}$ as long as wide [Pfeffer: "about 4 times"], palm minutely dentate with 8 short setae; dactylus smooth, reaching about 1/3-1/4 propodus length.

Cx 2 subquadrangular, about as long as wide, much wider than $\mathrm{Cx} 3$, distally smooth; anterior margin straight, anterodistal corner rectangular, inferior and posterior margin straight, facial setae absent.

Gn 2 basis not inflated, on both margins up to 6 short or long setae; carpus nearly reaching half propodus length, curved, distally like a finger-tip rounded, densely setose; propodus anterodistally with short, 

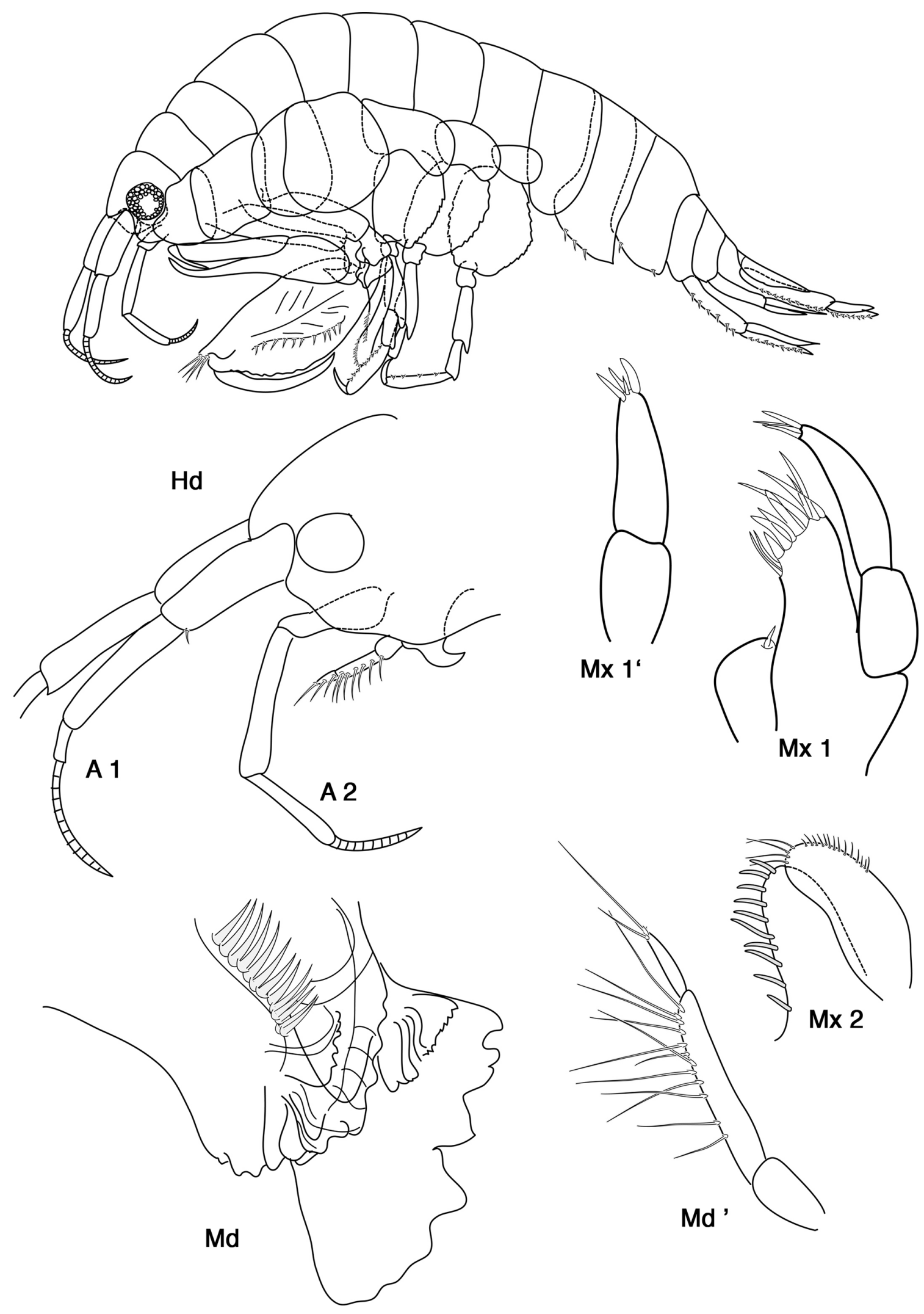

Fig. 2. Leucothoe antarctica Pfeffer, 1888, neotype $95 \mathrm{~mm}$. Hd = head; A 1, $2=$ antennae; $\mathrm{Mx} 1=$ first maxilla; Mx 1' = palp of first maxilla enlarged; Mx 2 = second maxilla; Md = mandible-body; $\mathrm{Md}^{\prime}=$ palp of mandible. 

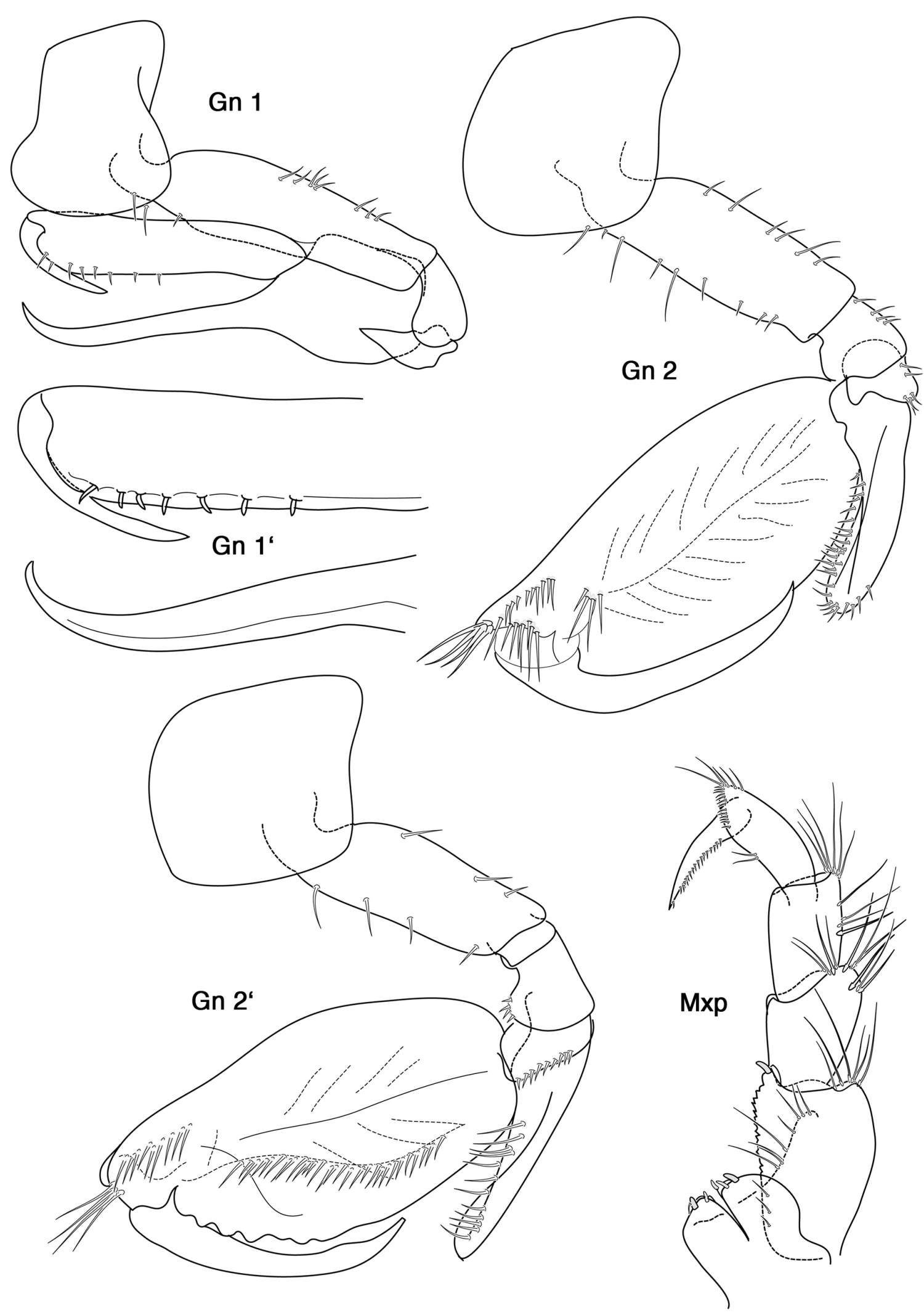

Fig. 3. Leucothoe antarctica Pfeffer, 1888, neotype $q 5 \mathrm{~mm}$. Gn $1=$ first gnathopod; Gn 1'= dactylus, propodus and carpus of first gnathopod enlarged; Gn 2 = second gnathopod female; Gn 2' = second gnathopod male; Mxp = maxilliped. 

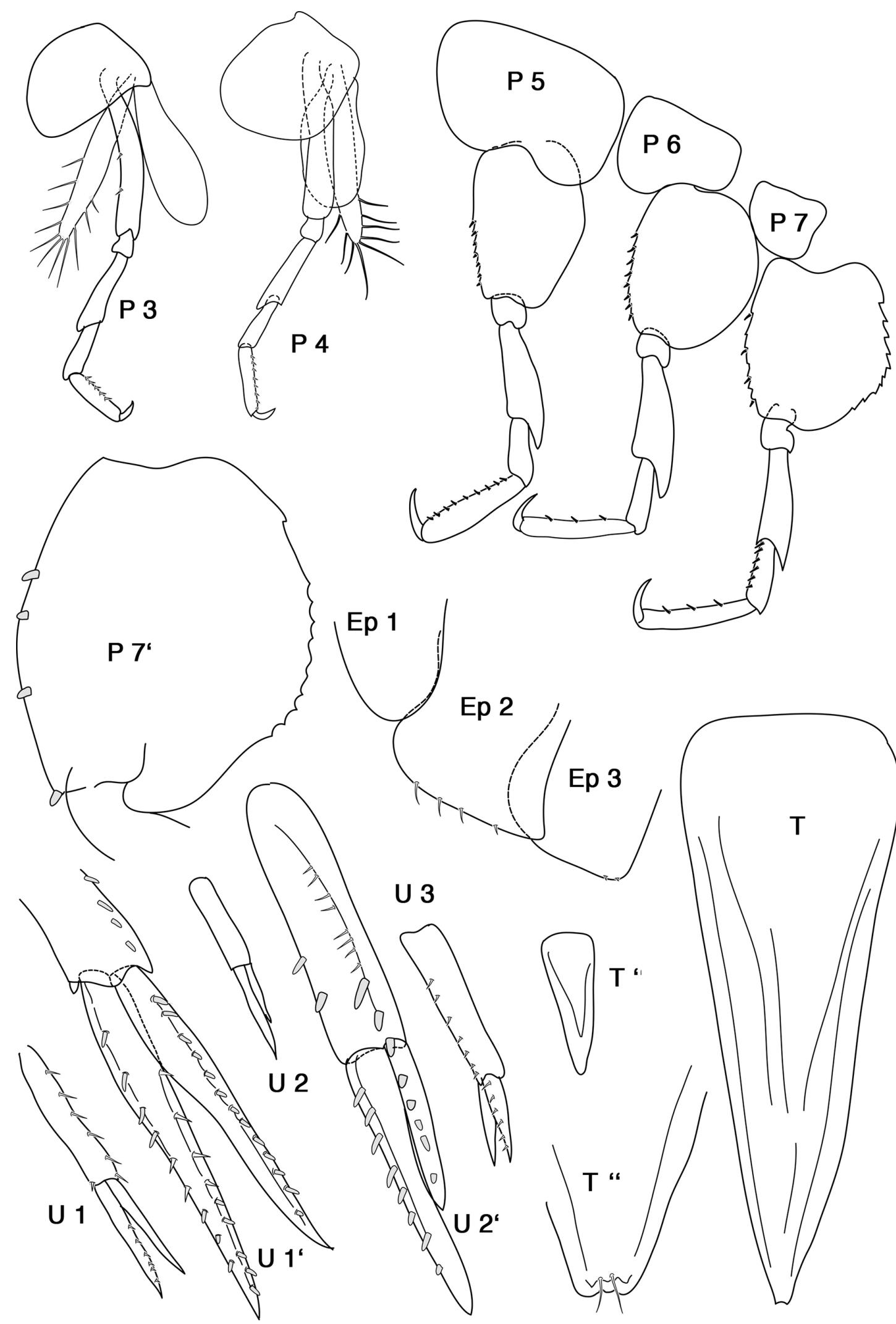
blunt prolongation and a bundle of setae, posterior margin with many low humps, palm convex, proximally near dactylus-end no corner; facial setae medially and submedially present; dactylus curved, both margins smooth, bare, reaching somewhat more than half of propodus length.

Cx 3 length $>$ width, anterior and posterior margin straight, distally rounded, smooth, facial setae absent.

Cx 4 length subequal to width or longer than wide, smooth, bare, anterior margin straight, distal margin rounded, posterior margin shorter than anterior one, not excavate, facial setae absent.

P 3, 4 basis very narrow, a bit wider than merus; dactylus reaching nearly half length of propodus, posterior margins with some short thin spines.

Cx 5-7 facial setae absent.

P 5-7 similar, bases 1:w ratio about 1.5 (P 5) to 1.2 (P 7), anterior margins with very slight serrations and small weak spines, posterior margins in P 5, 6 smooth or serrated, in P 7 strongly serrate [not mentioned in Pfeffer]. Merus in P 5-7 with posterodistal corner lengthened.

\section{Pleon}

Ep 2 with spines on distal margin, Ep 1, 3 distally bare, but some small setae on posterodistal corner of Ep 3. Ep 1 distally rounded, Ep 2 posteroventral corner not acutely upturned, but produced with rounded corner, Ep 3 posteroventral corner blunt and rectangular.

Uropods: U 2 the shortest, with very unequal rami (ratio nearly 1:2), the shorter one shorter than peduncle.

Telson ratio length:width $=3$, tip tridentate because of two indentations near distal end, with a short seta inserted in each one.

No sexual dimorphism known.

\section{Distribution}

Circum-Antarctic, from $54^{\circ}$ to $71^{\circ} \mathrm{S}$, from $11^{\circ}$ to $58^{\circ} \mathrm{W}$ and from 24 to $70^{\circ} \mathrm{E}$ (type material: $54^{\circ} \mathrm{S}, 36^{\circ} \mathrm{W}$ ).

\section{Depth range}

$24-335 \mathrm{~m}$.

\section{Remarks}

Pfeffer (1888) compared his new species only with the Atlantic species Leucothoe articulosa (Leach, 1814), insufficiently described and actually kept it - with question marks - as a synonym of $L$. spinicarpa (Abildbaard, 1789); there is, however, no doubt that it belongs to the "spinicarpa-group".

The original description and illustration of the single type are not very helpful (see Fig. 1), but at least the semicircular posterior margin of P 7 and the scarcely upturned rounded posterodistal corner in Ep 2 are visible in the drawing.

Holman \& Watling (1983: 228-229, fig. 11d-e) discussed a so-called "Leucothoe spinicarpa variant 3"; on p. 229 they wrote: " $\mathrm{Cx} 3$ with smoothly rounded ventral margin, $\mathrm{Cx} 4$ not excavate posteriorly. Gn 1 
dactyl 1/5 length and approximately equal to width of propodus, latter 6 times as long as wide (here 5x). P 7 basis broadly expanded, Ep 3 with quadrate posterodistal corner. Distribution: tip of Antarctic Peninsula, $210-220 \mathrm{~m}$ [about $63^{\circ} \mathrm{S}, 58^{\circ} \mathrm{W}$ ]."

By the combination of the key character states - P 7 basis broadly rounded, Gn 1 dactylus reaching about $1 / 4$ of propodus, Cx 3 distally smooth, Ep 2 posterodistal corner only a little produced and rounded L. antarctica clearly differs from all other members of the spinicarpa-group.

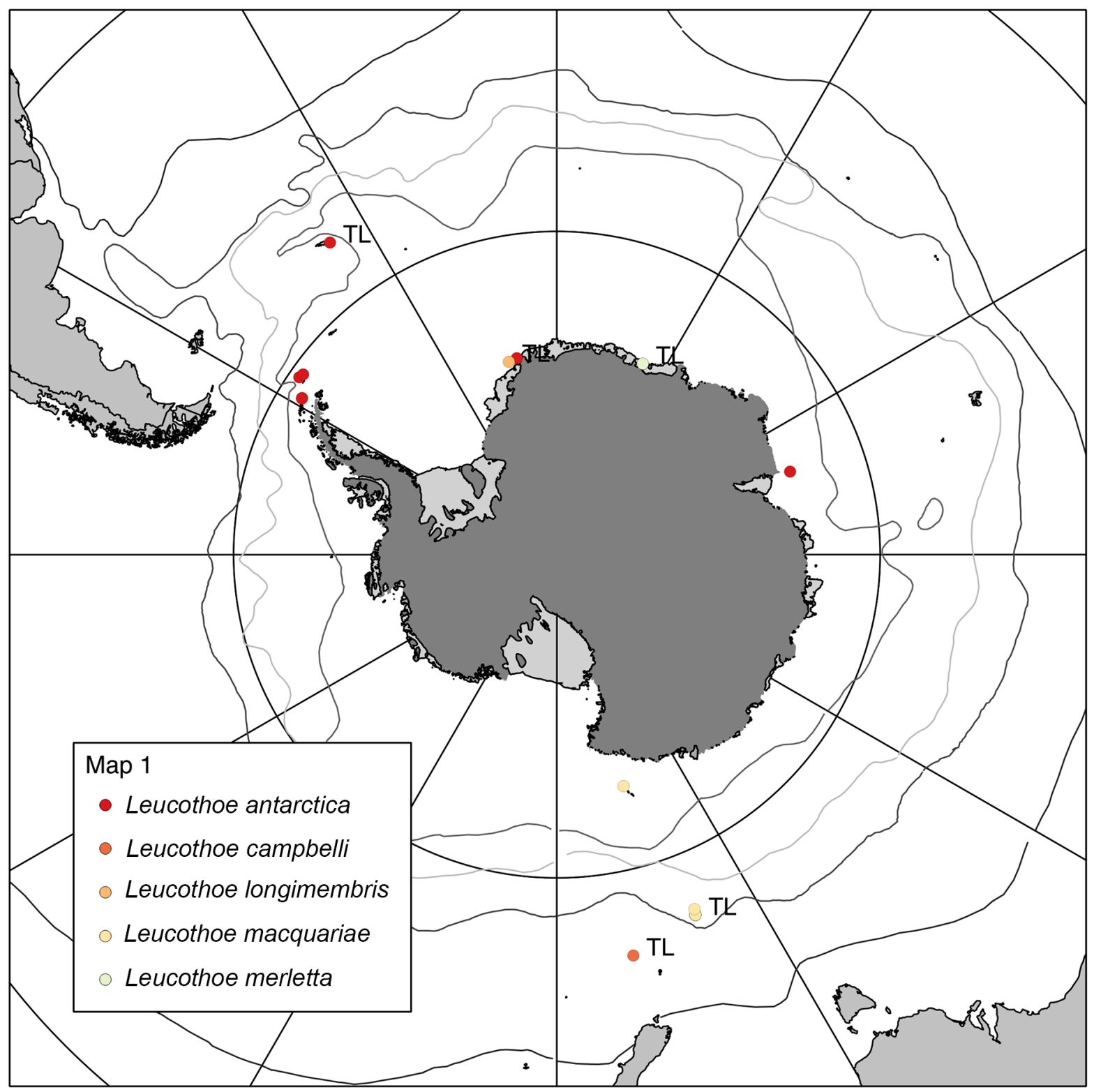

Fig. 5. Distribution of Leucothoe antarctica Pfeffer, 1888, L. campbelli sp. nov., L. longimembris sp. nov., L. macquariae sp. nov. and L. merletta sp. nov. The hydrographic fronts shown on the map are from north to south: the Sub-Tropical Front, the Sub-Antarctic Front, the Antarctic Polar Front and the Southern Antarctic Circumpolar Current Front. Mean position of the fronts according to Sokolov \& Rintoul (2009). TL = type locality. 


\section{Leucothoe campbelli sp. nov. urn:Isid:zoobank.org:act:21CA5E07-C2F3-4A9E-8412-85C8CBDA07C6}

Figs 5-7

sub Leucothoe spinicarpa variant 2 - Holman \& Watling 1983: 228, fig, 11a-c.

\section{Diagnosis}

Eyes large, round. Mandibular palp long and narrow, art. 3 1/2 length of art. 2. Cx 3 subtrapezoidal, ventrally smooth. Gn 1 propodus $1: \mathrm{w}=5$, dactylus reaching about $1 / 3$ of propodus length. $\mathrm{Gn} 2$ dactylus much longer than half length of propodus hind margin. P 5-7 basis oval, not much broadened, posterodistal corner lengthened, especially in $\mathrm{P} 7$, ratio 1:w $=1.66$; Ep 2 posterodistally with rounded upturned corner, posterior margin somewhat excavated near posterodistal corner. Ep 3 with right angled posterodistal corner. $\mathrm{T}$ l:w $=3$.

\section{Etymology}

The latinized adjective indicates the original locality of the new species.

\section{Type material}

Holotype ad. ? o $6.5 \mathrm{~mm}$, slide (Australian Museum, Sydney P. 80888); Southern Ocean, Campbell Island, Perseverance Harbour, cliff west of Davis Point: sta. CA 271; 7 Feb. $1980 ; 52.6^{\circ} \mathrm{S}, 169.2^{\circ} \mathrm{E}$; CA 271, 23 m depth; encrusting yellow sponge, larger sponges, barnacles and mussels, detritus and fine sediments.

\section{Additional material}

\section{Australian Museum, Sydney}

P. 80883: Southern Ocean, Campbell Island, Perseverance Harbour, west side of Davis Point; sta. CA 71; 1 Jan. $1980 ; 52.6^{\circ} \mathrm{S}, 169.2^{\circ} \mathrm{E} ; 16 \mathrm{~m}$ depth; sponges between boulders, barnacles and bryozoans from rock face: 3 spec. 3,6 and $7 \mathrm{~mm}$.

P. 80884: Southern Ocean, Campbell Island, Perseverance Harbour, west side of Davis Point; sta. CA 102; 4 Jan. $1980 ; 52.6^{\circ} \mathrm{S}, 169.2^{\circ} \mathrm{E} ; 25 \mathrm{~m}$ depth; sponges and tunicates, barnacles and bryozoans from rock face: 8 spec. $4-6 \mathrm{~mm}, 1$ o ov. $7 \mathrm{~mm}$.

P. 80885: Southern Ocean, Campbell Island, Perseverance Harbour, west side of Davis Point; sta. CA 105; 4 Jan. $1980 ; 52.6^{\circ} \mathrm{S}, 169.2^{\circ} \mathrm{E} ; 25 \mathrm{~m}$ depth; algae and sponges on mussels attached to boulders: 3 immat. 2.5, 3 and $4 \mathrm{~mm}$.

P. 80886: Southern Ocean, Campbell Island, Smoothwater Bay, cliffs West of East Cape; sta. CA 150; 13 Jan. $1980 ; 52.5^{\circ} \mathrm{S}, 169.2^{\circ} \mathrm{E} ; 18 \mathrm{~m}$ depth; holdfasts of Durvillaea antarctica (Chamisso) Hariot, sediment and red algae from rock crevice: 1 immat. $4 \mathrm{~mm}$.

P. 80887: Southern Ocean, Campbell Island, Smoothwater Bay, cliffs west of East Cape; sta. CA 154; 13 Jan. $1980 ; 52.6^{\circ} \mathrm{S}, 169.2^{\circ} \mathrm{E} ; 10 \mathrm{~m}$ depth; red algae and hydroids from crevices in rock face: 1 juv. $2.2 \mathrm{~mm}$.

P. 80888: Southern Ocean, Campbell Island, Perseverance Harbour, cliff west of Davis Point; sta. CA 271; 7 Feb. $1980 ; 52.6^{\circ} \mathrm{S}, 169.2^{\circ} \mathrm{E} ; 23 \mathrm{~m}$ depth; encrusting yellow sponge, larger sponges, barnacles and mussels, detritus and fine sediments: 6 spec. 5-6 mm.

P. 80889: Southern Ocean, Campbell Island, Perseverance Harbour, cliffs West of Davis Point; Sta. CA 273; 7 Feb. $1980 ; 52.6^{\circ} \mathrm{S}, 169.2^{\circ} \mathrm{E} ; 23 \mathrm{~m}$ depth; red algae and sponges from boulders and barnacles: 9 spec. 4-7 mm.

P. 80890: Southern Ocean, Campbell Island, Perseverance Harbour, cliff west of Davis Point; Sta. CA $276 ; 7$ Feb. $1980 ; 52.6^{\circ} \mathrm{S}, 169.2^{\circ} \mathrm{E} ; 23 \mathrm{~m}$ depth; sponge with yellow tubes and sediment from boulders: 3 immat. $3-4 \mathrm{~mm}$. 


\section{Description}

\section{Length}

5-7 mm.

\section{Head}

Anterior margin rounded, anterodistal margin rectangular with rounded corner. Mid-cephalic keel not prominent. Rostrum small.

Eyes large, round.

Antenna 1 one third of body length, flagellum 14-articulate, peduncle art. 1 width proximally less than twice article 2, disto-inferiorly without acute tooth, length art. 1 subequal to art. 2, art. 3 about 1/4 of art. 2, acc. flagellum not seen. Peduncle art. $3+$ flagellum about as long as peduncle arts $1+2$.

Antenna 2 subequal in length to antenna 1, peduncle art. $4>$ art. 5, flagellum 7-10 arts.

Mouthparts: Mandibles lacking molars, incisor and lacinia mobilis dentate; palp 3-articulate, art. 2 with 12 long lateral setae, art. 3 with 2 distal setae, art. 2 : art. $3=2$. Maxilliped IP small, ventrally fused, OP reaching about $1 / 3$ of inner margin of palp art. 1; palp articles similar in length.

\section{Peraeon}

Cx 1 smooth, length subequal to width; anterior margin smooth, facial setae absent, inferior margin smooth.

Gn 1 basis scarcely inflated, posterior margin with short setae; ischium with one seta; carpus basis more than half as long as propodus, distal part linear and narrow, about $10 \mathrm{x}$ longer than wide; propodus straight, about $5 \mathrm{x}$ as long as wide, palm with 7 short setae; dactylus smooth, reaching about $1 / 3$ propodus length.

Cx 2 wider than long, subrectangular, much wider than Cx 3, distally smooth; anterior margin rounded, anterodistal corner rectangular, inferior margin rounded, posterior one somewhat excavate, facial setae absent.

Gn 2 basis not inflated, both margins setose; carpus reaching about 1/3 propodus length, curved, distally blunt, densely setose; propodus anterodistally with blunt prolongation and one seta, posterior margin in adult male with many low humps, palm convex, proximally near dactylus-end no corner; facial setae medially and submedially present; dactylus curved, both margins smooth, bare, reaching somewhat more than $2 / 3$ of propodus length.

Cx 3 length > width, anterior and posterior margin slightly curved, distally scarcely rounded, smooth, facial setae absent.

Cx 4 length subequal to width or longer than wide, smooth, bare, anterior margin straight, distal margin rounded, posterior margin shorter than anterior one, not excavate, facial setae absent.

P 3, 4 basis very narrow, scarcely wider than merus; dactylus reaching about half length of propodus, posterior margins without spination.

Cx 5-7 facial setae absent. 


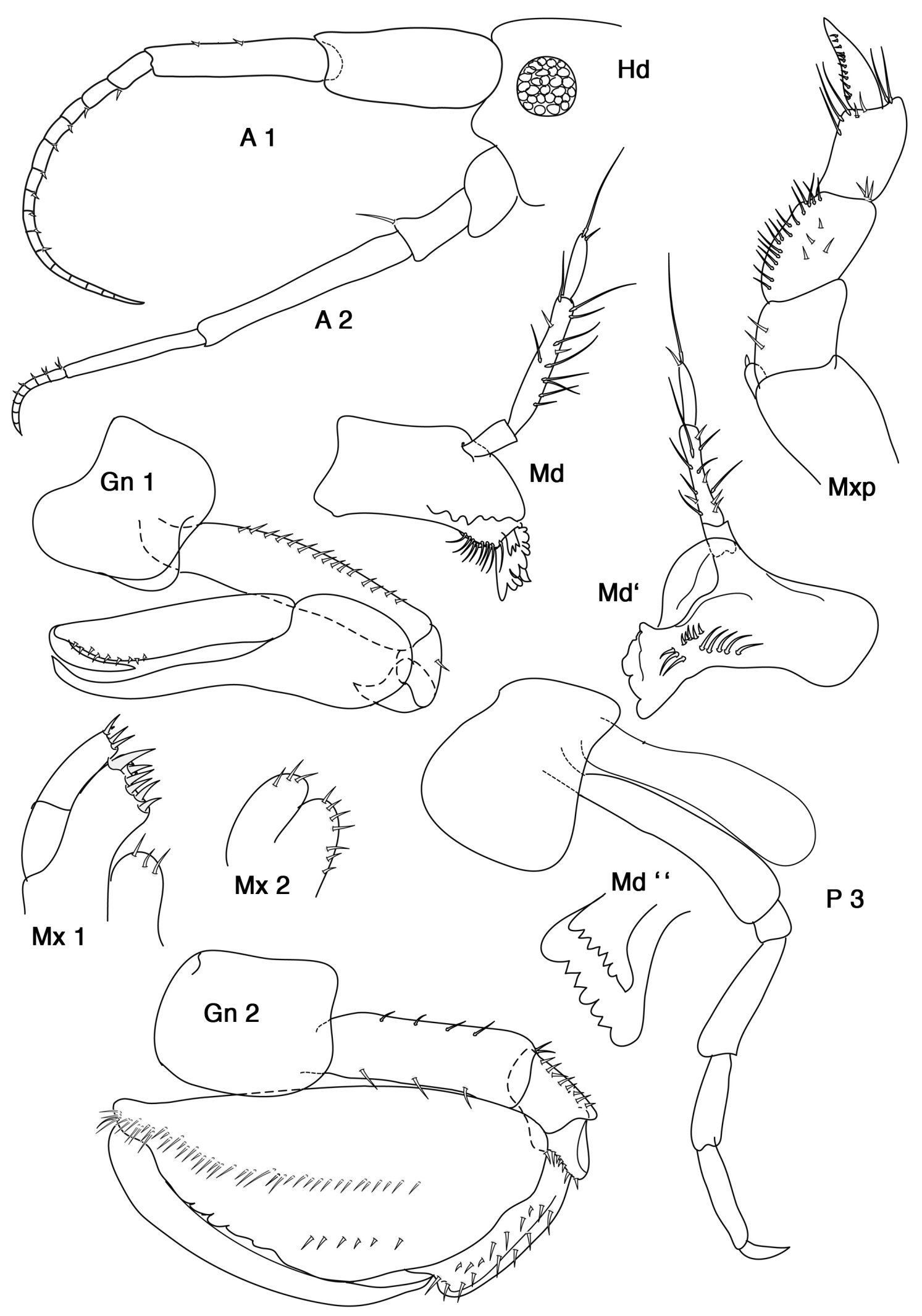

Fig. 6. Leucothoe campbelli sp. nov., holotype ?̊ $6.5 \mathrm{~mm}$. Hd = head; A 1, 2 = antennae 1, 2; $\mathrm{Md}, \mathrm{Md}^{\prime}=$ mandible from both sides; Md" = mandible partly enlarged; Mx 1, 2 = maxilla 1, 2; Mxp = maxilliped; Gn 1, 2 = gnathopod 1, 2. 


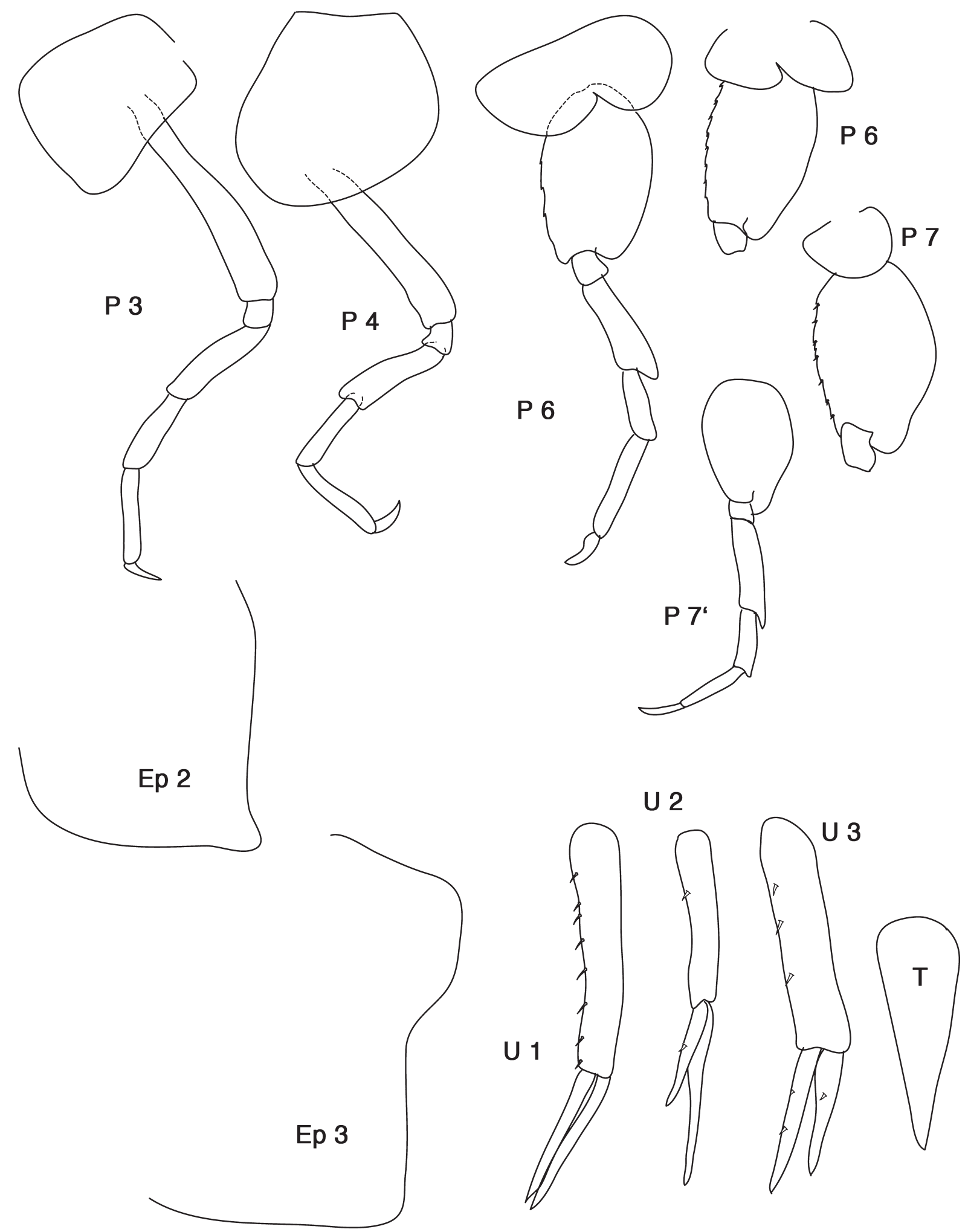

Fig. 7. Leucothoe campbelli sp. nov., holotype ?ð $6.5 \mathrm{~mm}$. P 3-7 = peraeopod 3-7; P 7' = peraeopod 7 reduced; Ep 2, 3 = epimeral plates 2, 3; U 1-3 = uropod 1-3; $\mathrm{T}=$ telson. 
P 5-7 similar, bases length:width ratio $=1.66$, anterior margins with very slight serrations and small weak spines, posterior margins smooth or slightly serrate. Merus in P 5-7 with posterodistal corner lengthened, basis in P 7 with characteristically lengthened posterodistal corner.

\section{Pleon}

Ep 1-3 posterodistally rounded, Ep 2 with lengthened rounded posteroventral corner and posterior margin slightly emarginate near corner, Ep 3 blunt-rectangular.

Uropods: U 1 rami subequal; $U 2$ the shortest, with very unequal rami (ratio about 1:2), the shorter one shorter than peduncle; $\mathrm{U} 3$ rami slightly unequal, both shorter than peduncle.

Telson ratio $1: \mathrm{w}=3$

No sexual dimorphism known.

\section{Distribution}

Campbell Island.

\section{Depth range}

$10-25 \mathrm{~m}$.

\section{Habitat}

Sponges, hydroids, tunicates, barnacles, bryozoans, holdfasts of Durvillaea antarctica, red algae and sediment.

\section{Remarks}

This species has gnathopods similar to the ones of the small specimens of L. weddellensis sp. nov., but the peraeopods are more robust and the posterodistal corners of Ep 2, 3 different; while the here described species lives in shallow depths, L. weddellensis sp. nov. was always found much deeper.

The species has the same ecology as L. macquariae sp. nov., but differs from the latter in Gn 1, 2 propodus, $\mathrm{P} 7$ basis and Ep 3.

Holman \& Watling (loc. cit.) described their "variant 2" as following:

"Coxa 3 with smoothly rounded ventral margin, coxa 4 not excavate posteriorly. Gnathopod 1 dactyl 1/4 length and slightly more than 1.5 times as wide as propodus, latter almost 7 times as wide. Third epimeron with quadrate posterodistal corner [...]. The first gnathopod has a considerably shorter dactyl than variant 1 [see L. weddellensis sp. nov. below], but appears similar to Sars' illustrations fo L. spinicarpa in most other respects. In stations where both variants 1 and 2 occurred, there is also a clear size dichotomy. Large specimens correspond consistently to variant 1 , while smaller ones correspond to variant 2 [...]. In addition, several variant 2 females were found to be ovigerous."

This text stresses how small the morphological differences are, but at the same time confirms the size differences of the ovigerous females.

The ecology, the quite shallow depth range as well as the shape of Gn 2 dactylus and Ep 2, 3 are good indications for this species. 


\section{Leucothoe longimembris sp. nov. urn:1sid:zoobank.org:act:935721E6-F9D5-4E0A-9AAD-5DEE628627EB}

Figs 5, 8-10

\section{Diagnosis}

A 1> A 2, eyes absent, Cx 1-5 all ending ventrally at about the same level. Basis P 5-7 slim, broadest not medially but proximally; both margins of bases weakly serrated. Ep 2, 3 posterodistal corner lengthened and pointed. $U 1$ rami subequal, $U 2$ rami unequal, ratio 2:1, $U 3$ rami subequal, about 2/3 of peduncle.

\section{Etymology}

Many articles (in Latin membrum, abl. plural membris) like antennae, Gn 1, but especially the bases of the peraeopods 5-7 are unusually elongated (= longis) and this character is different from all other species hitherto known from the Antarctic or sub-Antarctic regions. The chosen specific name is used as non-flexible apposition.

\section{Type material}

Holotype + ov. 15 mm (RBINS, I.G. 32565 / INV. 103462), Polarstern ANT XXII-3 (ANDEEP 3); sta. PS67/74-6 EBS; 20 Feb. 2005; eastern Weddell Sea; 71 $18.35^{\prime}$ 'S, $13^{\circ} 57.71^{\prime}$ W; 1030 m; epibenthic sledge; coll. C. De Broyer \& B. Danis.

\section{Description}

\section{Length}

$15 \mathrm{~mm}$.

\section{Head}

Anterior margin rounded, anterodistal margin rectangular with rounded corner. Mid-cephalic keel not prominent. Rostrum small.

Eyes absent.

Antenna 1 nearly half of body length, flagellum with 21 articles, peduncle art. 1 width proximally less than twice article 2, disto-inferiorly with acute tooth, length art. 1 subequal to art. 2, art. 3 about 1/4 of art. 2, acc. flagellum not seen. Peduncle art. $3+$ flagellum shorter than peduncle arts $1+2$.

Antenna 2 shorter than antenna 1, peduncle art. $4>$ art. 5 , flagellum 7 arts.

Mouthparts: Mandibles lacking molars, incisor and lacinia mobilis dentate; palp 3-articulate, art. 2 with many lateral setae of different length, art. 3 with 2 distal setae, more than half length of art. 2. Maxilliped IP small, fused, OP reaching about 1/5 of inner margin of palp art. 1; palp articles similar in length.

\section{Peraeon}

Cx 1 smooth, length > width; anterior margin smooth, facial setae absent, inferior margin smooth.

Gn 1 basis slender, not inflated, both margins with short setae; ischium smooth; carpus basis about half as long as propodus, distal part linear and extremely narrow, about $10 \mathrm{x}$ longer than wide; propodus straight, about $6 \mathrm{x}$ as long as wide, palm with short setae; dactylus smooth, reaching about 1/3 propodus length.

Cx 2 subquadrangular, about as long as wide, twice as wide as $\mathrm{Cx} 3$, distally smooth; anterior margin and anterodistal corner regularly rounded, inferior margin straight, posteriorly somewhat excavated, facial setae absent. 


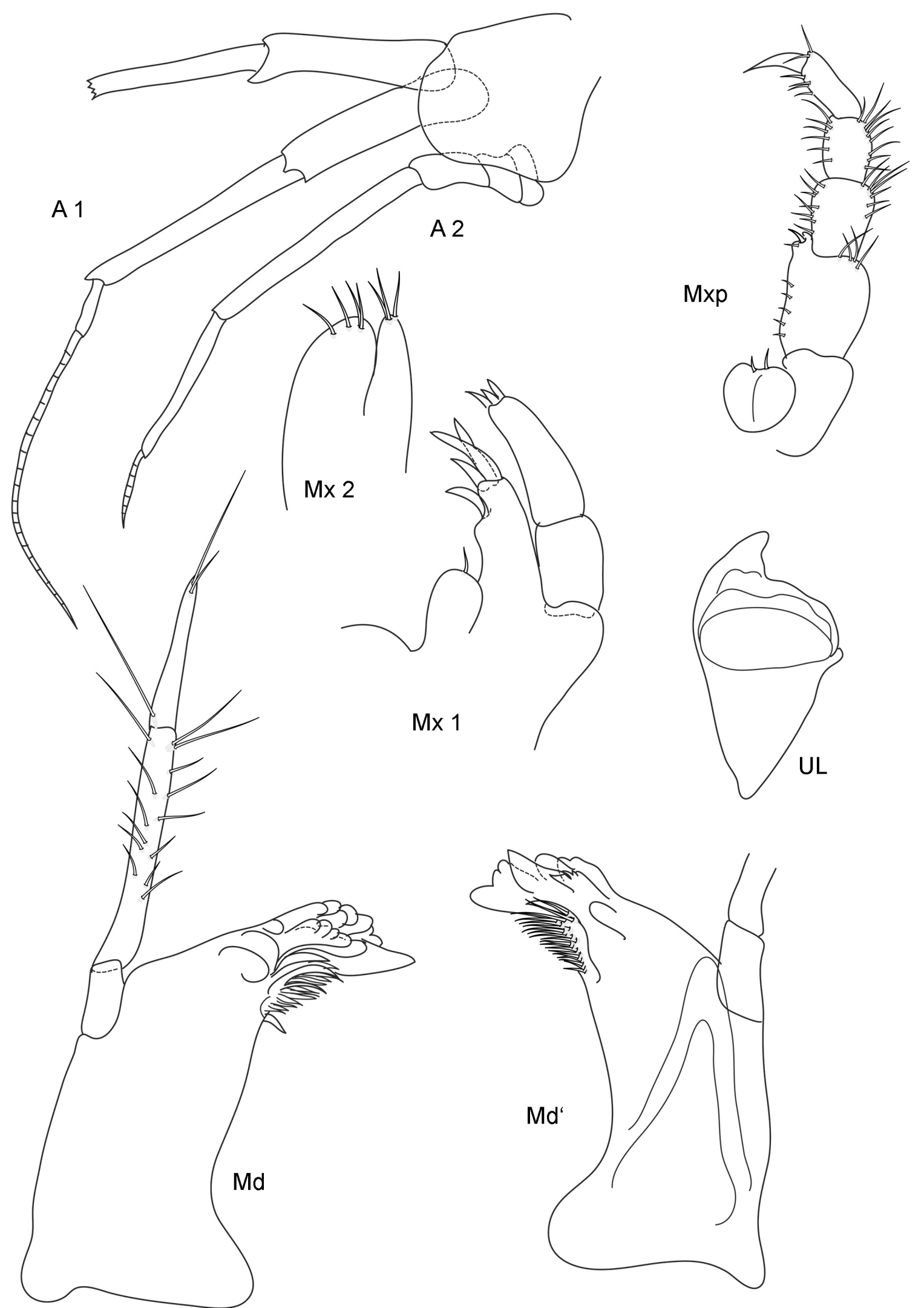

Fig. 8. Leucothoe longimembris sp. nov., holotype $\$ 15 \mathrm{~mm}$. A 1, $2=$ antenna 1, 2; UL = upper lip; Mx 1,2 = maxilla 1, 2; Md, Md' = mandible from both sides; Mxp = maxilliped. 


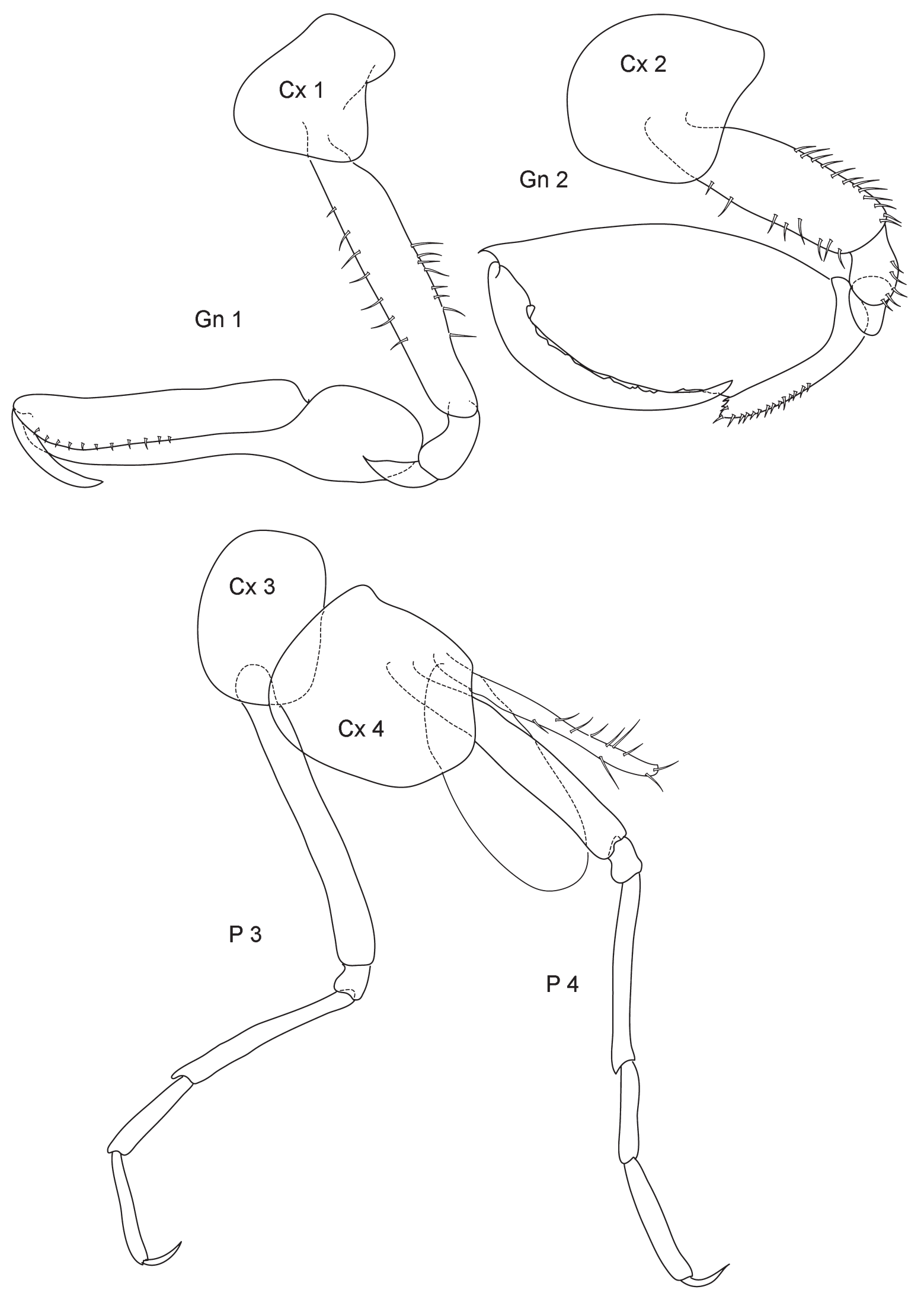

Fig. 9. Leucothoe longimembris sp. nov., holotype $\odot 15 \mathrm{~mm}$. Cx 1-4 = coxa 1-4; Gn 1, 2 = gnathopod 1,$2 ;$ P 3, 4 = peraeopod 3, 4 . 


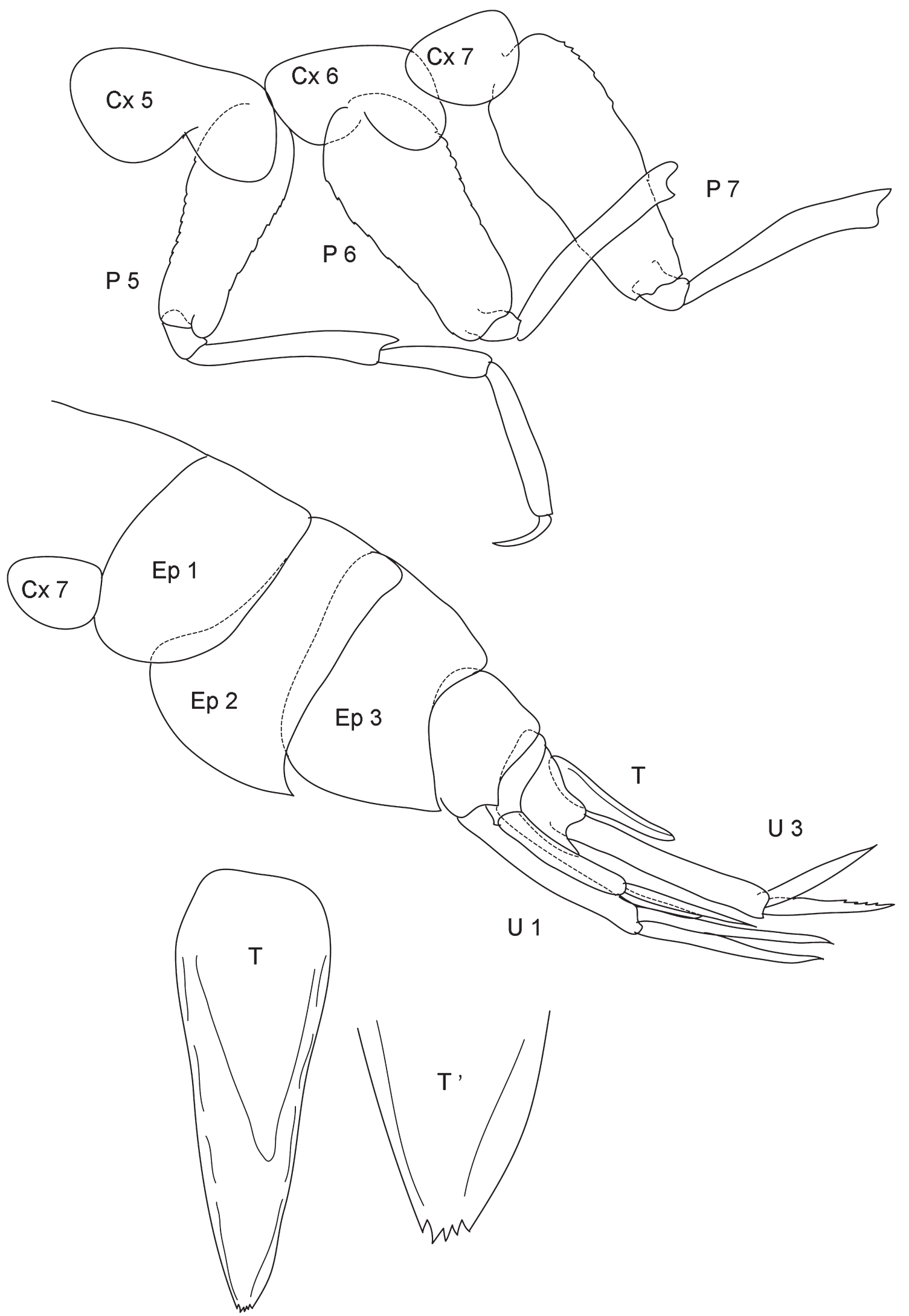

Fig. 10. Leucothoe longimembris sp. nov., holotype $+15 \mathrm{~mm}$. Cx 5-7 = coxa 5-7; P 5-7 = peraeopod 5-7; Ep 1-3 = epimeral plate 1-3; U 1, U $3=$ uropod 1, 3; T = telson; T' = telson distally enlarged. 
Gn 2 basis not inflated, on both margins short setae; carpus reaching about 1/3 propodus length, curved, distally serrated, setose; propodus anterodistally with short, acute prolongation, posterior margin with many low humps, palm convex, proximally near dactylus-end no corner; facial setae not seen; dactylus curved, both margins smooth, bare, reaching about $2 / 3$ of propodus length.

Cx 3 elongate, length > width, anterior margin rounded, posterior margin straight, distally rounded, smooth, facial setae absent.

Cx 4 length shorter than width, smooth, bare, anterior margin nearly straight, distal margin rounded, posterior margin shorter than anterior one, not excavate, facial setae absent.

P 3, 4 basis very narrow, wider than delicate merus; dactylus reaching nearly half length of propodus, all margins naked.

Cx 5-7 facial setae absent.

P 5-7 similar, bases length:width ratio about 2.5 (P 5), 2.3 (P 6) and 2.6 (P 7), both margins with very slight serrations. Merus in P 5-7 with posterodistal corner lengthened.

\section{Pleon}

Ep 1-3 bare. Ep 1 distally rounded, Ep 2, 3 posteroventral corner acutely upturned.

Uropods: U 2 the shortest, with very unequal rami (ratio about 1:2), the shorter one shorter than peduncle. $\mathrm{U} 1$ and $\mathrm{U} 3$ with subequal rami.

Telson ratio 1:w $=3$, tip five-dentate because of four indentations near distal end.

\section{Remarks}

The new blind species is similar to the (also blind) deep-sea species L. ayrtonia Bellan-Santini, 1997 $(5 \mathrm{~mm})$ and L. atosi Bellan-Santini, $2007(12 \mathrm{~mm})$, found in the Mid-Atlantic Ridge at $37^{\circ} \mathrm{N}, 31^{\circ} \mathrm{W}$ at a depth of $850 \mathrm{~m}$, and at the Barbados Trench, $10^{\circ} \mathrm{N}, 58^{\circ} \mathrm{W}$ at a depth of $1947 \mathrm{~m}$ respectively. Differences from L. ayrtonia are in the large rostrum, Cx 4 with posterodistal acute corner, Ep 3 quadrate with small tooth, from $L$. atosi are in much shorter antennae, blunt posterodistal corner at Ep 2, less unequal U 2 and broader telson. Also L. ushakovi Gurjanova, 1951 (type from Greenland at a depth of $3892 \mathrm{~m}$, specimens from 8-34 mm length; see Krapp-Schickel \& Vader 2012) has P 5-7 bases not medially, but proximally widest and is blind; differences with L. longimembris are are the setose bases of Gn 1, 2 and very unequal rami in $\mathrm{U} 2$ in the here described material (vs. naked bases and less unequal rami in $L$. ushakovi), a longer Gn 1 dactylus and a five-dentate slender telson here (vs. short dactylus and threedentate broader telson in L. ushakovi).

Leucothoe macquariae sp. nov.

urn:1sid:zoobank.org:act:6D484A0D-EC95-4D53-9C12-2E00B6A90F42

Figs 5, 11-12

\section{Diagnosis}

Eyes large, round. Cephalic keel not prominent. Mandibular palp art. 3 equal to longer than $1 / 2$ length of art. 2. Gn 1 propodus 1:b =3-3.5, dactylus reaching nearly $1 / 2$ of propodus length. P 5-7 basis oval broadened, with regularly rounded hind margin, ratio length to width 1.7 to 1.3 ; posterior margin in P 7 weakly serrate. Ep 3 posterodistally with rounded upturned corner. U 3 robust, rami somewhat unequal. $\mathrm{T} 1: \mathrm{w}<3$. 


\section{Etymology}

The latinized adjective refers to the type locality.

\section{Type material}

Holotype $\widehat{0} 7.5 \mathrm{~mm}$ in alcohol (Australian Museum, Sydney: P. 81138); Southern Ocean, Macquarie Island, Tottan Head, south end of Goat Bay; sta. MA 375; 30 Jan. 1978; $54.49167^{\circ} \mathrm{S}, 158.9625^{\circ} \mathrm{E} ; 14 \mathrm{~m}$ depth; encrusting sponge, hydroid and tunicate mat on vertical wall of offshore rock.

\section{Additional material}

\section{Australian Museum, Sydney}

P. 80891: Southern Ocean, Macquarie Island, Garden Bay, near Hayter Rock; sta. MA 17; 23 Nov. 1977; $54.5^{\circ} \mathrm{S}, 159^{\circ} \mathrm{E} ; 10 \mathrm{~m}$ depth; Macrocystis pyrifera (L.) Agardh holdfasts: 1 spec. immat. $4 \mathrm{~mm}$.

P. 80892: Southern Ocean, Macquarie Island, Tottan Head, south end of Goat Bay; sta. MA 41; 30 Nov. $1977 ; 54.49167^{\circ} \mathrm{S}, 158.9625^{\circ} \mathrm{E} ; 14 \mathrm{~m}$ depth; sponges, bryozoans and colonial tunicates from vertical rock wall of offshore rock: 3 spec. 6-7 mm.

P. 80893: Southern Ocean, Macquarie Island, Garden Bay; sta. MA 87; 7 Dec. 1977; 54.5 $\mathrm{S}, 159^{\circ} \mathrm{E} ; 8 \mathrm{~m}$ depth; Macrocystis pyrifera holdfasts and sponges: $1 \mathrm{spec}$. immat. $3 \mathrm{~mm}$.

P. 81121: Southern Ocean, Macquarie Island, Aerial Cove; sta. MA 108; 12 Dec. 1977; 54.5 ${ }^{\circ} \mathrm{S}, 159^{\circ} \mathrm{E} ; 5 \mathrm{~m}$ depth; sponges and bryozoans from sheltered base of vertical rock face: $11 \mathrm{spec} .3-6 \mathrm{~mm}, 1 \mathrm{spec} .8 \mathrm{~mm}$.

P. 81122: Southern Ocean, Macquarie Island, rocks off end of Garden Bay Peninsula; sta. MA 123; 16 Dec. $1977 ; 54.5^{\circ} \mathrm{S}, 159^{\circ} \mathrm{E} ; 14 \mathrm{~m}$ depth; sponges and Codium from base of rock: 27 spec. $4-8 \mathrm{~mm}$.

P. 81123: Southern Ocean, Macquarie Island, rocks off end of Garden Bay Peninsula; sta. MA 125; 16 Dec. $1977 ; 54.5^{\circ} \mathrm{S}, 159^{\circ} \mathrm{E} ; 11 \mathrm{~m}$ depth, sponges and red algae from vertical rock face: 1 spec. juv. $2.8 \mathrm{~mm}$.

P. 81125: Southern Ocean, Macquarie Island, south-east corner of Gorilla Head Rock; sta. MA 146; 23 Dec. $1977 ; 54.4875^{\circ} \mathrm{S}, 158.96033^{\circ} \mathrm{E} ; 12 \mathrm{~m}$ depth; sponges and tunicates from exposed rock walls: 11 spec. 4-8 $\mathrm{mm}$.

P. 81126: Southern Ocean, Macquarie Island, south-east corner of Gorilla Head Rock; sta. MA 148; 23 Dec. $1977 ; 54.4875^{\circ} \mathrm{S}, 158.96033^{\circ} \mathrm{E} ; 9 \mathrm{~m}$ depth; slate-grey sponge from underside of sand and gravel bottom in Macrocystis pyrifera bedrock overhang: $11 \mathrm{spec} .4-6 \mathrm{~mm}$.

P. 81127: Southern Ocean, Macquarie Island, south-east corner of Gorilla Head Rock; sta. MA 291; 13 Jan. $1978 ; 54.6^{\circ} \mathrm{S}, 158.9^{\circ} \mathrm{E} ; 14 \mathrm{~m}$ depth; sponges on rock wall on sandy gravel bottom: 3 spec. 5-6 mm. P. 81128: Southern Ocean, Macquarie Island, Sandy Bay, off rock platform 200 m S of hut; sta. MA 241; $1 \mathrm{Jan} .1978 ; 54.6^{\circ} \mathrm{S}, 158.9^{\circ} \mathrm{E} ; 16 \mathrm{~m}$ depth; sponge, hydroid and bryozoan mat on face of large boulder on gravel bottom: 4 spec. $6 \mathrm{~mm}$.

P. 81129: Southern Ocean, Macquarie Island, Green Gorge in front of hut; sta. MA 245; 7 Jan. 1978; $54.6^{\circ} \mathrm{S}, 158.9^{\circ} \mathrm{E} ; 14 \mathrm{~m}$ depth; sponges from boulders on sand and gravel bottom in Macrocystis pyrifera bed: 3 spec. juv. $2.5-3 \mathrm{~mm}$.

P. 81130: Southern Ocean, Macquarie Island, Green Gorge, off rock platform $500 \mathrm{~m} \mathrm{~S}$ of hut; sta. MA 249; 7 Jan. $1978 ; 54.6^{\circ} \mathrm{S}, 158.9^{\circ} \mathrm{E} ; 18 \mathrm{~m}$ depth; sponges, bryozoans, tunicates and algae from boulders on rocky gravel bottom: 4 spec. $4-7 \mathrm{~mm}$.

P. 81131: Southern Ocean, Macquarie Island, Green Gorge off rock platform; sta. MA $251 ; 54.6^{\circ} \mathrm{S}$, $158.9^{\circ} \mathrm{E} ; 18 \mathrm{~m}$ depth; sponges, bryozoans, tunicates and algae from boulders on rocky gravel bottom: $>20$ spec. $5-8 \mathrm{~mm}$.

P. 81132: Southern Ocean, Macquarie Island, Green Gorge, off rock platform $500 \mathrm{~m}$ S of hut; sta. MA 287; 12 Jan. $1978 ; 54.6^{\circ} \mathrm{S}, 158.9^{\circ} \mathrm{E} ; 11 \mathrm{~m}$ depth;yellow sponge on vertical rock wall in sheltered crevice: 1 i $10 \mathrm{~mm}, 4$ spec. $6 \mathrm{~mm}$. 
P. 81133: Southern Ocean, Macquarie Island, Green Gorge, Macrocystis beds east of hut; sta. MA 149; 23 Jan. $1977 ; 54.4875^{\circ} \mathrm{S}, 158.96033^{\circ} \mathrm{E} ; 9 \mathrm{~m}$ depth; orange, white, yellow and green sponges, hydoids, bryozoans and tunicates from sheltered cave roof: $3 \mathrm{spec}$. 3-6 $\mathrm{mm}$.

P. 81134: Southern Ocean, Macquarie Island, Tottan Head, south end of Goat Bay; sta. MA 367; 30 Jan. $1978 ; 54.49167^{\circ} \mathrm{S}, 158.9625^{\circ} \mathrm{E}, 10 \mathrm{~m}$ depth, yellow sponges on vertical wall of offshore rock: 4 spec. 7-8 mm.

P. 81136: Southern Ocean, Macquarie Island, Tottan Head, south end of Goat Bay; sta. MA 370; 30 Jan. $1978 ; 54.49167^{\circ} \mathrm{S}, 158.9625^{\circ} \mathrm{E} ; 14 \mathrm{~m}$ depth; red algae, hydroids and sediment on sheltered vertical wall of offshore rock: $1 \mathrm{spec} .6 \mathrm{~mm}$.

P. 81137: Southern Ocean, Macquarie Island, Tottan Head, south end of Goat Bay; sta. MA 374; 30 Jan. $1978 ; 54.49167^{\circ} \mathrm{S}, 158.9625^{\circ} \mathrm{E} ; 14 \mathrm{~m}$ depth; encrusting sponge mat on vertical wall of offshore rock: 2 spec. $6 \mathrm{~mm}$.

P. 81138: Southern Ocean, Macquarie Island, Tottan Head, south end of Goat Bay; sta. MA 375; 30 Jan. $1978 ; 54.49167^{\circ} \mathrm{S}, 158.9625^{\circ} \mathrm{E} ; 14 \mathrm{~m}$ depth; encrusting sponge, hydroid and tunicate mat on vertical wall of offshore rock: $>20$ spec. $7-8 \mathrm{~mm}$.

P. 81140: Southern Ocean, Macquarie Island, far rocks off end of Garden Bay Peninsula; sta. MA 379; 01 Feb. $1978 ; 54.49917^{\circ} \mathrm{S}, 158.9591^{\circ} \mathrm{E} ; 11 \mathrm{~m}$ depth; sponges, hydrozoans, bryozoans from under rock overhangs and in small caves in exposed area: 2 spec. $5-6 \mathrm{~mm}, 1$ o ov. $7 \mathrm{~mm}$ (slide).

\section{NIWA, Wellington}

NIWA 7848: sta. C0730; 24 Nov. 1961; south of Macquarie Island; 5455.00’S, $158^{\circ} 47.00^{\prime} \mathrm{E} ; 110 \mathrm{~m}$ depth: 2 spec. $5 \mathrm{~mm}$.

NIWA 20875: sta. TAN 0402/231; 04 Mar. 2004; off Balleny Islands; $67.4205017^{\circ} \mathrm{S}, 163.9391632^{\circ} \mathrm{E}$ to $67.4205017^{\circ} \mathrm{S}, 163.9391632^{\circ} \mathrm{E} ; 111 \mathrm{~m}$ depth: 4 spec. $3.5-5 \mathrm{~mm}$.

? NIWA 7850: sta. B0221; 21 May 1960; New Zealand, Foveaux Strait; 46 40.00’S, 168¹6.80’E; 31 m depth: $q$ ov. $5 \mathrm{~mm}$, $q$ ov. $3 \mathrm{~mm}$.

? NIWA 7856: sta. A0013; 29 Jan. 1955; New Zealand, near Auckland; $35.9832993^{\circ} \mathrm{S}, 176.1166992^{\circ} \mathrm{E}$; 227 m depth: 1 spec. in 5 slides, 6 spec.

? NIWA 7857: no locality: 3 spec. 5-6 mm.

\section{Description}

Length

$5-8 \mathrm{~mm}$

\section{Head}

Anterior margin rounded, anterodistal margin rectangular with rounded corner. Mid-cephalic keel not prominent. Rostrum small.

Eyes large, round.

Antennae short and robust, A $1<1 / 3$ of body length, flagellum 10-12-articulate, peduncle art. 1 width twice the one of article 2, disto-inferiorly without acute tooth, length art. 1 subequal to art. 2, art. 3 about 1/3-1/2 of art. 2, acc. flagellum not seen. Peduncle art. 3 + flagellum shorter than peduncle arts $1+2$.

A 2 subequal in length to antenna 1, peduncle art. $4>$ art. 5, flagellum 7-10 arts.

Mouthparts: Mandibles lacking molars, incisor and lacinia mobilis dentate; palp 3-articulate, art. 2 with 12 long lateral setae, art. 3 with 2 distal setae, equal to half length of art. 2. Mx 1 palp sometimes with indistinct suture, which has been recorded for the first time by White \& Thomas (2009). Mx 2 with riding position of the plates, $\mathrm{OP}$ narrow. 


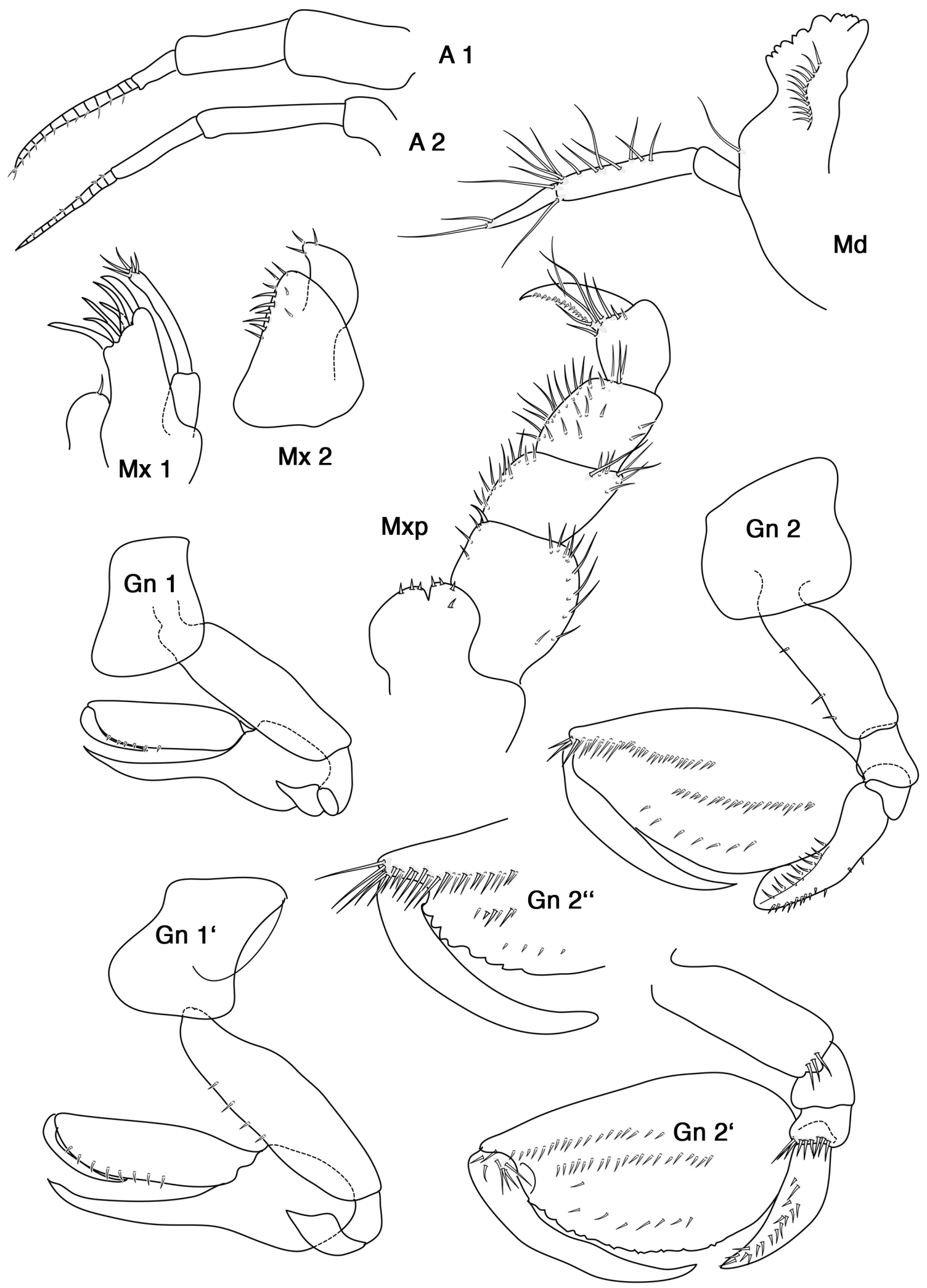

Fig. 11. Leucothoe macquariae sp. nov., NIWA 7856 sta. A0013 1 spec. in 5 slides. A 1, $2=$ antenna 1 , $2 ; \mathrm{Md}=$ mandible; $\mathrm{Mx} 1,2=$ maxilla 1, 2; $\mathrm{Mxp}=$ maxilliped; $\mathrm{Gn} 1=$ gnathopod $1 ; \mathrm{Gn} 1{ }^{\prime}=$ gnathopod of other specimen from same sample; Gn 2 = gnathopod 2; Gn 2', Gn 2" = second gnathopods of other specimens from same sample. 


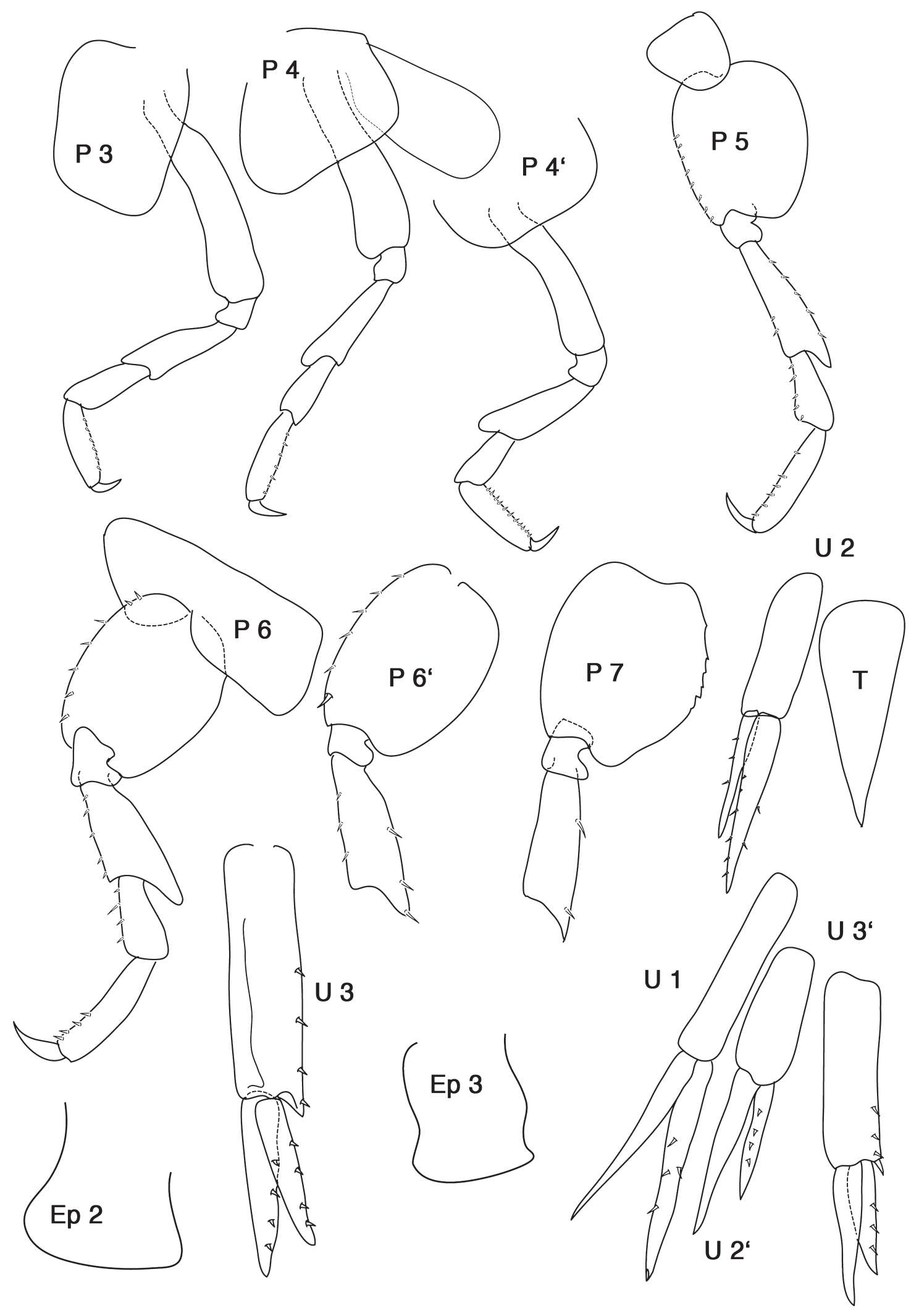

Fig. 12. Leucothoe macquariae sp. nov., NIWA 7856 sta. A0013 1 spec. in 5 slides. P 3-7 = peraeopod 3-7; P 4', P 6' = peraeopods of other specimens; Ep 3 = third epimeral plate; U 1-3 = uropod 1-3; U 2', $\mathrm{U} 3^{\prime}=$ uropods of other specimens; $\mathrm{T}=$ telson. 
Mxp robust, IP small, nearly fully fused medially, OP absent; palp articles unusually wide, subquadrate.

\section{Peraeon}

Cx 1 smooth, length > width; anterior margin smooth, facial setae absent, inferior margin smooth.

Gn 1 basis scarcely inflated, anterior margin with some short setae; ischium smooth; carpus basis more than half as long as propodus, distal part linear, narrow, about $6 \times$ longer than wide; propodus straight, about $3-3.5 \mathrm{x}$ as long as wide, palm with 8 short setae; dactylus smooth, reaching nearly $1 / 2$ propodus length.

Cx 2 subquadrangular, about as long as wide, much wider than $\mathrm{Cx} 3$, distally smooth; anterior margin rounded, anterodistal corner rectangularly rounded, inferior margin straight, posterior margin excavated, facial setae absent.

Gn 2 basis not inflated, on anterior margins 3 short setae; carpus nearly reaching one third of propodus length, curved, distally rounded, densely setose; propodus anterodistally without prolongation, with a bundle of setae, posterior margin in male with many low humps, in female smooth, palm convex, proximally near dactylus-end no corner; facial setae medially and submedially present; dactylus curved, both margins smooth, bare, reaching somewhat more than half of propodus length.

Cx 3 length $>$ width, anterior and posterior margin straight, subrectangular, smooth, facial setae absent.

Cx 4 length subequal to width, smooth, bare, anterior margin straight, distal margin oblique, posterior margin clearly shorter than anterior one, not excavate, facial setae absent.

P 3, 4 basis very narrow, a bit wider than merus; dactylus reaching nearly half length of propodus, posterior margins naked.

Cx 5-7 facial setae absent.

P 5-7 similar, bases length:width ratio about 1.3 (P 5) to 1.2 (P 7), anterior margins with small weak spines, posterior margins in $\mathrm{P} 5,6$ smooth, in $\mathrm{P} 7$ weakly serrate. Merus to propodus anterior margin with small spines, in merus also posterior margin; merus with posterodistal corner lengthened.

\section{Pleon}

Ep 1-3 bare. Ep 2 posteroventral corner scarcely lengthened and rounded. Ep 3 posteroventral corner blunt, with small rounded and somewhat upturned corner.

Uropods: U 2 the shortest, with unequal rami (ratio about 1.4), the shorter one shorter than peduncle. $\mathrm{U} 3$ peduncle more robust than in the other species, margine spinose; rami unequal, ratio 1.2 to 1.25.

Telson ratio $1: \mathrm{w}=2.7$, margins smooth, tip acute.

\section{Distribution}

sub-Antarctic (Macquarie Island, $54^{\circ} \mathrm{S}$ ) and Antarctic waters (Balleny Islands, 67 ${ }^{\circ} \mathrm{S}$ ); records from temperate waters (New Zealand: $35^{\circ} \mathrm{S}, 46^{\circ} \mathrm{S}$ ) to be confirmed.

\section{Habitat}

From Codium sp., red algae, Macrocystis pyrifera holdfasts, sponges, bryozoans, colonial tunicates and sand or gravel bottom. 


\section{Depth range}

$5-227 \mathrm{~m}$.

\section{Remarks}

This species has some similarity to L. antarctica, but $\mathrm{P} 7$ basis is less wide and has always a lengthened posterodistal corner (nearly semi-circularly rounded, corner not or scarcely lengthened in L. antarctica); Gn 1 propodus is much more robust here and $\mathrm{U} 3 \mathrm{rami}$ are unequal (vs. $\mathrm{U} 3$ slender with equal rami in L. antarctica); Ep 3 has a somewhat upturned rounded posterodistal corner (vs. rectangular corner in L. antarctica).

\section{Leucothoe merletta sp. nov. urn:1sid:zoobank.org:act:6C2BCD72-777F-4825-B595-A23EBFE445C9}

Figs 5, 13-14

\section{Diagnosis}

Eyes round, yellowish. Mandibular palp art. 3 nearly as long as art. 2. Cx 2 smooth, in shape of a parallelogram, anterodistal corner acutely lengthened. Cx 4 also with anteridistal corner acutely lengthened, but posterior margin much shorter than anterior one. Gn 1 propodus l:w $=4$, dactylus reaching nearly $1 / 2$ of propodus length. P 5-7 basis oval, with regularly rounded hind margin, ratio 1:w about 1.5; posterior margin in P 7 smooth. Ep 2 distoposterior corner slightly upturned, Ep 3 posterodistally with rectangular corner. $\mathrm{T}$ 1:w not known.

\section{Etymology}

In Italian "merletto" is the bobbin lace; as the very acutely elongated Cx 2 and $C x 4$ can remind on lacecollars, this epitheton (Latinized flexible adjective) was coined.

\section{Type material}

Holotype ㅇ 2.5 mm, Belgian-Dutch Antarctic Expeditions (RBINS, I.G. 23694 / INV. 103463); EABN 1966-67: sta. 238; 3 Feb. 1967; Breid Bay, Baie Léopold; 70¹9'S, 24¹4'E; 200 m; bottom trawl; coll. M. Steyaert \& M. Meisch.

\section{Description}

\section{Length}

$2.5 \mathrm{~mm}$.

\section{Head}

Anterior margin rounded, anterodistal margin rectangular with rounded corner. Mid-cephalic keel not prominent. Rostrum small.

Eyes round, yellow.

Antennae short and robust, A 1 flagellum 5-articulate, peduncle art. 1 subequal in length but twice the width of article 2, disto-inferiorly without acute tooth, art. 3 nearly $1 / 2$ of art. 2 , acc. flagellum not seen. Peduncle art. 3 + flagellum about as long as peduncle art. 2.

A 2 subequal in length with antenna 1, peduncle art. $4>$ art. 5 , flagellum 4 arts.

Mouthparts: Mandibles lacking molars, incisor and lacinia mobilis dentate; palp 3-articulate, art. 2 with 4 long lateral and one distal setae, art. 3 with 2 distal setae, subequal to art. 2. 


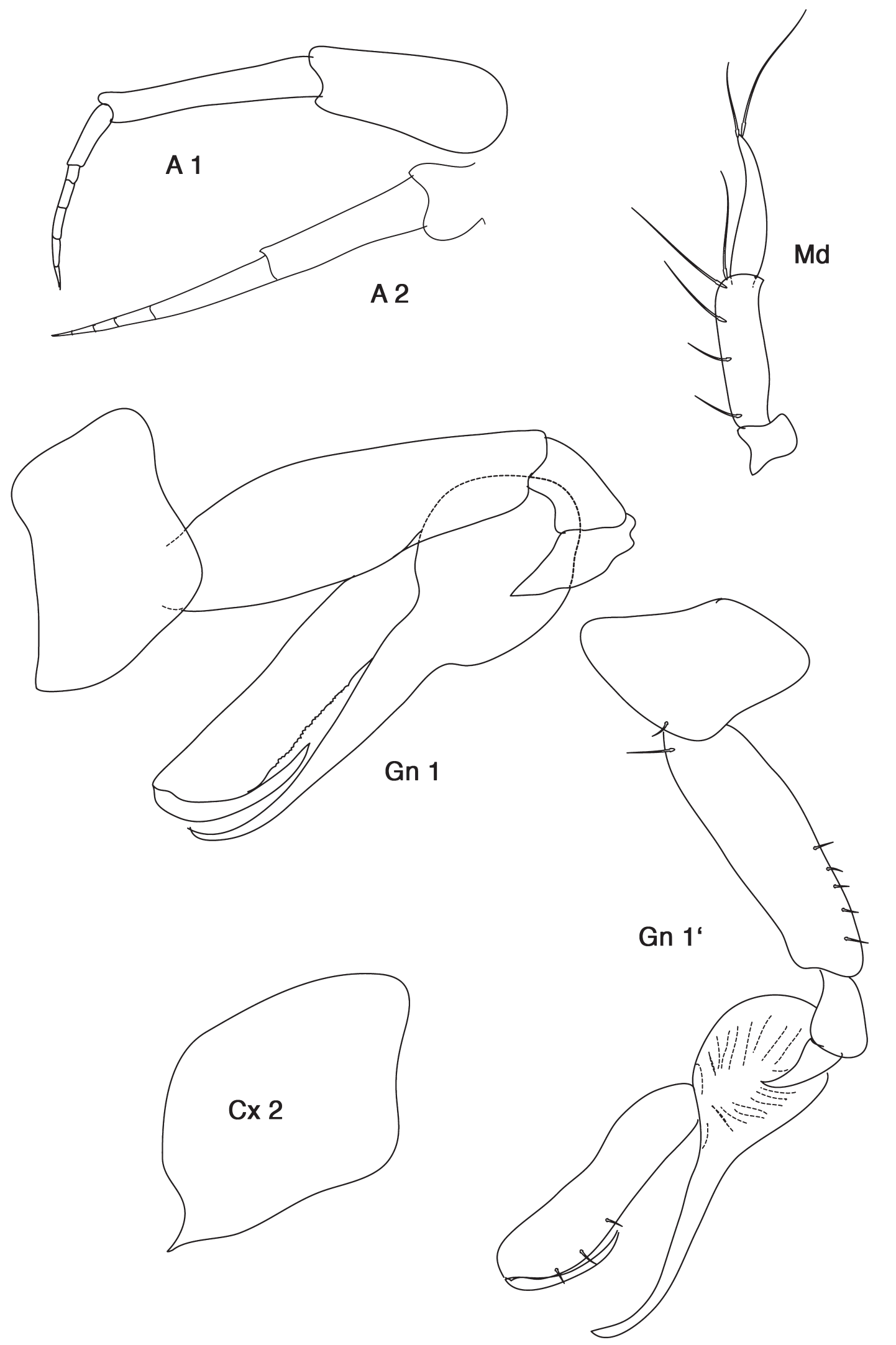

Fig. 13. Leucothoe merletta sp. nov., holotype $q 2.5 \mathrm{~mm}: \mathrm{A} 1,2=$ antenna 1, 2; Md = mandible; Gn $1=$ gnathopod 1; Gn 1'= gnathood 1 reduced and from other side; $\mathrm{Cx} 2=$ coxa 2 . 

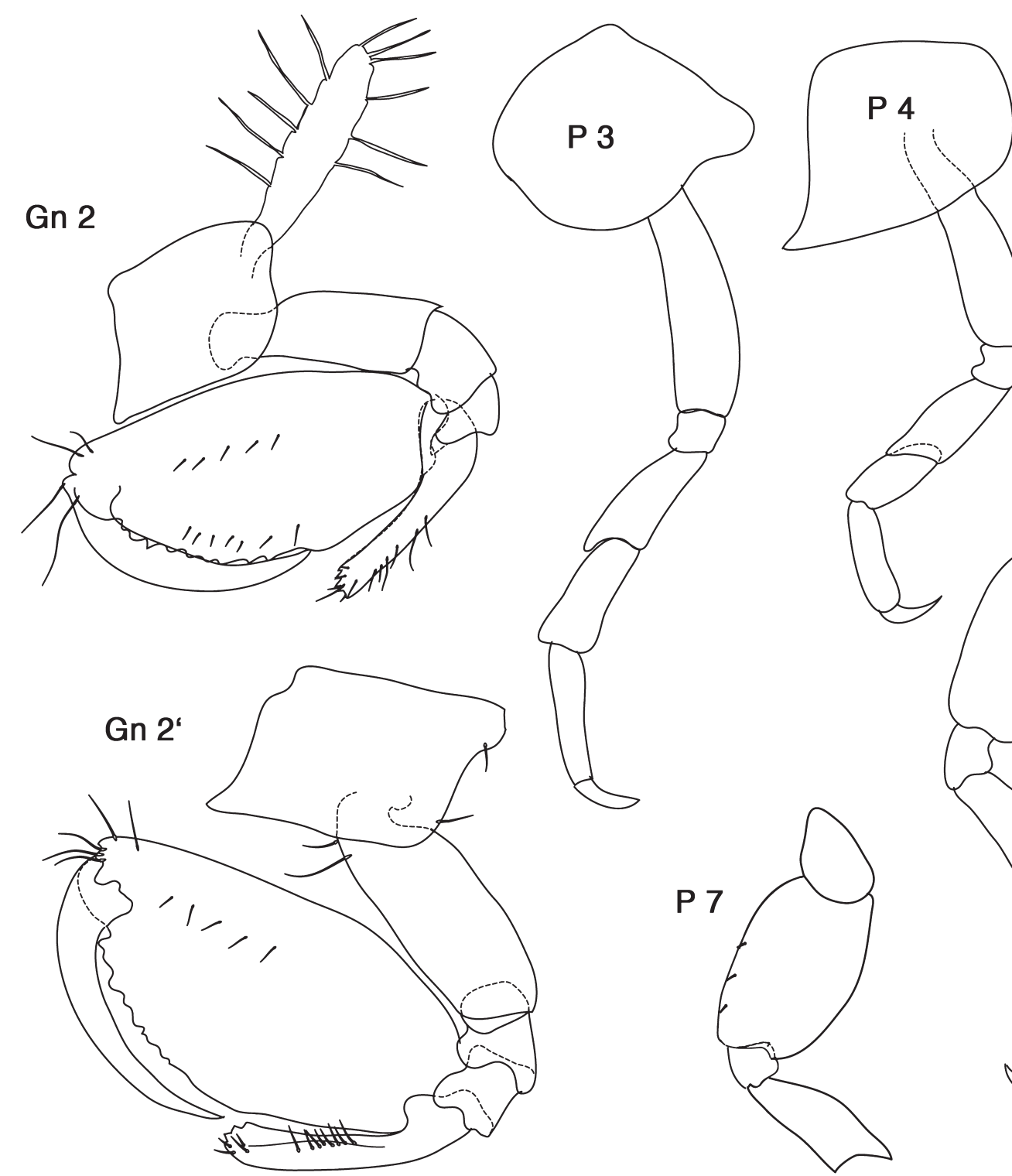


\section{Peraeon}

Cx 1 smooth, length > width; anterior margin smooth, anterodistal corner somewhat lengthened, facial setae absent, inferior margin smooth.

Gn 1 basis somewhat inflated, smooth; ischium smooth; carpus basis more than half as long as propodus, distal part linear, narrow, about 7-9 x longer than wide (width very different); propodus straight, about $5 \mathrm{x}$ as long as wide, palm smooth; dactylus smooth, reaching more than $1 / 3$ propodus length.

Cx 2 about as wide as long, in the shape of a parallelogram, width similar to Cx 3, distally smooth; anterior margin scarcely excavate, anterodistal corner acutely lengthened, inferior and posterior margin straight, facial setae absent.

Gn 2 basis not inflated, on anterior margin some setae; carpus nearly reaching half propodus length, curved, distally rounded, with small incision, setose; propodus anterodistally without prolongation, with some setae, posterior margin with many low humps, palm convex, proximally near dactylus-end with weak blunt corner; facial setae medially and submedially present, but not abundant; dactylus curved, both margins smooth, bare, reaching somewhat more than half of propodus length.

Cx 3 length subequal to width, rounded, anterior and posterior margin straight, quadrangular, smooth, facial setae absent.

Cx 4 length shorter then width, smooth, bare, anterior margin distally excavate, anterodistal corner acutely pointed and lengthened, posterior margin clearly shorter than anterior one, rounded, facial setae absent.

P 3, 4 basis slender, width subequal to merus; dactylus reaching nearly half length of propodus, posterior margins smooth.

Cx 5-7 facial setae absent.

P 5-7 similar, bases 1:w ratio about 1.5, margins smooth. Merus with posterodistal corner scarcely lengthened and not widened.

\section{Pleon}

Ep 1-3 bare. Ep 2 posterodistal corner somewhat upturned, rounded; Ep 3 posteroventral corner blunt, rectangular.

Uropods: U 2 with unequal rami, the shorter one shorter than peduncle. U 3 unknown.

Telson ratio l:w unknown.

\section{Remarks}

Until now we know only one representative of this new species, but the peculiar shape of Cx 2 and Cx 4 makes it easy to recognize it within the Antarctic and sub-Antarctic species. Within the hitherto known Leucothoe species L. lilljeborgi (Boeck, 1861) as well as L. ayrtonia Bellan-Santini, 1997 have a similar Cx 4 with a pointed anterodistal corner but rounded Cx 2, while L. angusticoxa (Ledoyer, 1972), described as "Leucothopsis n. gen.", has Cx 2 pointed and $\mathrm{Cx} 4$ rounded.

\section{Distribution}

East Antarctic, off Queen Maud Land, Breidbay $\left(70^{\circ} \mathrm{S}, 24^{\circ} \mathrm{E}\right)$.

\section{Depth range}

$200 \mathrm{~m}$. 
Leucothoe orkneyi Holman \& Watling, 1983

Figs 15-18

Leucothoe orkneyi Holman \& Watling, 1983: 231-233, figs 12-14.

\section{Diagnosis}

Eyes medium, round. Mandibular palp long and narrow, art. 3 1/2-1/3 length of art. 2 (in original description verbally reported 1/3, but illustration shows 1/2). Cx 1 1:w subequal. Cx 3 subtrapezoidal, inferior margin serrate. Gn 1 carpus distal part about 8-9 x longer than wide, propodus ratio 1:w $=6$, dactylus reaching about $1 / 5$ of propodus length. P 5-7 basis oval and not much broadened, with regularly rounded hind margin, ratio 1:w 1.8 to 1.5 ; posterior margin strongly serrate (not mentioned in original description). Ep 2 posterodistally with upturned acute tip, Ep 3 with posterodistally rounded. T 1:w $=<3$.

\section{Type locality}

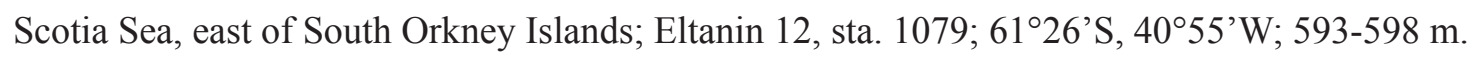

\section{Material examined}

Australian Museum, Sydney

P. 25494: Ross Ice-Shelf, McMurdo Sound, White Island, tide crack; 25 Jan. 1977; [approx. $78^{\circ} 08^{\prime}$ S, 167²4'E]; $67 \mathrm{~m}$ depth; on rocky bottom encrusted with bryozoans and hydroids: $1 \mathrm{spec} .4 \mathrm{~mm}$.

\section{Belgian-Dutch Antarctic Expeditions}

(RBINS, Brussels, EABN 1966-67, coll. M. Steyaert \& M. Meisch, RBINS I.G. 23694)

EABN 1966-67: sta. 232; 25 Jan. 1967; Breid Bay, Baie Léopold III; 70¹7’00”S, 24¹5’E; 300 m, bottom trawl: 1 spec. $6 \mathrm{~mm}$.

\section{British Antarctic Survey, Cambridge}

James Clark Ross 179: sta. BIO4 - EBS-3D-E; Amundsen Sea; $74.390880^{\circ} \mathrm{S}, 104.767260^{\circ} \mathrm{W} ; 506$ m; Epibenthic Sled-Epinet: $1 \mathrm{spec} .4 .5 \mathrm{~mm}$, slide.

\section{NIWA, Wellington}

NIWA 20875: Tangaroa sta. TAN0402/231; 4 Mar. 2004; off Balleny Islands; $67.4205017^{\circ} \mathrm{S}$, $163.9391632^{\circ} \mathrm{E}$ to $67.4205017^{\circ} \mathrm{S}, 163.9391632^{\circ} \mathrm{E}$; $111 \mathrm{~m}: 4$ spec. $3.5-5 \mathrm{~mm}$.

\section{Polarstern cruises}

(RBINS, Brussels, ANT XIII/3 (EASIZ I), coll. C. De Broyer \& G. Chapelle, RBINS I.G. 28252; ANT XV/3 (EASIZ II), coll. C. De Broyer \& Y. Scailteur, RBINS I.G. 28252; ANT XXII/3 (ANDEEP III), coll. C. De Broyer \& B. Danis, RBINS I.G. 32565.)

ANT XIII/3 (EASIZ I): sta. PS39/005; 6 Feb. 1996; eastern Weddell Sea; SW of Kapp Norvegia;

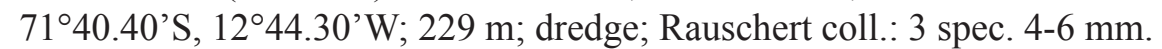

ANT XIII/3 (EASIZ I): sta. PS39/006; 7 Feb. 1996; eastern Weddell Sea; 71³0.80’S, 13³1.44’W; $300 \mathrm{~m}$; dredge; Rauschert coll.: 2 spec. 3-5 mm.

ANT XIII/3 (EASIZ I): sta. PS39/007; 8 Feb. 1996; eastern Weddell Sea; 71²28.60'S, $13^{\circ} 45.10^{\prime} \mathrm{W}$; $279 \mathrm{~m}$; dredge; Rauschert coll.: $1 \mathrm{spec} .4 \mathrm{~mm}$.

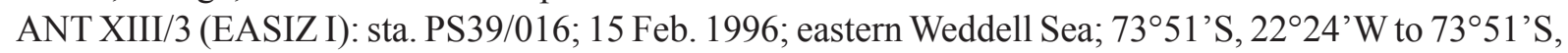
22॰25'W; 246-252 m; dredge; Rauschert coll.: 1 spec. 4 mm.

ANT XIII/3 (EASIZ I): sta. PS39/017; 16 Feb. 1996; eastern Weddell Sea; 73¹9’S, 211’’W, 447 m; dredge; Rauschert coll.: 4 spec. 2-5.2 mm. 
ANT XIII/3 (EASIZ I): sta. PS39/024 MG26; 21 Feb. 1996; eastern Weddell Sea; 718.10’S, 11³1.90’W, $118 \mathrm{~m}$; Multibox Corer: $1 \mathrm{spec} .5 \mathrm{~mm}$.

ANT XIII/3 (EASIZ I): sta. PS39/002 MG27; 22 Feb. 1996; eastern Weddell Sea; 71¹9’04”S, $12^{\circ} 24^{\prime} 48^{\prime \prime}$; $182 \mathrm{~m}$; Multibox Corer: $3 \mathrm{spec} .3 \mathrm{~mm}$.

ANT XIII/3 (EASIZ I): sta. PS39/002 MG28; 22 Feb. 1996; eastern Weddell Sea; 71¹9’06”S, $12^{\circ} 22^{\prime} 48^{\prime \prime} \mathrm{W}$; $159 \mathrm{~m}$; Multibox Corer: 2 spec. 4, $5 \mathrm{~mm}$.

ANT XIII/3 (EASIZ I): sta. PS39/002 MG29; 22 Feb. 1996; eastern Weddell Sea; 71¹8’36”S, $12^{\circ} 25^{\prime} 24^{\prime \prime} \mathrm{W}$; $181 \mathrm{~m}$; Multibox Corer: $2 \mathrm{spec} .2,5 \mathrm{~mm}$ and 3,5 $\mathrm{mm}$.

ANT XIII/3 (EASIZ I): sta. PS39/002 MG 30; 22 Feb. 1996; eastern Weddell Sea; 71¹9’12’'S, 12²7’W; $253 \mathrm{~m}$; Multibox Corer: 1 spec. sex? $5 \mathrm{~mm}$ (with red eyes).

ANT XIII/3 (EASIZ I): sta. PS39/025 MG31; 23 Feb. 1996; eastern Weddell Sea; 71²3'06”'S, 14¹9'48”'W; $628 \mathrm{~m}$; Multibox Corer: $1 \mathrm{spec} .5 \mathrm{~mm}$.

ANT XIII/3 (EASIZ I): sta. PS39/026; 24 Feb. 1996; eastern Weddell Sea; 71²9'S, $14^{\circ} 19^{\prime} \mathrm{W}$ to $71^{\circ} 29^{\prime} \mathrm{S}$, 14¹9’W; 210-214 m; dredge 21; Rauschert coll.: 6 spec. 3-6.5 mm.

ANT XIII/3 (EASIZ I): sta. PS39/032; 04 Mar. 1996; eastern Weddell Sea; 70²8’S, 8¹5'W to $70^{\circ} 28^{\prime}$ 'S $8^{\circ} 15^{\prime} \mathrm{W}$; 283-286 m: 9 spec. 4-6 mm.

ANT XV/3 (EASIZ II): sta. PS48/039; 29 Jan. 1998; eastern Weddell Sea; 7052.8’S, 10³1.4'W; $237 \mathrm{~m}$; Agassiz Trawl: §o $6 \mathrm{~mm}$.

ANT XXII/3 (ANDEEP III): sta. PS67/133-2-EBS; 16 Mar. 2005; western Weddell Sea, Powell Basin; 62 ${ }^{\circ} 46.49^{\prime} \mathrm{S}, 53^{\circ} 3.50^{\prime} \mathrm{W}$; $1584 \mathrm{~m}$; EBS-Epinet: 2 juv. $4 \mathrm{~mm}$; 20 spec. 4-5 mm; EBS-Supranet: 1 spec. $5 \mathrm{~mm}$.

\section{Polish Antarctic Expeditions (LPBO-UL, Lódź)}

3rd Polish Biol. Ant. Exp. 1974: sta. PABE III-46; 4 Nov. 1974; Enderby Land, Alasheyev Bight,

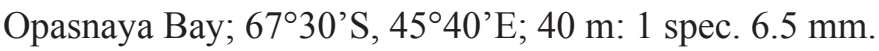

9th Polish Ant. Exp.1985: sta. OC 419; 18 Jan. 1985; King George Island, Admiralty Bay, section 1; 62 $09,0194^{\prime}$ 'S, 58 26,510’W; 380 m; Van Veen Grab: 1 ad. 5 mm.

9th Polish Ant. Exp. 1985: sta. OC 481; 23 Jul. 1985; King George Island, Admiralty Bay, Section I, 6209.154’'S, 58²6.929’W, 205 m, Van Veen Grab: 1 ad. 5 mm.

9th Polish Ant. Exp. 1985: sta. OC 486; 10 Aug. 1985; King George Island, Admiralty Bay, section I; 62 $09,067^{\prime} \mathrm{S}, 58^{\circ} 26,797^{\prime} \mathrm{W} ; 270$ m; Van Veen Grab: 1 spec.

9th Polish Ant. Exp. 1985: sta. OC 517; 30 Oct. 1985; King George Island, Admiralty Bay, Section I; 62009.149’S, 58²6.927’W; 212 m, Van Veen Grab: 1 spec. 4 mm.

9th Polish Ant. Exp 1985: sta. OC 520; 3 Nov. 1985; King George Island, Admiralty Bay, section I; $62^{\circ} 09^{\prime} \mathrm{S}, 58^{\circ} 25^{\prime} \mathrm{W}$; $335 \mathrm{~m}$; Van Veen Grab: 2 spec.

\section{Victoria Museum, Melbourne}

J 38265: Aurora Australis sta. AA93 127; MacRobertson Shelf, edge of Nielsen Basin;

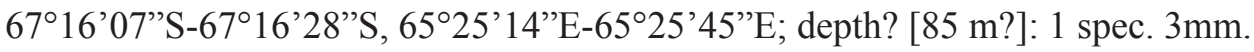

J 38266: Aurora Australis sta. AA93 131; off Mac Robertson Land, northern end of Fram Bank;

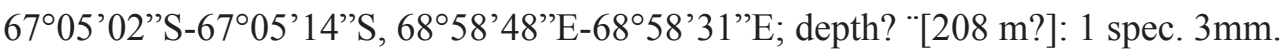

J 38268: Aurora Australis sta. AA93 158; Eastern Prydz Bay, off the Larsemann Hills;

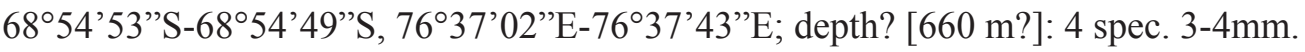

\section{Redescription}

\section{Length}

4-9 mm. 


\section{Head}

Anterior margin rounded, anterodistal margin rectangular with rounded corner. Mid-cephalic keel with acute projection, extending past epistome. Rostrum small.

Eyes small, round, red colour remaining some time in alcohol (Holman \& Watling 1983: 231).

Antenna 1 one third of body length, flagellum 7 -articulate, peduncle art. 1 width proximally less than twice article 2, disto-inferiorly with acute tooth, length art. 1 subequal to art. 2, art. 3 about 1/3 of art. 2, acc. flagellum not seen. Peduncle art. 3 + flagellum subequal to peduncle art. 2.

Antenna 2 subequal in length with antenna 1, peduncle art. $4>$ art. 5, flagellum 6 arts.

Mouthparts: Mandibles lacking molars, incisor and lacinia mobilis dentate; palp 3-articulate, art. 2 with 6 long lateral and 4-5 distal setae, art. 3 with 2 distal setae, 1/3 length of art. 2. Maxilliped IP small, ventrally fused, OP reaching about $1 / 5$ of inner margin of palp art. 1; palp articles similar in length, all clearly longer than wide.

\section{Peraeon}

Cx 1 smooth, length and width subequal; anterior margin smooth, facial setae absent.

Gn 1 basis somewhat widened, lacking setae; ischium smooth; carpus basis about half as long as propodus, distal part linear and extremely narrow (width not much differing, about 9 long); propodus straight, $7-8 \mathrm{x}$ as long as wide, palm minutely dentate with 12 short and up to 8 longer setae; dactylus smooth, reaching about $1 / 5$ propodus length.

Cx 2 subquadrangular, about as long as wide, much wider than $\mathrm{Cx} 3$, distally smooth; anterior margin straight, anterodistal corner rectangular, inferior and posterior margin straight, facial setae absent.

Gn 2 basis not inflated, on both margins up to 14 short setae and on anterior margin one longer one; carpus reaching about $1 / 3$ propodus length, curved, distally truncate, with small serration, densely setose; propodus anterodistally with short acute prolongation and bundle of setae, posterior margin with many low humps, palm convex, proximally near dactylus-end widening with a characteristic blunt corner; one row of facial setae below the middle line; dactylus curved, both margins smooth, bare, reaching more than half of propodus length.

Cx 3 length $>$ width, anterior and posterior margin straight, distally rounded and irregularly serrate, facial setae absent.

Cx 4 wider than long, smooth, bare, anterior margin scarcely convex, distal margin rounded, posterior margin shorter than anterior one, not excavate, facial setae absent.

P 3, 4 basis slender, a bit wider than merus; merus anterodistally lengthened; dactylus reaching more than half length of propodus.

Cx 5-7 facial setae absent.

P 5-7 similar, bases 1:w ratio about 1.9 to 1.5 , anterior margins with slight serrations and small weak spines, posterior margins strongly serrate (not mentioned in original description). 


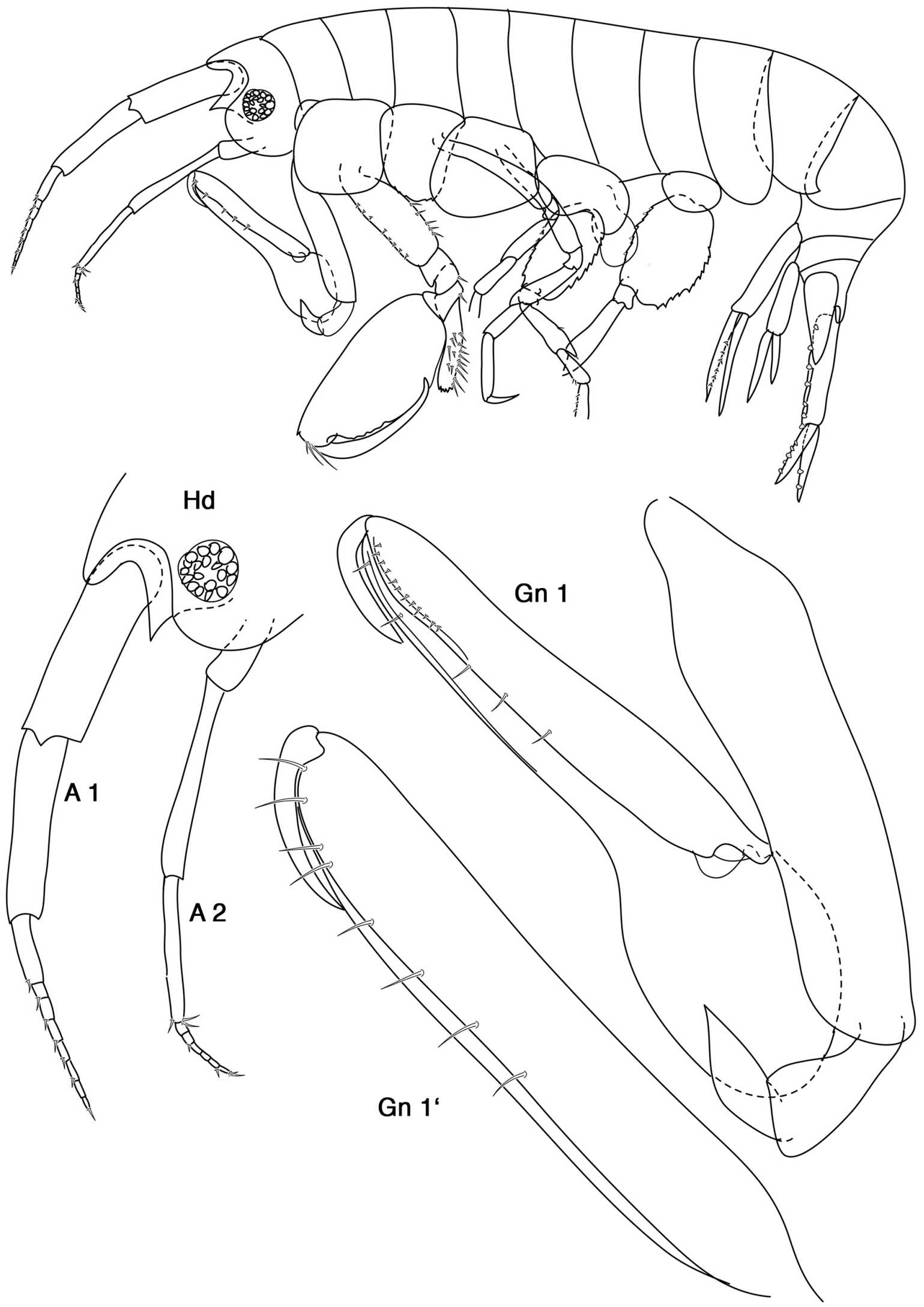

Fig. 15. Leucothoe orkneyi Holman \& Watling, 1983: Hd = head; A 1, $2=$ antenna 1, 2; Gn $1=$ first gnathopod; Gn 1' = dactylus and propodus of first gnathopod enlarged. 


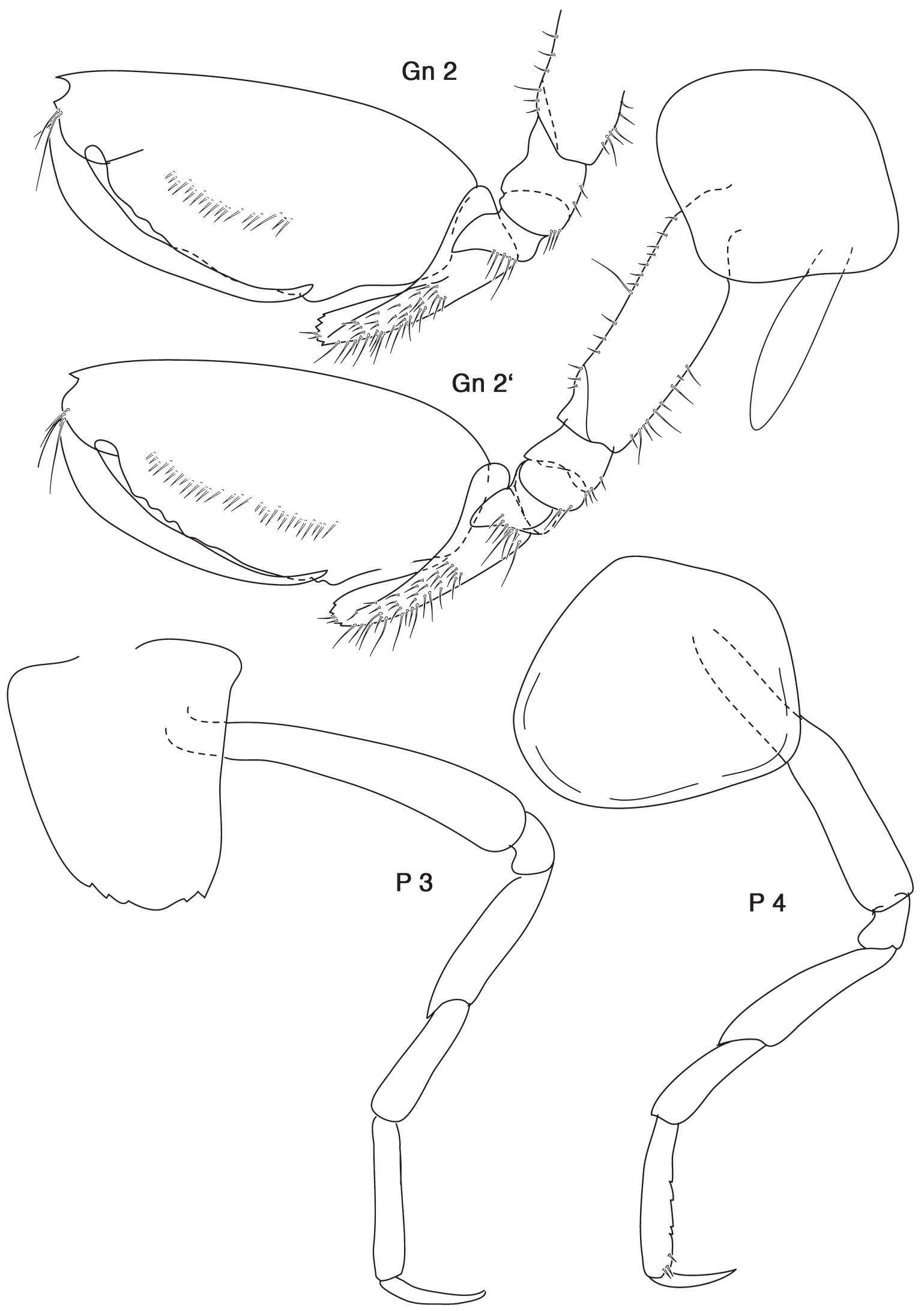

Fig. 16. Leucothoe orkneyi Holman \& Watling, 1983: Gn 2, Gn 2' = second gnathopod from both sides; P 3, $4=$ peraeopod 3, 4 . 


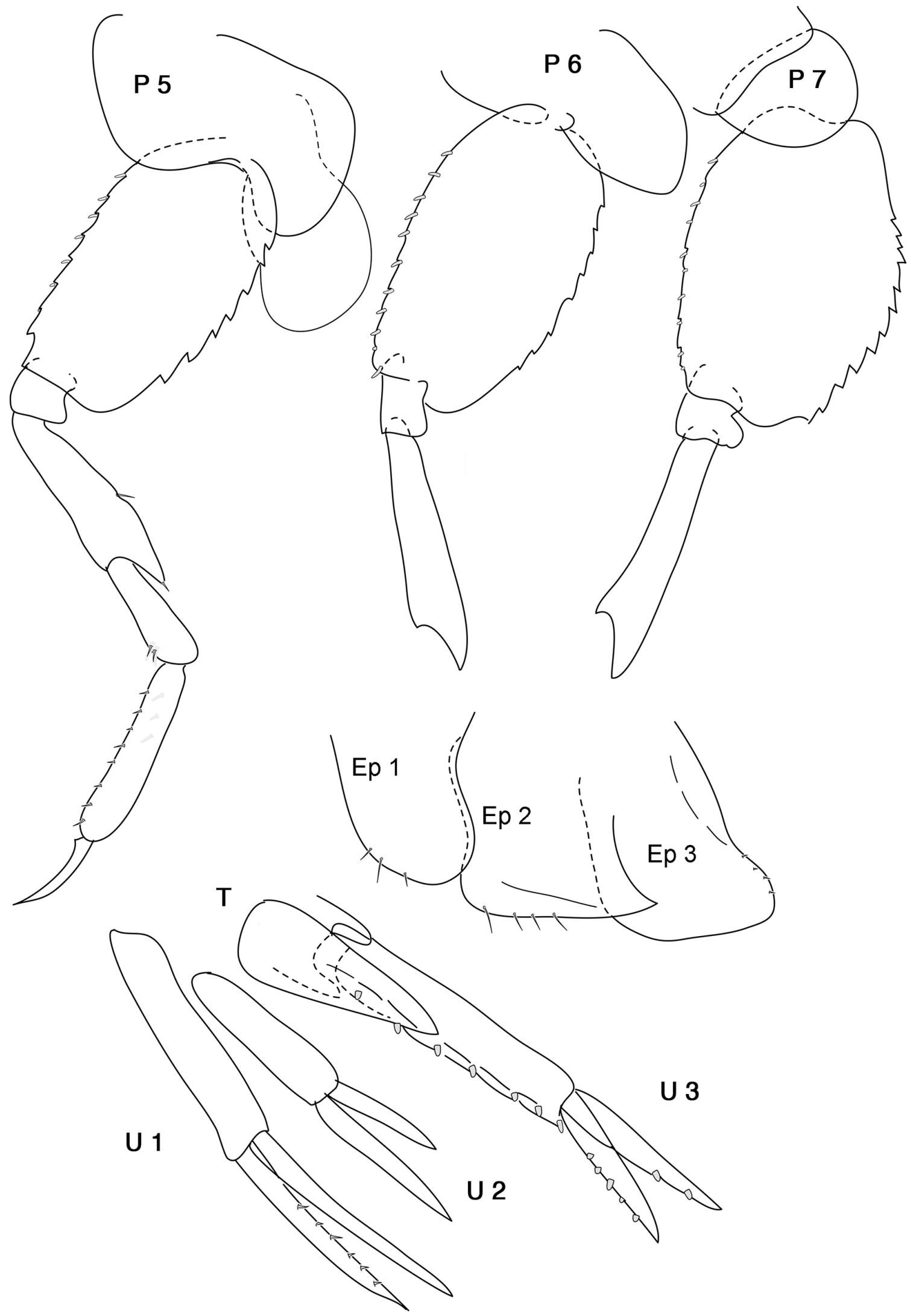

Fig. 17. Leucothoe orkneyi Holman \& Watling, 1983: P 5-7 = peraeopod 5-7; Ep 1-3 = epimeral plates 1-3; U 1-3; uropod 1-3; T = telson. 


\section{Pleon}

Ep 1-2 with spines on distal margin, Ep 3 distally bare, but some short setae on posterior margin. Ep 1 posteroventral corner rounded, Ep 2 posteroventral corner acutely produced, Ep 3 posteroventral corner blunt and rectangular.

Uropods: $\mathrm{U} 2$ the shortest, with unequal rami (ratio 1.5), the shorter one shorter than peduncle.

Telson ratio 1:w $>3$, tip tridentate because of two indentations near distal end, with a short seta inserted in each one.

\section{Distribution}

Circum-Antarctic $\left(61^{\circ}-73^{\circ} \mathrm{S}, 8^{\circ}-58^{\circ} \mathrm{W}\right.$ and $24^{\circ}-167^{\circ} \mathrm{E}$; type material $\left.60^{\circ} 35^{\circ} \mathrm{S}, 45^{\circ} 30^{\prime} \mathrm{W}\right)$.

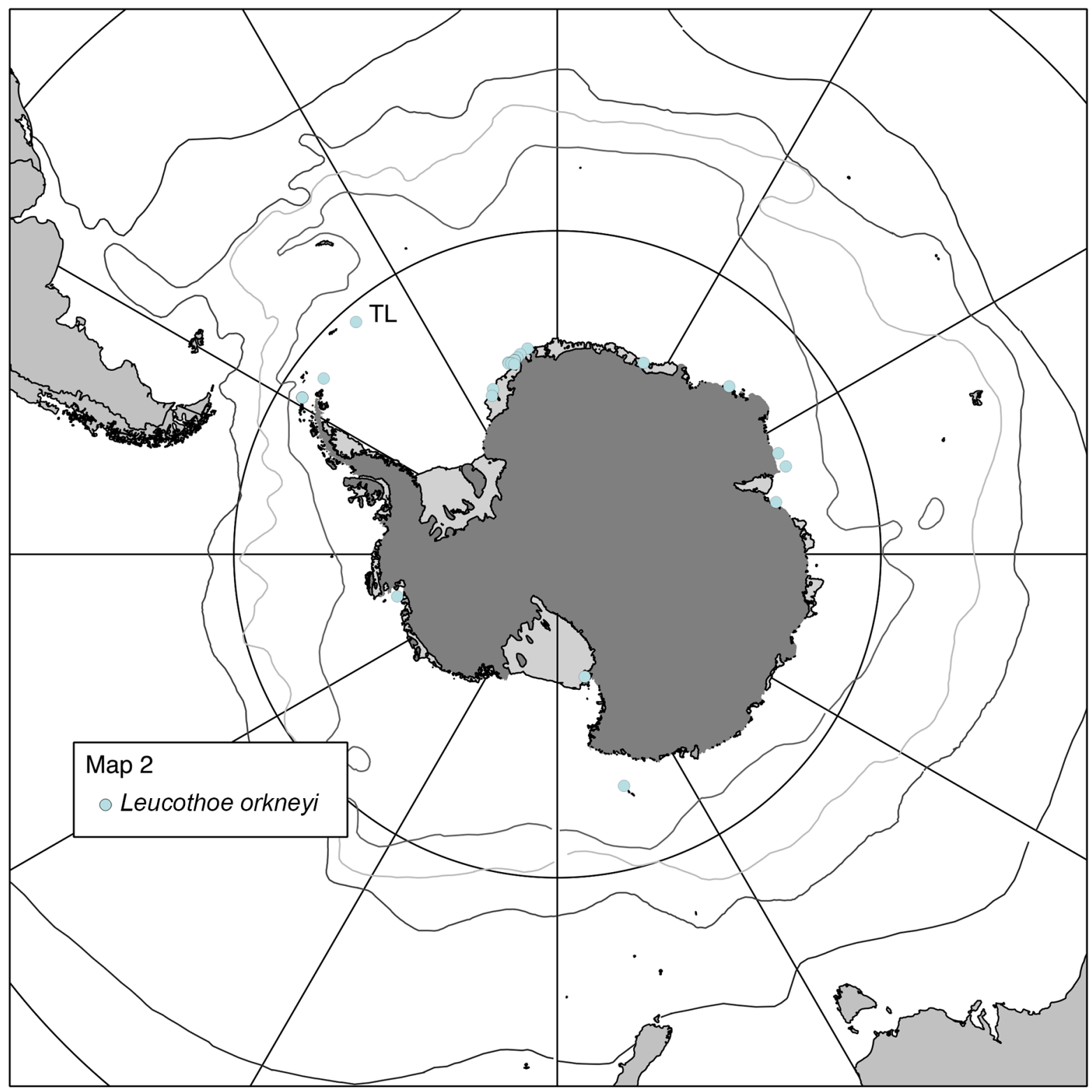

Fig. 18. Distribution of Leucothoe orkneyi. Hydrographic fronts as in Fig. 5. TL = type locality. 


\section{Depth range}

$11-1584 \mathrm{~m}$.

\section{Remarks}

The material examined here matches the description and figures of Holman \& Watling quite well, but our specimens are always considerably smaller, found at shallower depth and their peraeopod bases are posteriorly serrate. Moreover the original description tells about specimens of 4.5-6.5 mm from $61^{\circ} 27^{\prime} \mathrm{S}, 41^{\circ} 55^{\prime} \mathrm{W}$, while others from a similar area were between 6.5 and $9 \mathrm{~mm}$, both localities from about $600 \mathrm{~m}$ depth. On p. 230-231 (loc. cit.) the authors wrote: "[...] of P 7, the basis of which appeared broadly rounded. Some slight variability in the degree of expansion of this article was seen [...], so its diagnostic value is questionable."

Thus it could very well be that this material consists of a group of closely related and morphologically extremely similar species.

Holman \& Watling (loc. cit.) compare their new species to L. tridens Stebbing, 1888, L. miersi Stebbing, 1888, L. trailli Thomas, 1882, L. commensalis Haswell, 1880, L. diemensis Haswell, 1880, L. assimilis J.L. Barnard, 1974 and L. hyhelia J.L. Barnard, 1970, which all differ from this new species in the shape of the first gnathopod. L. panpulco J.L. Barnard, 1961 and L. uschakovi Gurjanova, 1951 (up to $34 \mathrm{~mm}$ maximal length, $3000 \mathrm{~m}$, see redescription in Krapp-Schickel \& Vader 2012) have different bases on P 5-7, L. ctenochir K.H. Barnard, 1916 has a very characteristic palm on Gn 2.

Leucothoe weddellensis sp. nov. urn:1sid:zoobank.org:act:2069CF2D-D7B6-4A96-874A-46818C6A3344

Figs 19-27

sub L. spinicarpa variant 1 - Holman \& Watling 1983: 227-230 fig. 10 (but see also discussion about $L$. spinicarpa variant 1 and 2).

\section{Etymology}

The latinized adjective refers to the fact that much of the material comes from the Weddell Sea.

\section{Type material}

Holotype + ov. $20 \mathrm{~mm}$ (in alcohol) (RBINS, Brussels, I.G. 31073/ INV. 103464); Polarstern ANT XIX/3 (ANDEEP I): sta. PS61/067 GSN; 4 Feb. 02; Scotia Sea, north to Elephant Island; 6055'53”S, $55^{\circ} 27^{\prime} 38^{\prime \prime}$ W to $60^{\circ} 55^{\prime} 09^{\prime}$ 'S, $55^{\circ} 24^{\prime} 50^{\prime \prime} \mathrm{W}$; $115-182 \mathrm{~m}$; bottom trawl; coll. C. De Broyer, P. Dauby \& F. Nyssen.

\section{Preliminary remarks}

Before starting to cite the localities, we have to explain the division in two parts:

Quite like Holman \& Watling (loc. cit.) we hesitated between attributing the entire material to one species, or dividing the material into two new species. Like the cited authors we first separated the material into two different size classes with large or small ovigerous females, but then could not find any clearcut morphological definition which would not show here or there intermediate structures. Unfortunately, we have no clue about the life span of these females and how often they become ovigerous, thus all the observed tiny differences could also be due to allometry. 
Therefore we kept the locality citations separated and first gave information about the smaller specimens, followed by the larger ones. This might help to continue gathering observations within this so puzzling genus.

\section{Diagnosis for the material of 6-14 mm length}

Eyes big, round. Mandibular palp ratio art. 3:art. $2=0.6 . \mathrm{Cx} 3$ tongue-shaped rounded, smooth. Gn 1 propodus $1: \mathrm{w}=5$, dactylus reaching $1 / 4-1 / 3$ of propodus length. P 5-7 basis narrow oval, P 5, 6 with slightly concave hind margin, P 7 hind margine serrate, ratio 1:w about 2. Ep 2, 3 posterodistally with small rounded upturned corner. $\mathrm{T} 1 \mathrm{w} \mathrm{w}=3$.

\section{Additional smaller specimens}

\section{Australian Museum, Sydney}

P. 25977: 1 Feb. 1971; Ross Sea, Ross Island, Cape Bird, Southern Rookery; $77.2^{\circ} \mathrm{S}, 166.4^{\circ} \mathrm{E} ; 83 \mathrm{~m}$ depth: 1 spec. $10 \mathrm{~mm}$.

P. 25978: sta. C3-C4; 14 Dec. 1971; Ross Sea, Ross Island, Cape Bird, Southern Rookery; $77.2^{\circ} \mathrm{S}$, $166.4^{\circ} \mathrm{E} ; 85 \mathrm{~m}$ depth; spionid polychaete bottom: $1 \mathrm{spec} .14 \mathrm{~mm}$.

P. 25979: 30 Jan. 1971; Ross Sea, Ross Island, Cape Bird, Southern Rookery; $77.2^{\circ} \mathrm{S}, 166.4^{\circ} \mathrm{E} ; 61 \mathrm{~m}$ depth: 3 spec. $10 \mathrm{~mm}, 9 \mathrm{~mm}, 6 \mathrm{~mm}$.

P. 25980: sta. R13; 9 Feb. 1971; Anvers Island, Arthur Harbour; $64.8^{\circ} \mathrm{S}, 64.1^{\circ} \mathrm{W} ; 23 \mathrm{~m}$ depth; sand $50 \%$, silt $44 \%$, clay $7 \%$ : $1 \mathrm{spec} .6 .5 \mathrm{~mm}$.

P. 25981: sta. R13; 9 Feb. 1971; Anvers Island, Arthur Harbour; $64.8^{\circ} \mathrm{S}, 64.1^{\circ} \mathrm{W} ; 23 \mathrm{~m}$ depth; sand $49.9 \%$, silt $43.78 \%$, clay $7.14 \%$ : 1 spec. $7 \mathrm{~mm}$.

P. 34272: 8 Jan. 1982; Davis Station; $68.6^{\circ} \mathrm{S}, 78^{\circ} \mathrm{E}$; $15 \mathrm{~m}$ depth; rock and silt: 1 spec. $13 \mathrm{~mm}, 1$ juv.

P. 81141: 14 Jan. 1971; Ross Sea, MacMurdo Sound, Ross Island, Cape Bird; $77.2^{\circ} \mathrm{S}, 166.4^{\circ} \mathrm{E} ; 110 \mathrm{~m}$ depth: 1 spec. $10 \mathrm{~mm}$.

\section{Belgian-Dutch Antarctic Expeditions}

(RBINS, Brussels: EABN 1966-67, coll. M. Steyaert \& M. Meisch, RBINS I.G. 23694)

EABN 1966-67: sta. 220; 3 Feb. 1967; Breidbay, Baie Léopold; 70¹9’S, 24¹4’E; 200 m: 2 spec. 13 and $14 \mathrm{~mm}$.

EABN 1966-67: sta. 236; 3 Feb. 1967; Breidbay, Baie Léopold; 70¹9’S, 2414’'E; 200 m: 1 spec. $12 \mathrm{~mm}$.

\section{British Antarctic Survey, Cambridge}

Sta. SG-EBS 3-5; 5 Apr. 2006; South Georgia; 54²15's 36² $45^{\prime} \mathrm{W}$; 300-500 m: 1 spec. 6 mm.

\section{NIWA, Wellington}

NIWA 20425: sta. Tangaroa TAN 0402/15; 5 Feb. 2004; north-eastern Ross Sea, near Cape Adare; $71.7278^{\circ} \mathrm{S}, 171.7353^{\circ} \mathrm{E}$ to $71.7308^{\circ} \mathrm{S}, 171.7445^{\circ} \mathrm{E}$; $466-467 \mathrm{~m}: 1 \mathrm{spec} .11 \mathrm{~mm}$.

NIWA 20427: sta. Tangaroa TAN 0402/54; 13 Feb. 2004; north-eastern Ross Sea; $72.3248^{\circ} \mathrm{S}, 170.4277^{\circ} \mathrm{E}$ to $72.3315^{\circ} \mathrm{S}, 170.4287^{\circ} \mathrm{E} ; 206-199 \mathrm{~m} ; 1$ spec. $13 \mathrm{~mm}$

NIWA 20428: sta. Tangaroa TAN 0402/94; 17 Feb. 2004; north-eastern Ross Sea; $71.5299988^{\circ} \mathrm{S}$, $170.1109924^{\circ} \mathrm{E}$ to $71.5234985^{\circ} \mathrm{S}, 170.1131744^{\circ} \mathrm{E} ; 220-191 \mathrm{~m} ; 1$ spec. $11 \mathrm{~mm}$.

NIWA 20873: sta. Tangaroa TAN 0402/14; 5 Feb. 2004; north-eastern Ross Sea; $71.7313309^{\circ} \mathrm{S}$, $171.7500000^{\circ} \mathrm{E} ; 451 \mathrm{~m}: 1 \mathrm{spec} .9 \mathrm{~mm}$,

NIWA 20874: sta. Tangaroa TAN 0402/129; 19 Feb. 2004; north-eastern Ross Sea; $71.3268356^{\circ} \mathrm{S}$, $170.4515076^{\circ} \mathrm{E}$ to $71.3268356^{\circ} \mathrm{S}, 170.4515076^{\circ} \mathrm{E}, 120 \mathrm{~m}, 1$ spec. $10 \mathrm{~mm}$,

NIWA 21022: sta. Tangaroa TAN 0402/111; 18 Feb. 2004; north-eastern Ross Sea; $71.3044968^{\circ} \mathrm{S}$ $170.6179962^{\circ} \mathrm{E} ; 357 \mathrm{~m}: 1$ spec. $10 \mathrm{~mm}$. 


\section{Polarstern cruises}

(ANT VII/4 (EPOS 3), coll. C. De Broyer \& M. Klages, RBINS I.G. 27497; ANT XIII/3 (EASIZ I), coll. C. De Broyer \& G. Chapelle, RBINS I.G. 28252; ANT XV/3 (EASIZ II), coll. C. De Broyer \& Y. Scailteur, RBINS I.G. 28252; ANT XXI/2 (BENDEX), coll. C. De Broyer, RBINS I.G. 31072; ANT XXIII-8, coll. C. d'Udekem d'Acoz \& H. Robert, RBINS I.G. 31070)

ANT VII/4 (EPOS 3): sta. PS14/245 GSN9; 2 Feb. 1989; eastern Weddell Sea; 7440’S, 2940’W; $483 \mathrm{~m}$; bottom trawl: 3 spec. $14 \mathrm{~mm}$; 2 smaller ones.

ANT VII/4 (EPOS 3): sta. PS14/245 AGT9; 2 Feb. 1989; eastern Weddell Sea; 7440'S, 2942'W; $509 \mathrm{~m}$; Agassiz Trawl: 1 spec. \& $12 \mathrm{~mm}$.

ANT XIII/3 (EASIZ I): sta. PS39/006 AGT1; 8 Feb. 1996; eastern Weddell Sea; 71³1'S, 1334'W to 71 ${ }^{\circ} 31^{\prime} \mathrm{S} 13^{\circ} 35^{\prime} \mathrm{W}$; 254-261 m; Agassiz Trawl: 2 spec. 11 and $13 \mathrm{~mm}$ and one damaged.

ANT XIII/3 (EASIZ I): sta. PS39/011 GSN4; 13 Feb. 1996; eastern Weddell Sea; 73²2'S, $21^{\circ} 10^{\prime} \mathrm{W}$ to $73^{\circ} 23^{\prime} \mathrm{S}, 21^{\circ} 12^{\prime} \mathrm{W}$; 333-338 m; bottom trawl: 1 spec. $14 \mathrm{~mm}$ with orange spots.

ANT XIII/3 (EASIZ I): sta. PS39/016 GSN; 15 Feb. 1996; eastern Weddell Sea; 7353,40’S, 22²6,90’W; $246 \mathrm{~m}$; bottom trawl: $1 \mathrm{spec} .11 \mathrm{~mm}$.

ANT XIII/3 (EASIZ I): sta. PS39/026 D; 24 Feb. 1996; eastern Weddell Sea, 71 ${ }^{\circ} 29^{\prime} \mathrm{S}, 14^{\circ} 19^{\prime} \mathrm{W}$ to 7129’S, $14^{\circ} 19^{\prime} \mathrm{W}$; 210-214 m; dredge 21; coll. Rauschert: 2 spec.

ANT XV/3 (EASIZ II): sta. PS48/044 AGT; 30 Jan. 1998; eastern Weddell Sea, north of Kapp Norvegia; 7051'48”'S, 10³4'W to 7051'54'S, 10³3'48”'W; 227-229 m; Agassiz Trawl: 1 spec. $14 \mathrm{~mm}$.

ANT XV/3 (EASIZ II): sta. PS48/049 AGT; 30 Jan. 1998; eastern Weddell Sea; 7052’S, 10²7’18”'W to 7051'54'’S, 10²6'48’'W; 255-261 m; Agassiz Trawl: 1 spec. $12 \mathrm{~mm}$.

ANT XV/3 (EASIZ II): sta. PS48/077 AGT; 2 Feb. 1998; eastern Weddell Sea; 7109'42”S, 12²8'42”W to $71^{\circ} 09^{\prime} 54^{\prime \prime} \mathrm{S}, 12^{\circ} 29^{\prime} 12^{\prime \prime} \mathrm{W}$; 341-360 m; Agassiz Trawl: 1 spec. $13 \mathrm{~mm}$.-

ANT XV/3 (EASIZ II): sta. PS48/078 GSN; 3 Feb. 1998; eastern Weddell Sea; 7251'06”S, $19^{\circ} 15^{\circ} 06$ ”'W to $72^{\circ} 50^{\prime} 54^{\prime \prime} \mathrm{S}, 19^{\circ} 18^{\prime} 42^{\prime \prime} \mathrm{W}$; 390-391 m; bottom trawl: o $14 \mathrm{~mm}$, with orange spots in alcohol.

ANT XV/3 (EASIZ II): sta. PS48/082 GSN; 3 Feb. 1998; eastern Weddell Sea, Drescher Inlet;

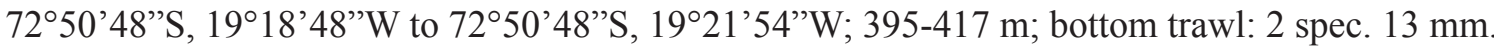

ANT XV/3 (EASIZ II): sta. PS48/154 GSN; 11 Feb. 1998; eastern Weddell Sea, Halley Bay; 74³8'42”'S, $26^{\circ} 59^{\prime} \mathrm{W}$ to $74^{\circ} 39^{\prime} 12^{\prime \prime} \mathrm{S}, 27^{\circ} 01^{\prime} 12^{\prime \prime} \mathrm{W}$; $569-583 \mathrm{~m}$; bottom trawl: 3 spec. $10-13 \mathrm{~mm}$.

ANT XV/3 (EASIZ II): sta. PS48/206 GSN; 18 Feb. 1998; eastern Weddell Sea, Kapp Norvegia;

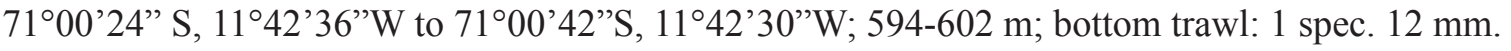

ANT XV/3 (EASIZ II): sta. PS48/222 GSN; 19 Feb. 1998; eastern Weddell Sea, Kapp Norvegia;

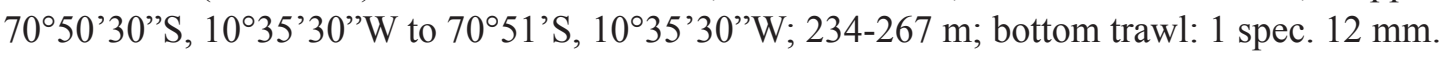

ANT XXI/2 (BENDEX): sta. PS65/29 AGT; 25 Nov. 2003; Bouvet Island; 54³1,59’S, 03¹3,05'E; $377 \mathrm{~m}$; Agassiz Trawl; in sponge, $56 \mathrm{~m}$ : 2 spec. 10 and $12 \mathrm{~mm}$.

ANT XXIII/8, sta. PS69/RD 726-1; 23 Jan. 2007; Snow Hill Island; 64³0.86’S, 56 40.23’W; 197 m; Rauschert dredge; + ov. $14 \mathrm{~mm}, 2$ spec. $12 \mathrm{~mm}$.

\section{Description}

\section{Length}

Up to $14 \mathrm{~mm}$

\section{Head}

Anterior margin rounded, anterodistal margin rectangular with rounded corner. Mid-cephalic keel prominent. Rostrum small, curved.

Eyes large, round. 
Antenna 1 one third of body length, flagellum 10-14-articulate, peduncle art. 1 width proximally less than twice article 2, disto-inferiorly without acute tooth, length art. 1 subequal art. 2, art. 3 about 1/2 of art. 2, acc. flagellum not seen. Peduncle art. 3 + flagellum shorter than peduncle arts $1+2$.

Antenna 2 subequal in length with antenna 1, peduncle art. 4 clearly longer art. 5, flagellum 9-10 arts.

Mouthparts: Mandibles lacking molars, incisor and lacinia mobilis dentate; palp 3-articulate, art. 2 with many lateral setae of different length, art. 3 with 2 distal setae, art. $3>1 / 2$ art. 2. Maxilliped IP small, OP very short; palp articles similar in length.

\section{Peraeon}

Cx 1 smooth, length > width; anterior margin smooth, facial setae absent, inferior margin smooth.

Gn 1 basis not inflated, both margins with short setae; carpus basis more than half as long as propodus, distal part linear and narrow, about $10 \mathrm{x}$ longer than wide; propodus straight, about $5 \mathrm{x}$ as long as wide, palm minutely dentate with 9 short setae; dactylus smooth, reaching up to $1 / 3$ propodus length.

Cx 2 subquadrangular, about as long as wide, much wider than $\mathrm{Cx} 3$, distally smooth; anterior margin convex, anterodistal corner rectangular, inferior margin straight, facial setae absent.

Gn 2 basis scarcely inflated, many short setae on anterior margin; carpus nearly reaching half propodus length, curved, distally truncate, densely setose; propodus anterodistally with short prolongation and a bundle of setae, posterior margin with many low humps, palm convex, proximally near dactylus-end no corner; dactylus curved, both margins smooth, bare, reaching more than half of propodus length.

Cx 3 length > width, distally obliquely rounded, tongue-shaped, smooth, facial setae absent.

Cx 4 length subequal to width, smooth, bare, anterior margin convex, distal margin rounded, posterior margin shorter than anterior one, excavate, facial setae absent.

P 3, 4 basis very narrow, a bit wider than merus; dactylus reaching less than half length of propodus, posterior margins with some short thin spines.

Cx 5-7 facial setae absent.

P 5-7 similar, bases 1:w ratio up to 2, anterior margins with very slight serrations and small weak spines, posterior margins in P 5, 6 smooth, in P 7 weakly. Merus in P 5-7 with posterodistal corner lengthened.

\section{Pleon}

Ep 1-3 without spines or setae. Ep 2 posteroventral corner not acutely upturned, but produced with rounded corner, Ep 3 posteroventral corner blunt and rectangular.

Uropods: U 1 with somewhat unequal rami, the shorter one shorter than peduncle; $\mathrm{U} 2$ the shortest, with unequal rami, the shorter one subequal to peduncle; $\mathrm{U} 3$ with equal rami much shorter than peduncle.

Telson ratio $1: \mathrm{w}=3$.

No sexual difference noticed.

\section{Distribution}

Circum-Antarctic $\left(54^{\circ}-77^{\circ} \mathrm{S}, 10^{\circ}-64^{\circ} \mathrm{W}\right.$ and $\left.03^{\circ}-171^{\circ} \mathrm{E}\right)$. 


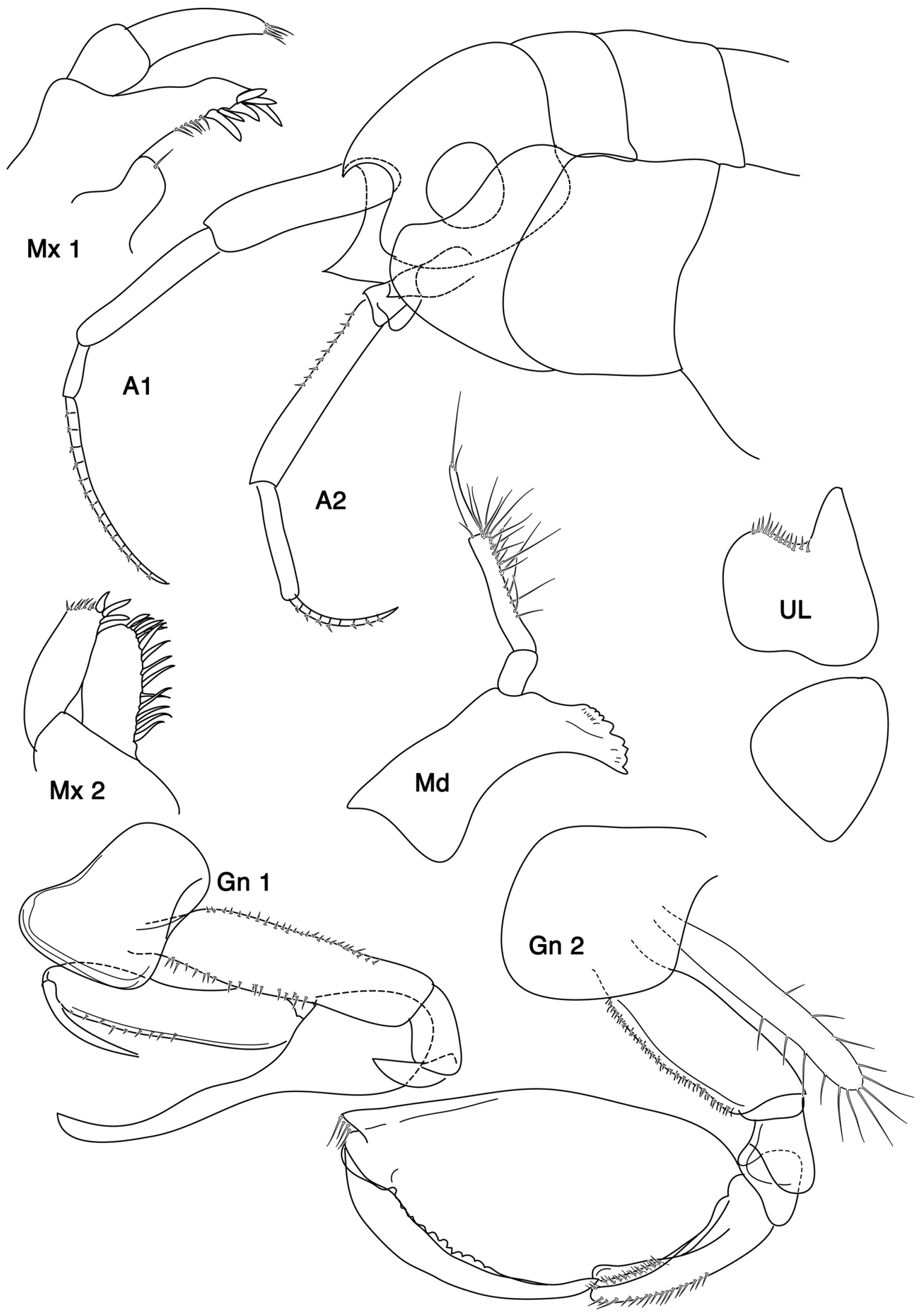

Fig. 19. Leucothoe weddellensis sp. nov., $14 \mathrm{~mm}$. A 1, $2=$ antenna 1, 2; UL = upper lip; Mx 1, 2 $=$ maxilla 1,$2 ; \mathrm{Md}=$ mandible; $\mathrm{Gn} 1,2=$ gnathopod 1,2 . 


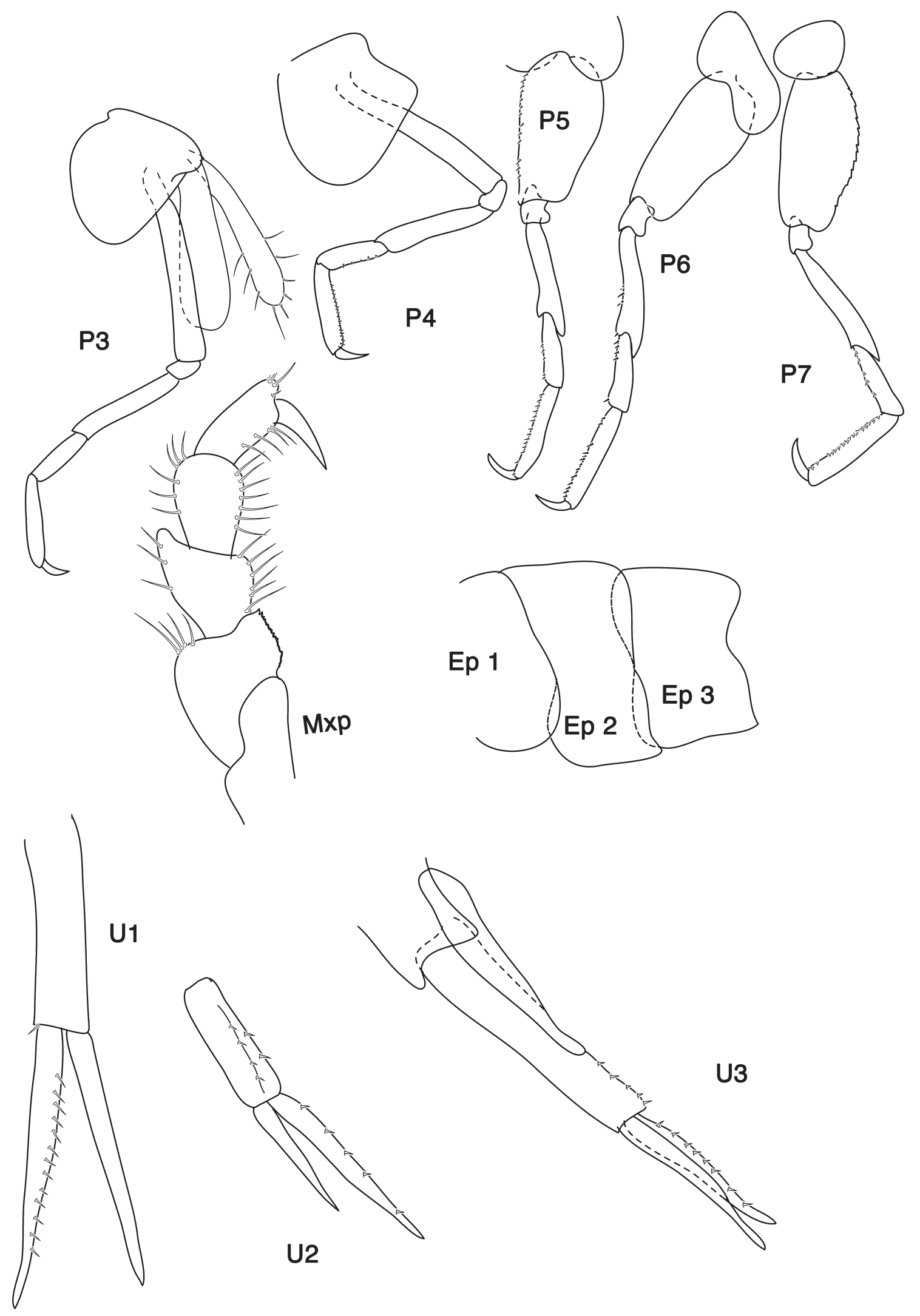

Fig. 20. Leucothoe weddellensis sp. nov., $q 14 \mathrm{~mm}$. P 3-7 = peraeopod 3-7; Mxp = maxilliped; Ep 1-3 $=$ epimeral plate $1-3 ; \mathrm{U} 1-3=\operatorname{uropod} 1-3$. 


\section{Depth range}

15-602 m.

\section{Remarks}

In Holman \& Watling (1983: 227, fig. 11: upper part, L. spinicarpa variant 2) only few sketches of females of 6-6.5 mm are given which could match the here described specimens of 10-14 mm. On p. 229 the authors wrote: "[...] smaller specimens [in comparison to the following species of $20 \mathrm{~mm}$ ] tending not to have this tooth [on Ep 3 posterodistal corner] or distinctive shape of Cx 3.[...] At stations where both variants 1 and 2 occurred, there is also a clear size dichotomy."

\section{Diagnosis for the material of 14-24 mm length}

Eyes large, round. Cephalic keel acute. Mandibular palp ratio art. 3:art. $2=0.3$. Cx 3 in large specimens distal margin excavate, posterodistal corner lengthened and tongue-shaped rounded, smooth, in smaller ones without this character. Gn 1 propodus 1:w $=5-6$, dactylus reaching 0.4 of propodus length. P 5-7 basis pear-shaped oval, all with convex and serrate hind margin, ratio length to width 1.7-1.8. Ep 1 posterior margin serrate, Ep 2 posterodistally with acutely lengthened but not much upturned corner, Ep 3 posteriordistal corner rectangular, with small prolongation. $\mathrm{T}$ 1:b $=3$.

\section{Additional larger size material}

\section{NIWA, Wellington}

NIWA 9062: sta. LOCVI-2; Ross Sea, west to Beaufort Island; $77.8327789^{\circ} \mathrm{S}, 166.6138916^{\circ} \mathrm{E} ; 28$ Dec. 1959, 9-19 m, 1 spec. 15 mm,

NIWA 17881: Tangaroa sta. TAN 0402/53; 13 Feb. 2004; north-eastern Ross Sea; $72.3310013^{\circ} \mathrm{S}$, $170.4278259^{\circ} \mathrm{E} ; 197 \mathrm{~m}: 1$ ?juv. $10 \mathrm{~mm}$.

NIWA 20426: Tangaroa sta. TAN 0402/67; 13 Feb. 2004; north-eastern Ross Sea; $72.3209991^{\circ} \mathrm{S}$, $170.4751740^{\circ} \mathrm{E}$ to $72.3345032^{\circ} \mathrm{S} 170.4813385^{\circ} \mathrm{E} ; 272-286 \mathrm{~m}: 1 \mathrm{spec} .13 \mathrm{~mm}$

NIWA 20429: Tangaroa sta. TAN 0402/108; 18 Feb. 2004; north-eastern Ross Sea; $71.2718353^{\circ} \mathrm{S}$, $170.5996704^{\circ} \mathrm{E}$ to $71.2773361^{\circ} \mathrm{S} 170.6151733^{\circ} \mathrm{E}$; $400-405 \mathrm{~m}$ : 1 spec. $13 \mathrm{~mm}$,

NIWA 20430: Tangaroa sta. TAN 0402/112; 18 Feb. 2004; north-eastern Ross Sea; $71.2935028^{\circ} \mathrm{S}$, $170.5766602^{\circ} \mathrm{E}$ to $71.2961655^{\circ} \mathrm{S} 170.5908356^{\circ} \mathrm{E} ; 346-351 \mathrm{~m}$ : 1 spec. $17 \mathrm{~mm}$.

NIWA 20431: Tangaroa sta. TAN 0402/133; 23 Feb. 2004; north-eastern Ross Sea; $71.6446686^{\circ} \mathrm{S}$, $170.2188263^{\circ} \mathrm{E}$ to $71.6470032^{\circ} \mathrm{S} 170.2243347^{\circ} \mathrm{E} ; 249-252 \mathrm{~m}: 1 \mathrm{spec} .15 \mathrm{~mm}$.

\section{Polarstern cruises}

(ANT XV/3 (EASIZ II), coll. C. De Broyer \& Y. Scailteur, RBINS I.G. 28252; ANT XIX/3 (ANDEEP I), coll. C. De Broyer, P. Dauby \& F. Nyssen, I.G. 31073)

ANT XV/3 (EASIZ II): sta. PS48/078 GSN; 3 Feb. 1998; eastern Weddell Sea; 7251'06”S, 19¹5’06”W to $72^{\circ} 50^{\prime} 54^{\prime \prime} \mathrm{S}, 19^{\circ} 18^{\prime} 42^{\prime \prime} \mathrm{W}$; $390-391 \mathrm{~m}$; bottom trawl: Oे $^{16} \mathrm{~mm}$, with orange spots.

ANT XV/3 (EASIZ II): sta. PS48/062 AGT; 31 Jan. 1998; eastern Weddell Sea; 7053’36”S, 10²8'06”'W to $70^{\circ} 53^{\prime} 42^{\prime \prime S}, 10^{\circ} 28^{\prime} 12^{\prime \prime} \mathrm{W}$; 235-241 m; Agassiz Trawl: 1 spec. $12 \mathrm{~mm}$ in 3 slides, 2 spec. $13 \mathrm{~mm}$, $20 \mathrm{~mm}$, all without eggs.

ANT XIX/3 (ANDEEP I): sta. PS61/047-I; 30 Jan. 2002; north of Elephant Island; $61^{\circ} 04,18^{\prime}$ S, 54³6,81’W; $190 \mathrm{~m}$; bottom trawl: 9 spec. $18-20 \mathrm{~mm}$.

ANT XIX/3 (ANDEEP I): sta. PS61/048-1; 30 Jan. 2002; east of Elephant Island; 61 $09,82^{\prime}$ S, 543ㅜㄴ, $40^{\prime} \mathrm{W}$; $343 \mathrm{~m}$; bottom trawl: $1 \mathrm{spec} .20 \mathrm{~mm}$.

ANT XIX/3 (ANDEEP I): sta. PS61/067 GSN; 4 Feb. 2002; north of Elephant Island; 6055'53”S, $55^{\circ} 27^{\prime} 38^{\prime \prime} \mathrm{W}$ to $60^{\circ} 55^{\prime} 09^{\prime} \mathrm{S}, 55^{\circ} 24^{\prime} 50^{\prime \prime} \mathrm{W}$; 115-182 m; bottom trawl: 1 spec. $20 \mathrm{~mm}$. 


\section{Polish Antarctic Expeditions (LPBO-UL, Lódź)}

Polish Ant. Exp. 2007, sta. Profile B II/4; 27 Mar. 2007; King George Island, Admiralty Bay; 6209,643’'S, 58`30,182’W; 112 m; Van Veen Grab;1 spec. 19 mm.

Polish Ant. Exp. 2007, sta. Profile B I/1; 27 Mar. 2007; King George Island, Admiralty Bay; 6209, 703’S, 58³0,272’W; 109 m; Van Veen Grab: 1 spec. 10 mm.

\section{Victoria Museum, Melbourne}

J 38264: Aurora Australis, sta.AA93-127; Lot 414; 12 Feb. 1993, 67²16.12'S, 65²5.23’E; Mac Robertson Shelf, edge of Nielsen Basin; 109 m: 1 ov. $q 15$ mm.

\section{Description}

\section{Length}

Up to $24 \mathrm{~mm}$.

\section{Head}

Anterior margin rounded, anterodistal margin rectangular with rounded corner. Mid-cephalic keel acute. Rostrum small, curved.

Eyes large, round.

Antenna 1 one third of body length, flagellum 20 -articulate, peduncle art. 1 width proximally less than twice article 2, distally without acute tooth, length art. $1>$ art. 2, art. 3 about 1/3 of art. 2, acc. flagellum not seen. Peduncle art. $3+$ flagellum shorter than peduncle arts $1+2$.

Antenna 2 subequal in length to antenna 1, peduncle art. 4 clearly longer art. 5, flagellum 10-16 arts.

Mouthparts: Mandibles lacking molars, incisor and lacinia mobilis dentate; palp 3-articulate, art. 2 with many lateral and some distal setae of different length, art. 3 with 3 distal setae, art. $3=1 / 2$ art. 2 . Maxilliped IP small, OP absent; palp articles similar in length.

\section{Peraeon}

Cx 1 smooth, length = width; anterior margin smooth, facial setae absent, inferior margin smooth.

Gn 1 basis not inflated, both margins smooth; carpus basis about half as long as propodus, distal part linear and narrow, about $8 \times$ longer than wide; propodus straight, about

$4.5 \mathrm{x}$ as long as wide, palm smooth with 7-8 short setae; dactylus smooth, reaching 2/5 propodus length.

Cx 2 subquadrangular, about as long as wide, much wider but shorter than $\mathrm{Cx} 3$, distally smooth; anterior margin convex, anterodistal corner rectangular, inferior margin straight, facial setae absent.

Gn 2 basis not inflated, many short setae on anterior margin; carpus nearly reaching half propodus length, curved, distally excavate in male, rounded in female, densely setose; propodus anterodistally with short, acute prolongation and a bundle of setae, posterior margin with many low humps, palm convex, proximally near dactylus-end no corner; dactylus curved, both margins smooth, bare, reaching more than half of propodus length.

Cx 3 length $>$ width, anterior and posterior margin straight, distal margin oblique and excavate, posterodistal corner in large animals tongue-shaped and lengthened, smooth, facial setae absent. 


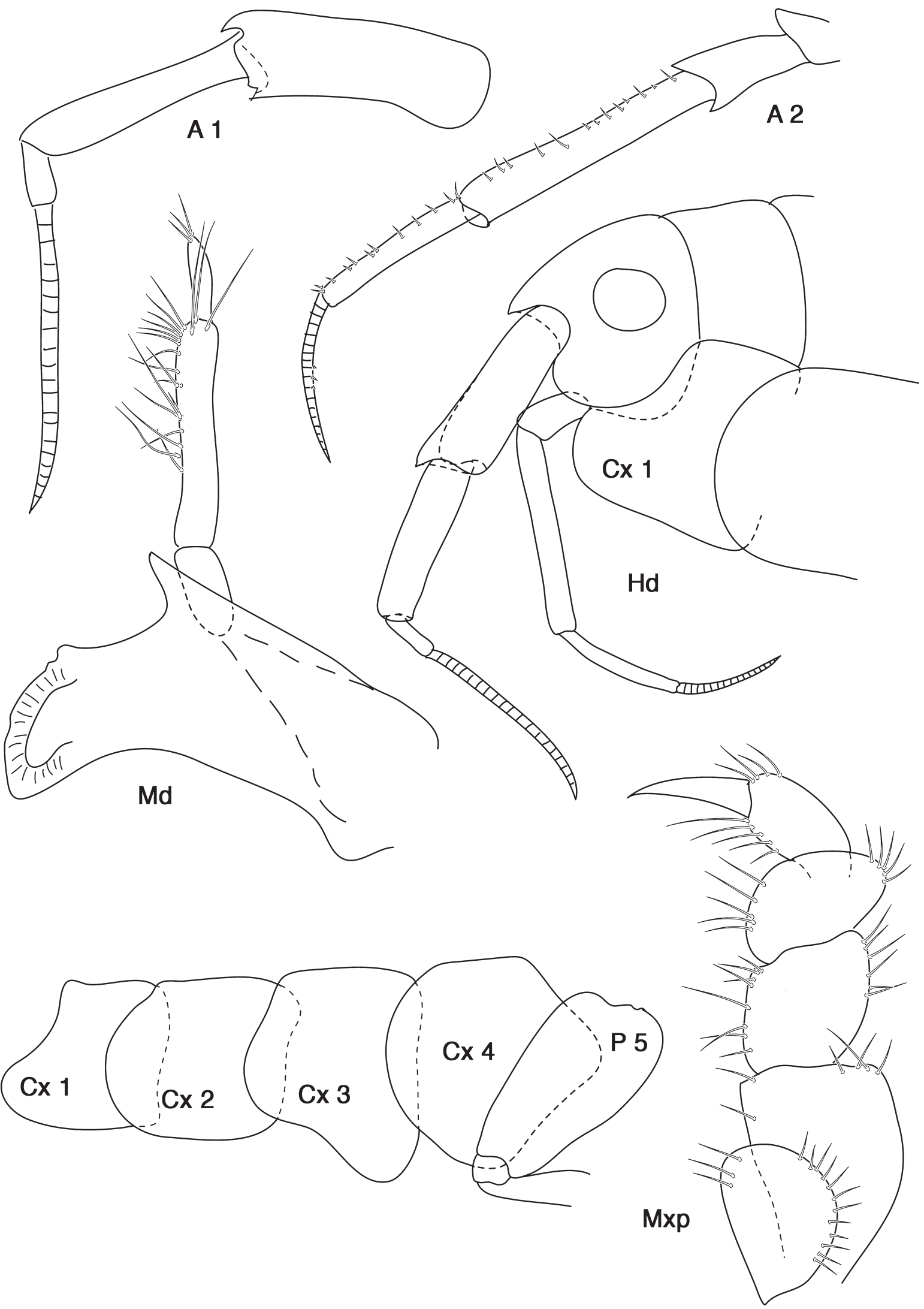

Fig. 21. Leucothoe weddellensis sp. nov., $q 20 \mathrm{~mm}$. A 1, 2 = antenna 1,2. $\mathrm{Hd}=$ head; $\mathrm{Md}=$ mandible; $\mathrm{Mxp}=$ maxilliped; Cx 1-4 = coxa 1-4. 


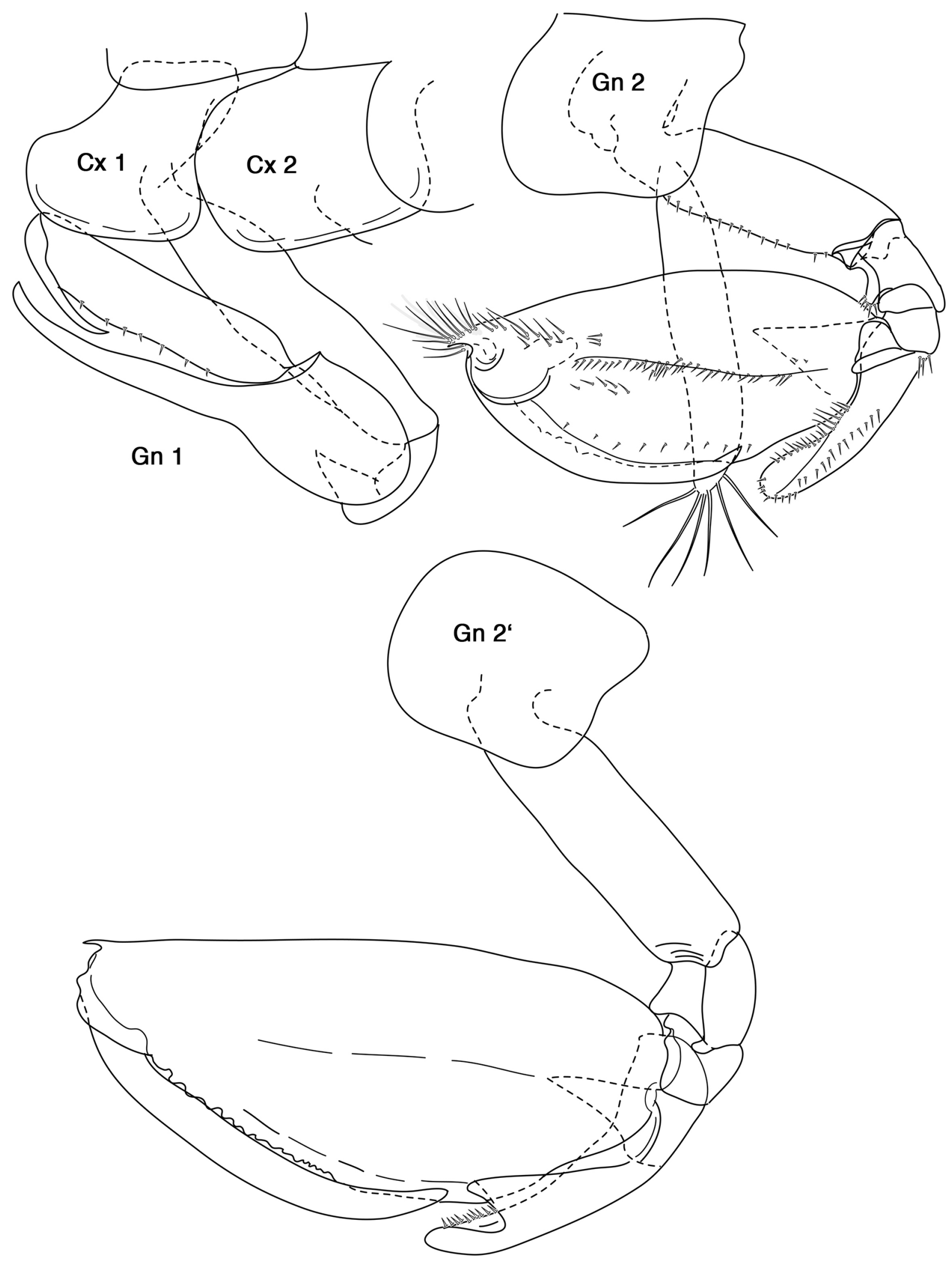

Fig. 22. Leucothoe weddellensis sp. nov., q $20 \mathrm{~mm}$. Cx 1, $2=\operatorname{coxa} 1,2$; Gn 1, $2=\operatorname{gnathopod~1,~2;~}$ Gn 2' = second gnathopod of $\partial^{\lambda} 20 \mathrm{~mm}$. 

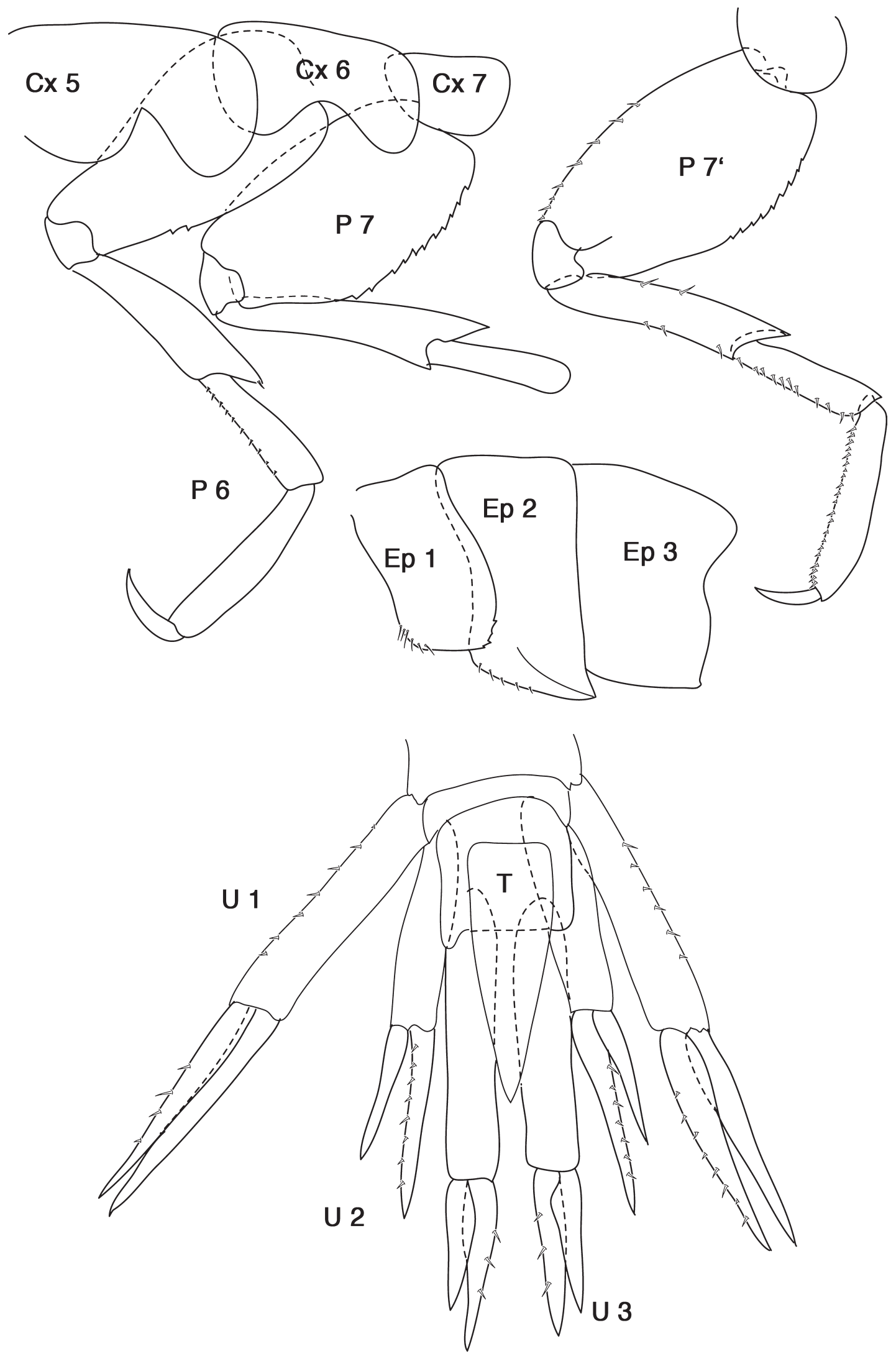

Fig. 23. Leucothoe weddellensis sp. nov., q $20 \mathrm{~mm}$. Cx 5-7 = coxa 5-7; P 6-7 = peraeopod 6, 7; P 7' $=$ peraeopod 7 of other specimen; Ep 1-3 = epimeral plates 1-3; U 1-3 $=\operatorname{uropod} 1-3 ; \mathrm{T}=$ telson. 


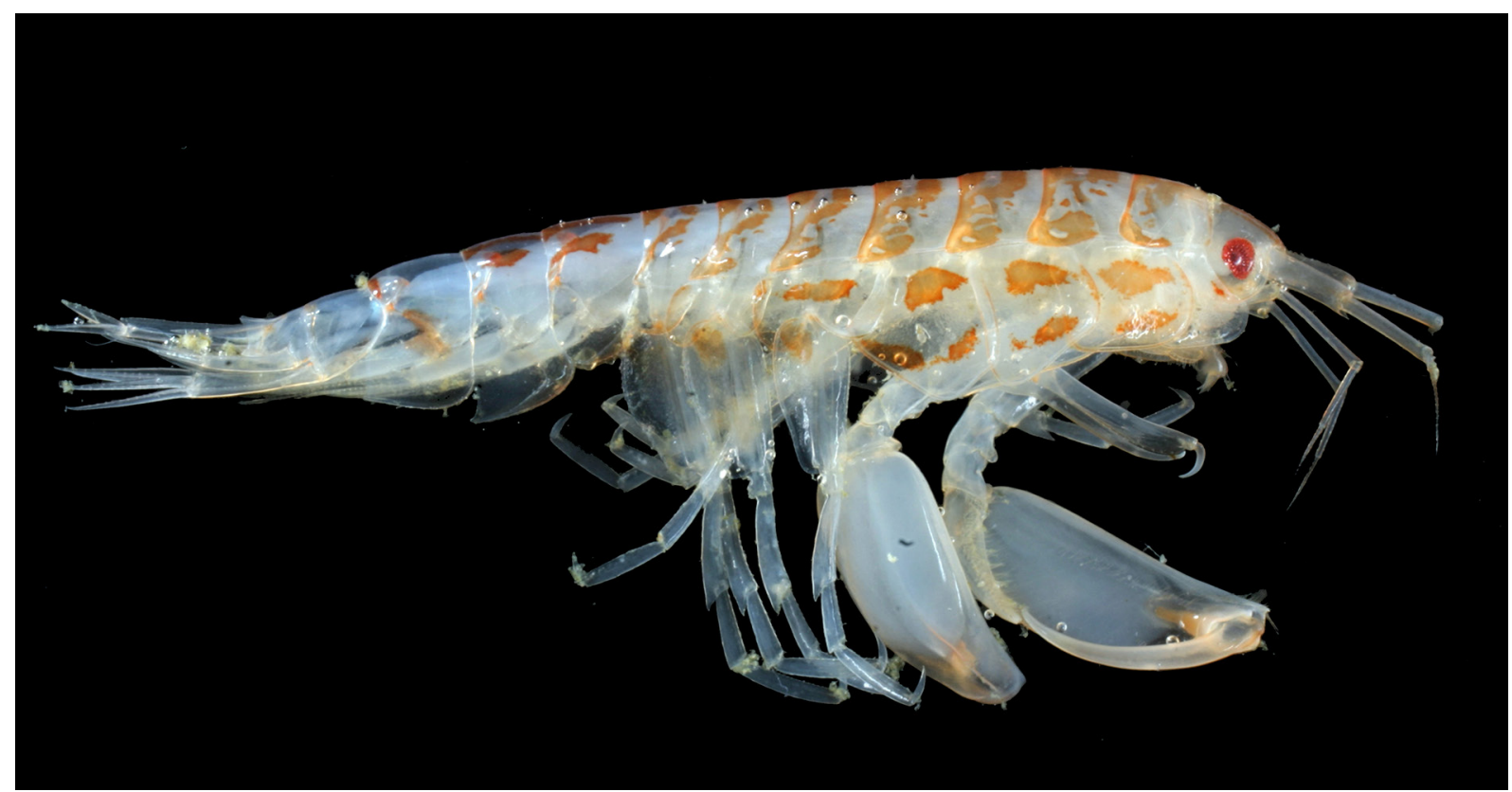

Fig. 24. Leucothoe weddellensis sp. nov., colour photo by Martin Rauschert: Polarstern ANT XXI/2 (BENDEX): St. PS65/281; 29 Dec. 2003; eastern Weddell Sea, off Kapp Norvegia; 71³,32’S, $11^{\circ} 28,45^{\prime} \mathrm{W}$; $82 \mathrm{~m}$; Rauschert dredge: spec. $20 \mathrm{~mm}$.

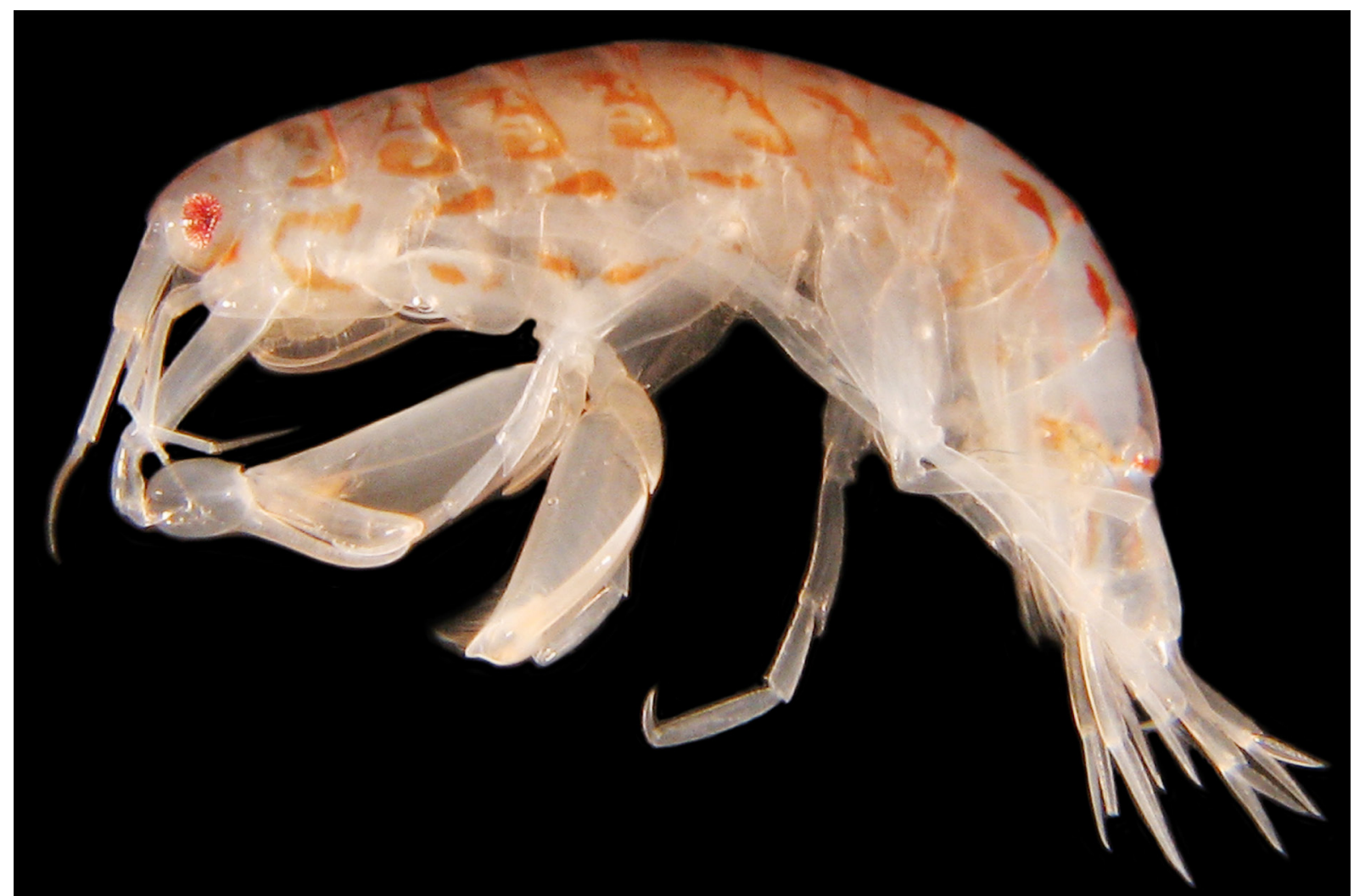

Fig. 25. Leucothoe weddellensis sp. nov., colour photo by Cédric d'Udekem d'Acoz: Polarstern ANT XXIII/8, sta. PS69/RD 726-1; 23 Jan. 2007; Snow Hill Island; 64³0.86’S, 56 40.23’W; 197 m; Rauschert dredge: .. ov. $14 \mathrm{~mm}$. 
Cx 4 length subequal to width, smooth, bare, anterior margin rounded, distal margin straight to excavate, posterior margin shorter than anterior one, straight to slightly excavate, facial setae absent.

P 3, 4 basis very narrow, a bit wider than merus; dactylus reaching less than half length of propodus, posterior margins with some short thin spines.

Cx 5-7 facial setae absent.

P 5-7 similar, bases 1:w ratio 1.7-1.8, anterior margins with very small spines, posterior margins serrate. Merus in P 5-7 with posterodistal corner lengthened.

\section{Pleon}

Ep 1-2 with spines anterodistally. Ep 2 posteroventral corner not upturned, but produced with acute corner, Ep 3 posteroventral corner rectangular with small rounded prolongation.

Uropods: U 1 with equal rami, shorter than peduncle; $U 2$ the shortest, with unequal rami, the shorter one clearly shorter than peduncle; $U 3$ with slightly unequal rami much shorter than peduncle.

Telson ratio $1: \mathrm{w}=3$.

\section{Distribution of the larger specimens}

Circum-Antarctic $\left(60^{\circ}-78^{\circ} \mathrm{S}, 10^{\circ}-58^{\circ} \mathrm{W}\right.$ and $\left.65^{\circ}-170^{\circ} \mathrm{E}\right)$.

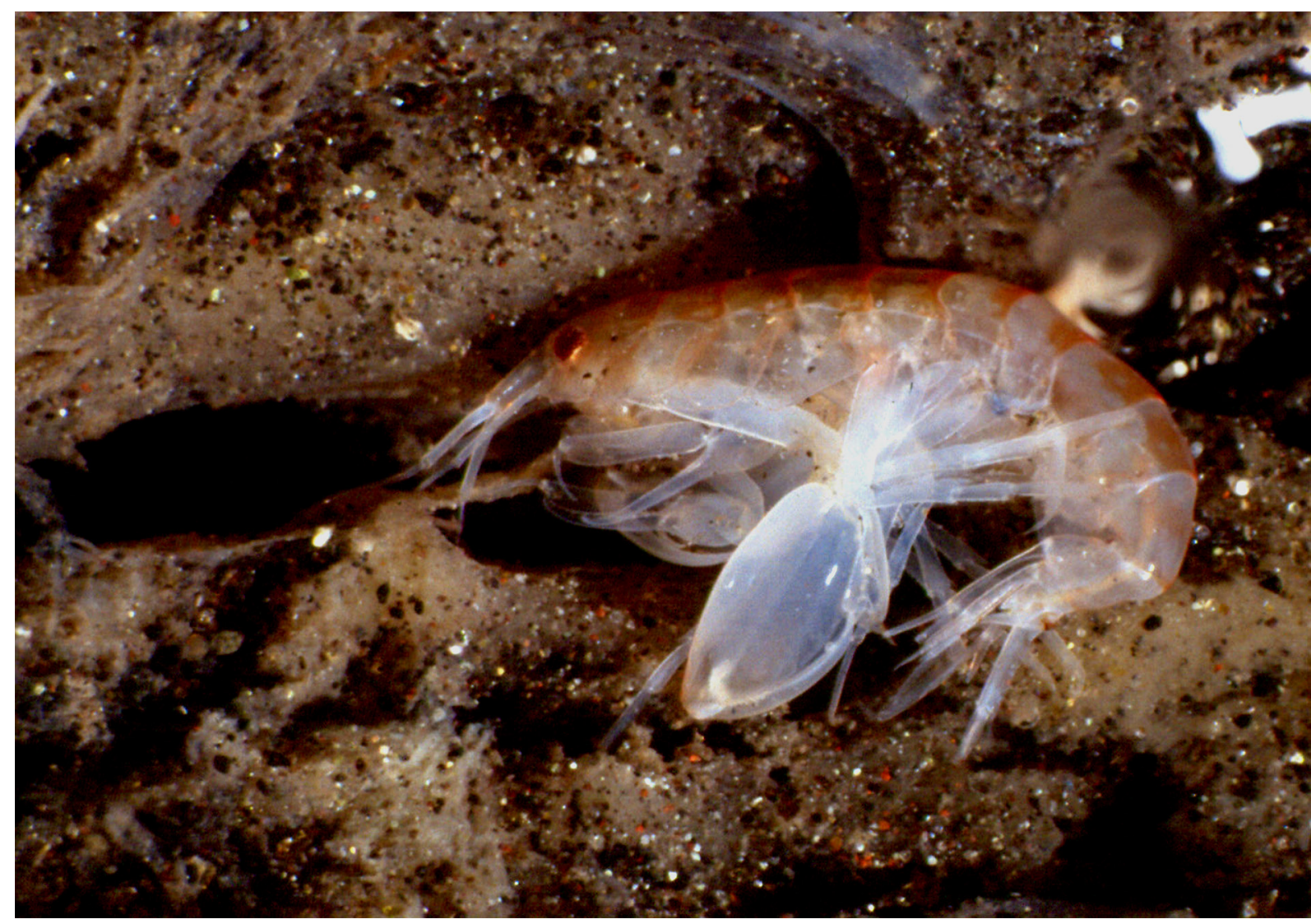

Fig. 26. Leucothoe weddellensis sp. nov., colour photo by Martin Rauschert: Polarstern ANT XXI/2 (BENDEX): St. PS65/29AGT; 25 Nov. 2003; Bouvet Island; 54³1.51'S, 03¹2.84'E; in sponge, 365 m; Agassiz trawl: spec. $12 \mathrm{~mm}$. 


\section{Depth range}

\section{$9-405 \mathrm{~m}$.}

Holman \& Watling (1983) recorded "L. spinicarpa variant 1" in the Drake Passage, south of Tierra del Fuego (Eltanin 9, sta. 740; 18 Sep. 1963; 56 06-07'S, 66 ${ }^{\circ} 19^{\prime}-30^{\prime} \mathrm{W} ; 384-494 \mathrm{~m}$ ), on the South Georgia

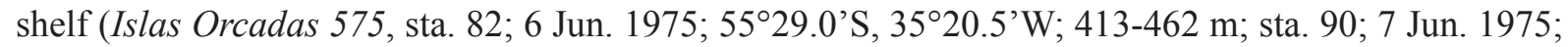
$54^{\circ} 50.6^{\prime} \mathrm{S}, 37^{\circ} 23.8^{\prime} \mathrm{W}$; $223-227 \mathrm{~m}$ ), in the Scotia Sea (Eltanin 6, sta. 410; 31 Dec. 1962; 61 ${ }^{\circ} 18^{\prime}-20^{\prime} \mathrm{S}$, $56^{\circ} 09^{\prime}-10^{\prime} \mathrm{W} ; 220-240 \mathrm{~m}$ ) and north of the Antarctic Peninsula (Eltanin 12, sta. 1003; 15 Mar. 1964; $\left.62^{\circ} 41^{\prime} \mathrm{S}, 54^{\circ} 43^{\prime} \mathrm{W} ; 210-220 \mathrm{~m}\right)$.

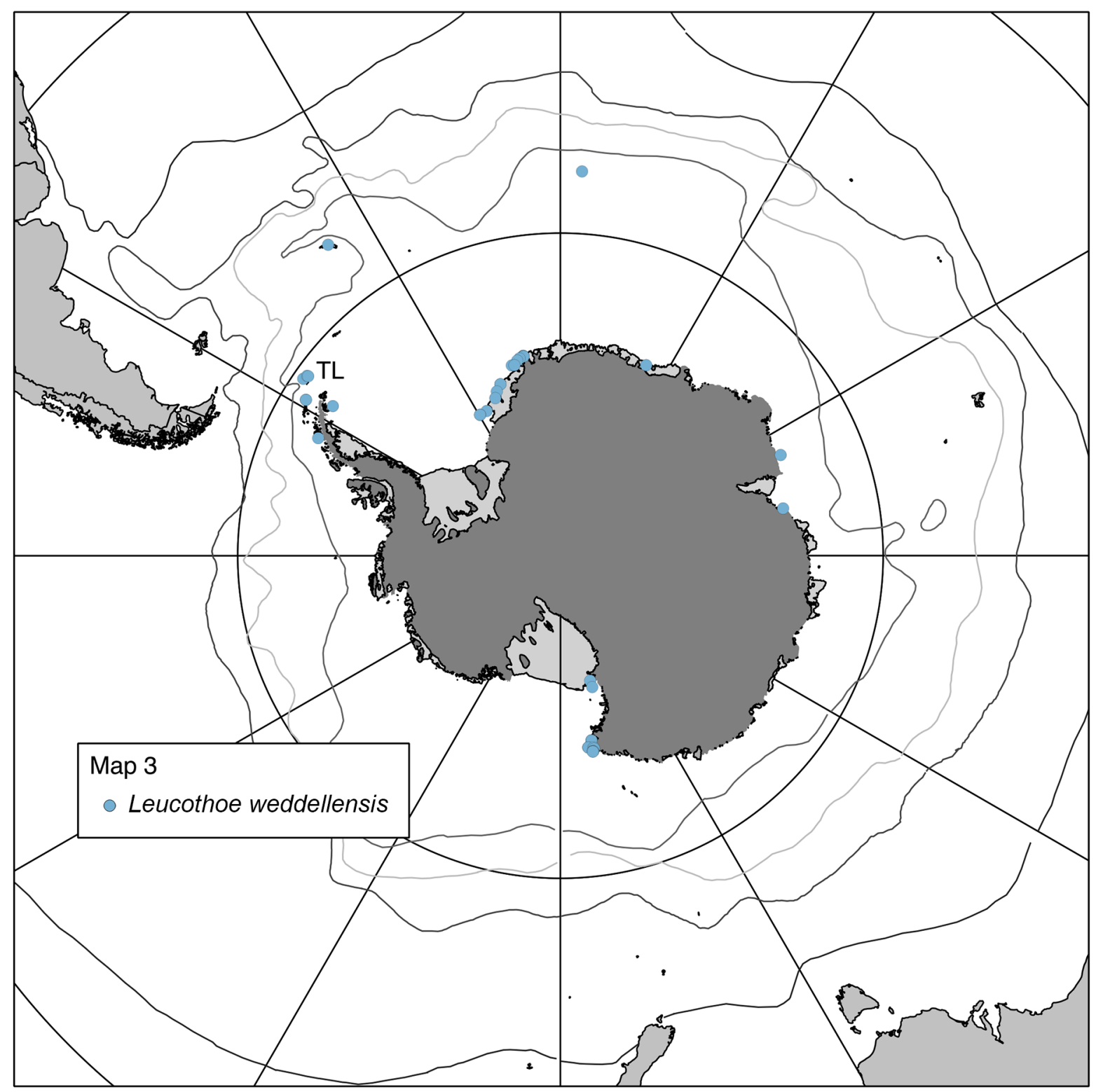

Fig. 27. Distribution of Leucothoe weddellensis sp. nov. Hydrographic fronts as in Fig. 5. TL = type locality. 


\section{Remarks}

In Holman \& Watling (1983: 227, Fig. 10) males are illustrated which are 19-24 mm long and match perfectly to the here illustrated material of $20 \mathrm{~mm}$. Holman \& Watling (1.c.: 229) defined their variant 1 as follows: “...ventral margin of coxa 3 bilobed in larger specimens, coxa 4 not excavate posteriorly. Gnathopod 1 very similar to that illustrated by Sars (1895) for L. spinicarpa, dactyl nearly half length and twice width of propodus, latter 5 times as long as wide. Gnathopod 2, distal margin of article 5 bifurcate in large males. Third epimeron posterodistal corner with small tooth but without distinct sinus above; however, smaller specimens tending not to have this tooth or distinctive coxa 3 shape...."

Differences to the smaller material are, besides the nearly double length of mature females, the length of Md palp art. 3 (we doubt that there can be such a strong allometry), the shape of Cx 3, P 5-7 basis and $\mathrm{U} 3$ rami. However, the main reason of our hesitation is that we found samples with both small and larger ovigerous females, and with larger specimens with and smaller ones without the characteristic shape of $\mathrm{Cx} 3$ living together.

Within all hitherto known Leucothoe species only L. serraticarpa Della Valle, 1893 has a distal lobation on a coxa in large specimens (like here on $\mathrm{Cx} 3$ ), but in the former it is in $\mathrm{Cx} 4$ and has a different shape.

\section{Discussion}

Widespread or "cosmopolitan" distribution for sublittoral amphipods of the Southern Ocean was reported several times (see De Broyer et al. 2007, for complete distribution records of benthic, bentho-pelagic and pelagic species occurring in the Southern Ocean). In clarifying the taxonomic status of species previously considered cosmopolitan, this study - on the basis of significant material - contributes to establish step by step, a more refined view of the biogeography of the Southern Ocean, where the benthic amphipods present a high rate of endemism of $83 \%$ (De Broyer et al. 2007).

Among benthic sublittoral amphipods occurring in the Southern Ocean s.s. (i.e. south of the Antarctic Polar Front), there are at least 20 species that have been reported as widely distributed in other oceans but the taxonomic identification of all records remains to be carefully checked. This is the case i.a. of the amphilochid Gitanopsis squamosa Thomson, 1880; the dexaminid Polycheria antarctica (Stebbing, 1875); the epimeriid Uschakoviella echiniphora Gurjanova, 1955; the eusiroids Eusiroides crassi Stebbing, 1888, E. monoculoides (Haswell, 1879), Paramoera fissicauda Dana, 1852 and Schraderia serraticauda (Stebbing, 1888); the ischyrocerid Jassa "falcata" (a complex of species partly revised by Conlan 1990); the lysianassid Hippomedon kergueleni Miers, 1875; the phoxocephalids Heterophoxus videns K.H. Barnard, 1930, Pseudharpinia dentata Schellenberg, 1931, Cephalophoxoides kergueleni (Stebbing, 1888) and ?Paraphoxus pyripes K.H. Barnard, 1930; the sebid Seba saundersii Stebbing, 1875; the stegocephalid Pseudo vanhoeffeni (Schellenberg, 1926); the stilipedids Alexandrella dentata Chevreux, 1912a and A. subchelata Holman \& Watling, 1983a; the caprellids Caprellinoides tristanensis Stebbing, 1888 and Pseudoprotomina hedgpethi McCain \& Gray, 1971.

Among pelagic species, the following species recorded in Antarctic waters are considered panoceanic or widespread in at least two other oceans: the eusirids Stenopleura atlantica Stebbing, 1888, Cleonardo longipes Stebbing, 1888 and Harcledo curvidactyla Pirlot, 1929; the cyphocaridids Cyphocaris anonyx Boeck, 1871, C. faurei K.H. Barnard, 1916 and C. richardi Chevreux, 1905; the pardaliscids Halice macronyx (Stebbing, 1888) and H. secunda (Stebbing, 1888); the stegocephalids Parandania boecki (Stebbing, 1888) and P. gigantea (Stebbing, 1883).

On the other hand, many deep-sea benthic or benthopelagic species are known to have geographic distributions encompassing several oceans (e.g. Brandt et al. 2012). 
Recent molecular studies demonstrated that many species considered widespread or cosmopolitan on the basis of morphological criteria were in fact composed of several cryptic species. A particularly demonstrative case is the combined molecular and morphological analysis conducted by Havermans et al. (2013) on Eurythenes gryllus (Lichtenstein, 1822), a cosmopolitan deep-sea benthopelagic lysianassoid, which appears to represent in fact a complex of 9 putative species-level clades, with more restricted distribution.

For the Antarctic amphipod fauna, these and the present results emphasize the need to re-examine morphologically in more details and to test with molecular methods the validity of some widespread distributed species, in particular the so-called panoceanic species.

\section{Acknowledgements}

This is contribution $n^{\circ} 85$ to the Census of Antarctic Marine Life and ANDEEP publication $n^{\circ} 183$. The first author was supported by two Synthesis grants from the European Commission during her visits to RBINS in Brussels. The second author was partly supported by the Scientific Research Programme on the Antarctic of the Belgian Federal Science Policy. The authors gratefully thank the various collectors in the difficult Antarctic conditions as well as the colleagues and collection managers who kindly provided material for this study: David Barnes (British Antarctic Survey, Cambridge, UK), Anna Jazdzewska (University of Łódź, Poland), Martin Rauschert (Alfred Wegener Institut, Bremerhaven, Germany), Kareen Schnabel (NIWA, Wellington, New Zealand), and Joanna Taylor (Victoria Museum, Melbourne, Australia). Anton Van de Putte (RBINS) kindly drafted the distribution maps.

\section{References}

Barnard J.L. 1972. The marine fauna of New Zealand: algae-living littoral Gammaridea (Crustacea Amphipoda). New Zealand Oceanographic Institute Memoirs 62, New Zealand Oceanographic Institute, Wellington.

Barnard J.L. 1974. Gammaridean Amphipoda of Australia. Part 2. Smithsonian Contributions to Zoology 139, Smithsonian Institution Press, Washington. http://dx.doi.org/10.5479/si.00810282.139

Barnard K.H. 1916. Contributions to the Crustacean Fauna of South Africa. 5. The Amphipoda: 105302. Annals of the South African Museum 15 (3), printed for the trustees of the South African Museum, London. http://dx.doi.org/10.5962/bhl.title.10646

Brandt A., Błażewicz-Paszkowycz M., Bamber R.N., Mühlenhardt-Siegel U., Malyutina M.V., Kaiser S., De Broyer C. \& Havermans C. 2012. Are there widespread peracarid species in the deep sea (Crustacea: Malacostraca)? Polish Polar Research 33 (2): 139-162. http://dx.doi.org/10.2478/v10183-012-0012-5

Chilton C. 1912. XXIII.-The Amphipoda of the Scottish National Antarctic Expedition. The Transactions of the Royal Society of Edinburgh 48 (2): 455-520. http://dx.doi.org/10.1017/S0080456800002957

Chilton C. 1921. Some New Zealand Amphipoda: No.2. Transactions of the New Zealand Institute 53: 220-234.

Coleman O. 2003. "Digital inking": how to make perfect line drawings on computers. Organisms Diversity \& Evolution 3 (4): 303-304. http://dx.doi.org/10.1078/1439-6092-00081

Coleman O. 2007. Acanthonotozomellidae, Amathillopsidae, Dikwidae, Epimeriidae, Iphimediidae, Ochlesidae and Vicmusiidae. In: De Broyer C. (ed.) Census of Antarctic Marine Life: Synopsis of the Amphipoda of the Southern Ocean. Vol. 2. Bulletin de l'Institut Royal des Sciences Naturelles de Belgique 77 (suppl. 2), Royal Belgian Institute of Natural Sciences, Brussels.

Coleman O. 2009. Drawing setae the digital way. Zoosystematics and Evolution 85 (2): 305-310. http:// dx.doi.org/10.1002/zoos.200900008 
Conlan K. 1990. Revision of the crustacean amphipod genus Jassa Leach (Corophioidea: Ischyroceridae). Revue canadienne de zoologie 68 (10): 2031-2075. http://dx.doi.org/10.1139/z90-288

Crowe S.E. 2006. A redescription of Leucothoe spinicarpa (Abildgaard, 1789) based on material from the North Atlantic (Amphipoda, Leucothoidae). Zootaxa 1170: 57-68.

De Broyer C. \& Danis B. 2011. How many species in the Southern Ocean? Towards a dynamic inventory of the Antarctic marine biodiversity. Deep-Sea Research II: Topical Studies in Oceanography 58 (1-2): 5-17. http://dx.doi.org/10.1016/j.dsr2.2010.10.007

De Broyer C., Lowry J.K., Jazdzewski K. \& Robert H. 2007. Catalogue of the Gammaridean and Corophiidean Amphipoda (Crustacea) of the Southern Ocean with distribution and ecological data. In: De Broyer C. (ed.) Census of Antarctic Marine Life: Synopsis of the Amphipoda of the Southern Ocean. Vol. 2. Bulletin de l'Institut Royal des Sciences Naturelles de Belgique 77 (suppl. 1), Royal Belgian Institute of Natural Sciences, Brussels.

Della Valle A. 1893. Gammarini del Golfo di Napoli. Fauna und Flora des Golfes von Neapel 20, R. Friedlander \& Sohn, Berlin. http://dx.doi.org/10.5962/bhl.title.3710

Gurjanova E. 1951. Amphipoda Gammaridea from the seas of the USSR and vicinity. Opredeliteli Faune SSSR, Zoologicheskii Institut Akademii Nauk SSSR 41. [in Russian]

Gutt J., Hosie G. \& Stoddart M. 2010. Marine life in the Antarctic. In: McIntyre A.D. (ed.) Life in the World's Oceans: 203-220. Wiley-Blackwell, Oxford. http://dx.doi.org/10.1002/9781444325508.ch11

Havermans C., Sonet G., d'Udekem d'Acoz C., Nagy Z.T., Martin P., Brix S., Riehl T., Agrawal S. \& Held C. 2013. Genetic and morphological divergences in the cosmopolitan deep-sea amphipod Eurythenes gryllus reveal a diverse abyss and a bipolar species. PLOS One 8 (9): e74218. http://dx.doi. org/10.1371/journal.pone.0074218

Holman H. \& Watling L. 1983. Amphipoda from the Southern Ocean: families Colomastigidae, Dexaminidae, Leucothoidae, Liljeborgiidae, and Sebidae. Biology of the Antarctic Seas. 13. Antarctic Research Series 38 (4): 215-262.

Horton T., Lowry J. \& De Broyer C. 2013. World Amphipoda Database. Available from http://www. marinespecies.org/amphipoda [accessed 19 Aug. 2013].

Krapp-Schickel T. \& Menioui M. 2005. Leucothoe species from Moroccan Atlantic coasts with redefinition of some species within the Leucothoe spinicarpa clade. Bollettino del Museo Civico di Storia Naturale di Verona. Botanica-Zoologia 29 : 63-83

Krapp-Schickel T. 2011. New antarctic stenothoids sensu lato (Amphipoda, Crustacea). European Journal of Taxonomy 2:1-17. http://dx.doi.org/10.5852/ejt.2011.2

Krapp-Schickel T. \& Vader W. 2012. Leucothoid and Maerid Amphipods (Crustacea) from deep regions of the North Atlantic. Helgoland Marine Research 67 (3): 383-396. http://dx.doi.org/10.1007/s10152$\underline{012-0330-3}$

Lowry J. \& Bullock S. 1976. Catalogue of the Marine Gammaridean Amphipoda of the Southern Ocean. Bulletin 16, Royal Society of New Zealand, Wellington.

Pfeffer G. 1888. Die Krebse von Südgeorgien nach der Ausbeute der Deutschen Station 1882-83. 2. Teil. Die Amphipoden. Jahrbuch der Hamburgischen Wissenschaftlichen Anstalten 5: 75-142.

Sars G.O. 1895. An account of the Crustacea of Norway with short descriptions and figures of all the species. Vol. 1. Amphipoda. Alb. Cammermeyer Forlag, Christiania \& Copenhagen. http://dx.doi. org/10.5962/bhl.title.1164 
Schiaparelli S., Danis B., Wadley V. \& Stoddart D.M. 2013. The Census of Antarctic Marine Life: the first available baseline for Antarctic marine biodiversity. In: Verde C. \& di Prisco G. (eds) Adaptation and Evolution in Marine Environments. Vol. 2. The impacts of Global Change on Biodiversity: 3-19. Springer, Berlin-Heidelberg. http://dx.doi.org/10.1007/978-3-642-27349-0_1

Sokolov S. \& Rintoul S.R. 2009. Circumpolar structure and distribution of the Antarctic Circumpolar Current fronts: 1. Mean circumpolar paths. Journal of Geophysical Research 114: C11018. http://dx.doi. org $/ 10.1029 / 2008 \mathrm{JC} 005108$

Stebbing T.R.R. 1906. Amphipoda. I. Gammaridea. Das Tierreich 21, Verlag von R. Friedländer und Sohn, Berlin. http://dx.doi.org/10.5962/bhl.title.1224

Turner J., Bindschadler R., Convey P., di Prisco G., Fahrbach E., Gutt J., Hodgson D., Mayewski P. \& Summerhayes C. 2009. Antarctic Climate Change and the Environment. Scientific Committee on Antarctic Research, Cambridge.

Verde C. \& di Prisco G. 2013. Adaptation and Evolution in Marine Environments. Vol. 2. The impacts of Global Change on Biodiversity. Springer, Berlin-Heidelberg.

Walker A.O. 1907. Crustacea. III. Amphipoda . In: National Antarctic Expedition 1901-1904. Natural history. Vol. III. Zoology and botany: 1-38. British Museum, London.

Walker A.O. 1909. Amphipoda Gammaridea from the Indian Ocean, British East Africa and the Red Sea. Transactions of the Linnean Society of London. Series 2: Zoology 12 (4): 323-344. http://dx.doi. org/10.1111/j.1096-3642.1909.tb00145.x

Watling L. 1989. A classification system for crustacean setae based on the homology concept. In: Felgenhauer B.E., Watling L. \& Thistle A.B. (eds) Functional morphology of feeding and grooming in Crustacea: 15-26. Balkema, Rotterdam.

White K.N. \& Thomas J.D. 2009. Leucothoidae. In: Lowry J.K. \& Myers A.A. (eds) Amphipoda (Crustacea, Peracarida) of the Great Barrier Reef, Australia: 494-555. Zootaxa 2260.

Zeidler W. \& De Broyer C. 2009. Catalogue of the Hyperiidean Amphipoda (Crustacea) of the Southern Ocean with distribution and ecological data. In: De Broyer C. (ed.) Census of Antarctic Marine Life. Synopsis of the Amphipoda of the Southern Ocean 3: 1-103. Bulletin de l'Institut Royal des Sciences Naturelles de Belgique 79 (suppl.1), Royal Belgian Institute of Natural Sciences, Brussels.

Manuscript received: 29 August 2013

Manuscript accepted: 26 February 2014

Published on: 15 April 2014

Topic editor: Rudy Jocqué

Desk editor: Charlotte Thionois

Printed versions of all papers are also deposited in the libraries of the institutes that are members of the EJT consortium: Muséum National d'Histoire Naturelle, Paris, France; Botanic Garden Meise, Belgium; Royal Museum for Central Africa, Tervuren, Belgium; Natural History Museum, London, United Kingdom; Royal Belgian Institute of Natural Sciences, Brussels, Belgium; Natural History Museum of Denmark, Copenhagen, Denmark. 